Monika Agopsowicz

(D) https://orcid.org/0000-0003-2857-7824

Fundacja Kultury i Dziedzictwa Ormian Polskich

\title{
ORMIANIE KAMIENIECCY W OSTATNIEJ ĆWIERCI XVII WIEKU \\ UZUPEŁNIENIE SPISU IMIENNEGO NA PODSTAWIE KOLEJNYCH ŹRÓDEŁ
}

\begin{abstract}
Abstrakt: Autorka wykorzystuje kolejne źródła historyczne, aby uzupełnić dane o Ormianach mieszkających w Kamieńcu Podolskim przed inwazją turecką w 1672 roku i zaraz po odzyskaniu miasta przez Polskę w 1700 roku. Wspomniane źródła to: księgi sądu ormiańskiego Kamieńca Podolskiego z lat 1651-1663; regestra wywiezionych z Kamieńca aparatów kościelnych i ich stopniowa sprzedaż; tureckie spisy ludności Kamieńca Podolskiego, w tym Ormian, z 1681 roku.
\end{abstract}

Słowa kluczowe: Ormianie polscy, Kamieniec Podolski, Filibe (Płowdiw), Sozopol, Andrzej Modrzejowski, Jan Romaszkiewicz, relacje polsko-tureckie, XVII wiek

W szóstym roczniku czasopisma „Lehahayer” podjęłam próbę rekonstrukcji imiennego spisu Ormian w Kamieńcu Podolskim od około 1672 roku do początków XVIII wieku' ${ }^{1}$. Podstawą zidentyfikowania 426 osób były akta ormiańskiego sądu konsystorskiego ze Lwowa, w których zamieszczano imiona i nazwiska Ormian wyrzuconych przez Turków w 1674 roku z Kamieńca Podolskiego i przesiedlonych na teren obecnej Bułgarii. Wygnańcy zorganizowani byli na wzór swej macierzystej gminy, a dla przeżycia i utrzymania się dysponowali dobrami należącymi do swego Kościoła. Sąd lwowski rozliczał ich z tych pożyczek po powrocie do ojczyzny, w latach 1685-1690².

${ }^{1}$ M. Agopsowicz, Ormianie kamienieccy w ostatniej ćwierci XVII wieku-próba rekonstrukcji spisu imiennego, „Lehahayer”, 6, 2019, s. 5-69.

2 Biblioteka Zakładu Narodowego im. Ossolińskich (dalej: BZNiO) we Wrocławiu: sygn. 1732/II, Protocollum actorum consistorii archiep[iscop] atus Leopolien[sis] nationis Armenae 
Już w kilka miesięcy po ukazaniu się artykułu zapoznałam się z trzema niezwykle ważnymi, a nieznanymi mi wcześniej, źródłami historycznymi. Niewątpliwie najistotniejsze z nich to księgi sądu ormiańskiego z Kamieńca Podolskiego z interesującego mnie okresu, znajdujące się w Centralnym Państwowym Historycznym Archiwum Ukrainy w Kijowie. Zostały one opublikowane na stronie internetowej tego archiwum, dzięki czemu stały się wreszcie dostępne. Te z nich, które okazały się przydatne, obejmują lata 1651-1663³. Następna po 1663 roku zachowana ormiańska księga sądowa z Kamieńca zaczyna się dopiero w 1701 roku. Wykorzystałam głównie zapisy w języku polskim. Wydaje się, że w zapisach sądowych język polski stosowany był wtedy, gdy co najmniej jedna ze stron nie znała kipczackiego. Na przykład wiele spraw sądowych z udziałem członków rodziny Piramowiczów (Pirumowiczów) było zapisywanych po polsku. Niektóre uzupełnienia zaczerpnęłam z przekładów zapisów kipczackich z tych ksiąg, dokonanych przez Ołeksandra Harkawcia ${ }^{4}$. Za wskazanie drugiego chronologicznego źródła, odnoszącego się bezpośrednio do exodusu Ormian z Kamieńca Podolskiego, dziękuję Andrzejowi A. Ziębie. Jest to sprawozdanie z rozporządzania przez wygnańców cennymi przedmiotami kultu wywiezionymi z miasta oraz gotówką, sporządzone pod dyktando ormiańskiego wójta Kamieńca, Grzegorza Miłkiewicza, w Filipopolis (Filibe, obecnie - Płowdiw) najpewniej we wrześniu $1677 \mathrm{roku}^{5}$. Możliwe też, że to, co spisane zostało w tym okresie, przepisane było później „na czysto” już we Lwowie, przed 1683 rokiem, w którym Miłkiewicz zmarł. Trzecie chronologicznie źródło to spis Ormian kamienieckich dokonany przez administrację osmańską około roku 1681, wydany wraz z całym defterem (rejestrem) podolskim przez Dariusza Kołodziejczyka ${ }^{6}$. W spisie tym występuje 89 osób, najczęściej wymienionych z imienia i patronimiku. Identyfikacja tych osób okazała się niejednoznaczna. Można przypuszczać, że byli to Ormianie

tam sub administratione Re[vere]nd[issi]mi D[omi]ni Deodati Nersessovicii episcopi Traianopolitanensis quam sub felici introductione Ilustr[issi]mi ac Re[vere]nd[issi]mi D[omi]ni Vartani Hunaniani Dei et Ap[osto]licae Sedis gratia archiep[iscop]i Leopoliensis nationis eiusdem Armenae formatum [1684-1699].

${ }^{3}$ Центральний державний історичний архів України, м.Київ (dalej ЦДІАУ): f. 39, op. 1, spr. 41, 42, 158.

${ }^{4}$ А. Н. Гаркавец, Кыпчакское письменное наследие, Каталоги и тексты памятников армянским письмом, t. Украина, Алматы 2002, s. 871-954.

5 Biblioteka Narodowa w Warszawie (dalej: BN): sygn. Rps Akc. 12904, Wygnańcy ormiańscy Kamieńca Podolskiego w Turcji (1675-1677). (Regestra wywiezionych z Kamieńca aparatów kościelnych i ich stopniowa sprzedaż) [dopiski ołówkiem:] na utrzymanie wygnańców; nad słowem aparatów jest dopisane ołówkiem słowo: skarbów. Dziękuję pracownikom Biblioteki Narodowej za sporządzenie kopii tego dokumentu mimo trudności, które musieli pokonać.

${ }^{6}$ D. Kołodziejczyk, The Ottoman Survey Register of Podolia (ca. 1681). Defter-i Mufassal-i Eyalet-i Kamaniçe, 1, Cambridge, Mass. 2004, s. 87-90. 
w jakiejś części (większości?) przybyli do Kamieńca wraz z Turkami. Należy też wspomnieć, że w 2020 roku ukazała się drukiem Metryka katedry ormiańskiej we Lwowie za lata 1635-17327. Wykorzystywałam ją dzięki uprzejmości wydawcy, Krzysztofa Stopki, któremu także dziękuję za cenne uzupełnienia spisu jeszcze przed publikacją poprzedniego artykułu („Lehahayer”, 6). Teraz, gdy Metryka została już opatrzona indeksem osobowym, udało się zidentyfikować w niej jeszcze więcej mieszkańców Kamieńca.

Sprawozdaniu Grzegorza Miłkiewicza, jako odnoszącemu się bezpośrednio do sprawy wygnańców, należy poświęcić więcej uwagi. Wszystkich stron tego rękopisu jest 38, z tego 33 zapisane. Tytuł nadany został najpewniej później, niż spisana została treść, natomiast na stronie 2 jest dający do myślenia zapis oryginalny, tyle że innym charakterem pisma niż reszta:

Rejestrz wywiez[i]onych Apparatów z Kamienca Roku 1675. Dnia 26. Pazdziernika do Zuzopola [Sozopola], a z tamtąd do Philippopola, y tych dyspozycia albo dystrybuta z podpisem niektorych [ex] Communitt[ate] [ze wspólnoty $]^{8}$.

Wydaje się, że zamiast roku 1675 we wpisie tym powinien figurować 1674 , ponieważ z dotychczas zebranych przesłanek źródłowych wynika, że Ormianie wyjechali z Kamieńca przed 23 października 1674 roku9. Wzmiankowany dzień 26 października mógł być tu zapisany według kalendarza gregoriańskiego, co dawałoby datę 16 października według kalendarza juliańskiego. Ponadto, jak wynika $\mathrm{z}$ dalszej treści omawianego tu dokumentu, Ormianie przenieśli się z Sozopola do Filibe między kwietniem a lipcem 1675 roku. W październiku 1675 roku byli już w Filibe, które notabene zaczęli opuszczać we wrześniu 1677 roku, kierując się do Polski.

W tym miejscu potrzebna jest krótka wzmianka o różnicach datowania. W dokumencie jest około 30 dat zapisywanych na kilka sposobów: 1) równocześnie dwie daty z powołaniem się na stary i nowy kalendarz z podanym dniem tygodnia; różnica między tymi datami to dziesięć dni; 2) jedna data z odnośnikiem, z którego jest kalendarza, z podanym dniem tygodnia albo nie; 3 ) jedna data i brak odniesienia do kalendarza i do dnia tygodnia. Niektóre dokumenty nie są w ogóle datowane. Ponieważ w wielu wypadkach te same fragmenty sprawozdania będą dotyczyły różnych osób umieszczonych w spisie imiennym, każdy taki fragment oznaczam zapisem skrótowym „Dokument nr” od 1 do 18.

${ }^{7}$ Metryka katedry ormiańskiej we Lwowie za lata 1635-1732 w opracowaniu Krzysztofa Stopki (część kipczacka) i Marcina Łukasza Majewskiego (część polska i łacińska), seria: Pomniki dziejowe Ormian polskich, 3, Kraków 2020.

8 BN: sygn. Rps Akc. 12904, k. 2.

9 J. Woliński, Przyczynki źródłowe do kampanii 1674 r., „Przegląd Historyczno-Wojskowy", 6, 1933, s. 89. 
Rękopis rozpoczyna się wstępem przedstawiającym potrzebę spisania dziejów wygnania z Kamieńca:

W Imie Panskie Amen.

Ponieważ wszelakie na tym padole żyiących ludzi dzieła, tak za powodem Cnoty ku chwale Maiestatu Boskiego zmierzaiące, iako też przeciwnym sposobem z Obrazą iego Swiątobliwosci sprawowane, zwykli Dzieopisowie pamiątkę onych pismem Connotować, y one potomnym podawac wiekom (gdyż y zywot nasz ktorym się zaszczyczamy [odczyt słowa niepewny] iest krotki) zkąd niemałą tak Cnotę kochaiący, iako y inni nawracaiący się ludzie do poprawy żywota, z czytania takowych Chronik uznawaią obradę [tj. radość], dlategoż y ia niegodny Grzegorz Miłkiewicz niegdy alumnus [tj. wychowanek] Miasta Kamienca, post tot exant latos laboris et tribulationes perpessos [po tak wielu różnorodnych zajęciach i przebytych cierpieniach], przepędziwszy lata moie ad annum 71. we wselakich odmiennosciach swiatowych, z pewnych respektow zycząc, aby Connotatiae przezemnie infra recensendorum [poniżej spisane], posteris [potomkom] narodu naszego Ormianskiego, per manus [ręcznie] podana bydz mogła, tak to wszystko wyłuszczyc chciał bym ${ }^{10}$.

Miłkiewicz wzmiankował dalej pospieszne opuszczenie Kamieńca (Ormianie mieli na to dwa dni), zakopanie przed wyjazdem większości przedmiotów liturgicznych (,,wszelakie dobra y ornamenta kosciołow ormianskich kamienieckich"11) oraz zabranie pozostałych rzeczy, a następnie ich spisywanie w obecności od kilku do kilkudziesięciu przedstawicieli wspólnoty. Jak pokazały źródła już wykorzystane w poprzednim artykule i te obecnie omawiane, celem spisów było rozliczenie się z zabranego z Kamieńca mienia przed księżmi, mniszkami i całą wspólnotą, której przedstawiciele sprawowali pieczę nad dobrami kościelnymi, oraz przed własnymi sumieniami. Przedmioty te, możliwie najmniej naruszone, miały z czasem powrócić albo być zwrócone w postaci równoważnej gotówki do poszczególnych kościołów i do klasztoru mniszek. Jeśli decydowano się na spieniężanie rzeczy, to tylko dla pilnych bytowych potrzeb wspólnoty i dla opłacania ważnych spraw $\mathrm{u}$ władz tureckich.

Miłkiewicz we wstępie wspominał także swego brata, wójta Kuryłę, zmarłego w Sozopolu 25 lutego / 7 marca 1675 roku, jako z urzędu odpowiedzialnego za wywiezione dobra kościelne. Po śmierci Kuryły powstała potrzeba sporządzenia inwentarza ,przy zupełnym nie tyl[k]o urzędowych osob, tam się znayduiących, ale y pospolitego ludu zgromadzeniu, oraz y z kapłanami, ktorzy takowy skrypt rękami własnemi (iako się niży będzie verifikowało) podpisawszy do kilkudziesiąt osób ratifikowali" ${ }^{12}$. Miłkiewicz skarżył się w zawiły i niejasny sposób, że

\footnotetext{
10 BN: sygn. Rps Akc. 12904, k. 3.

11 Ibidem.

12 Ibidem.
} 
starsi i pospólstwo (Rada Czterdziestu Mężów) wywierali na nim jakiś nacisk (pod którym zapewne ustąpił), by przejął funkcję po nieżyjącym bracie, i zaraz potem zapewniał, że wszystkie spisy (przedmiotów i wydatków), przetłumaczone $\mathrm{z}$ języka ormiańskiego i spisane przez ormiańskiego pisarza urzędowego, nie zawierają błędów.

[A] na ostatek gdyby tylko czas mi pozwolił durante vita etiam juramento comprobare vellem, a in defectu propria morte hanc declarationem ad normam testamenti confirmandam censeri [za życia także chciałbym przysięgą potwierdzić, a w przypadku mojej śmierci ta deklaracja ma być uznana za potwierdzoną według norm testamentu $]^{13}$.

W dalszej części dokumentu przedstawiane były zestawienia przedmiotów i pieniędzy, i zaraz pod nimi wymieniano co, na jakie cele i kiedy zostało z danego zestawienia wydatkowane. Trzy ostatnie strony są podsumowaniem całości. Wydaje się zasadne przestawienie kolejności tych zapisek i pokazanie ich w porządku chronologicznym, by poznać działania kamieńczan na wygnaniu.

W Sozopolu 6 lutego 1675 roku (prawdopodobnie według starego kalendarza, czyli 16 lutego według nowego), w obecności dziesięciu przedstawicieli wspólnoty, sporządzono długi, bo niemal czterostronicowy, spis rzeczy (i ich finansową wartość „tak we złocie, iako y w perłach będących”"14), pochodzących z dwóch ormiańskich kościołów w Kamieńcu: św. Mikołaja i Przenajświętszej Panny Kamienieckiej. Znajdujemy wśród nich m.in.: łańcuchy, pierścienie, naszyjniki, noszenia, zgardy (rodzaj naszyjnika), perfumy, nauszki, krzyżyki, zausznice, manele i maneliczki, sznury pereł, korali, dukaty. Były to drogocenne dary ofiarowywane przez wiernych do kościołów (Dokument $\mathrm{nr} 1^{15}$ ).

25 lutego / 7 marca (1675 roku) w Sozopolu trzydzieści osób - „kapłani, starsi z rady, mężowie y pospólstwo [członkowie Rady Czterdziestu Mężów] ${ }^{16 ”}$ delegowali do Porty: Jana Bobrykiewicza, Zachariasza Jakubowicza, Zachariasza Emirowicza i Bernata Isajowicza, aby uzyskać pozwolenie na przeniesienie się całej wspólnoty z Sozopola do Janpola (prawdopodobnie Iwanowo koło Ruse

13 Ibidem, k. 3v.

${ }^{14}$ Ibidem, k. 6.

15 Ibidem, k. 6-8.

${ }^{16}$ W cytowanych dokumentach określenia „pospólstwo” i „mężowie” pojawiają się obok siebie, a niekiedy ta sama osoba reprezentuje jedną i drugą instancję. Stąd wydaje się, że Rada Czterdziestu Mężów i Pospólstwo (Communitas), które w miastach polskich były dwoma rozmaitymi w składzie reprezentacjami tej samej grupy społecznej, to jest ogółu mieszczaństwa, przy czym rola pierwszej z nich zanikała w wieku XVII na rzecz drugiej (czyli, że doszło tam do ewolucji w istocie tylko nomenklaturowej), nie miały swych odpowiedników w ormiańskiej gminie Kamieńca Podolskiego, gdzie faktycznie istniała tylko Rada Czterdziestu Mężów, określana czasem właśnie jako „mężowie i pospólstwo”. Dlatego w spisie mieszkańców zamieszczonym poniżej ujednolicono zapis źródłowy na rzecz Rady Czterdziestu Mężów. 
w Bułgarii, ok. 280 km na północny zachód od Sozopola) (Dokument nr $2^{17}$ ). Przyczyną, dla której Ormianie chcieli za wszelką cenę wynieść się z Sozopola, a o której przypomniano przed sądem konsystorskim we Lwowie, był brak warunków odpowiednich do życia, gdyż miasto „było puste, żadnego domu do mieszkania nie mające, w którem byli ludzie powietrzem wymarli" ${ }^{18}$. W tym miejscu dokumentu pojawia się numer odnośnika (3), który był szczegółową instrukcją dla delegatów. Takich numerów odnośników w całym dokumencie jest 16, od numeru 3 do 18, ale ich treść nie jest znana. Następnym chronologicznie dokumentem, który dotrwał do naszych czasów, jest trzystronicowy inwentarz dóbr kościelnych przejętych przez społeczność kamienieckich Ormian dzień po śmierci i pogrzebie wójta Kuryły Miłkiewicza w Sozopolu 26 lutego / 9 marca 1675 roku (Dokument $\mathrm{nr} 3^{19}$ ).

My Chodzik Hołubowicz, Murath Seferowicz, Jan Bobrykiewicz, Zachariasz Jakubowicz przysięgli Prawa Ormianskiego niegdy Kamien[ieccy] do wiadomosci podaiemy wszem wobec, komu by otym wiedziec było potrzeba, tak tu będącym Natię Naszey Ormianskię osobom, iako tez y nie znayduiącym się tu naten czas, iż my upatruiąc to, iako niespodzianie z tego swiata zszedł godney pamięci Pan Kuryło Miłkiewicz woyt nasz, a uważaiąc, aby względem apparatów koscielnych przy tymze Panu Woycie in sequestro [w tymczasowym zarządzie] zostaiących, z Kamienca zas tak przez Onegoż, iako y przez nas wywiezionych do dnia dzisięszego, iaka trudnosc, albo wątpliwosc między Natią Naszą nie urosła, zarazem nazaiutrz po pogrzebie zeszlismy do domu mianowanego Pana Woyta, gdzie zazwawszy [tj. zawezwawszy] do boku naszego obecnie będących tak kapłanow, to iest wielebnych xiędza Michała Michałowicza, xiędza Zachariasza Owanisowicza, y xiędza Stephana Balickiego, iako y z mężow czterdziestu y z pospolstwa znayduiących się osob, naimie sław[etnych] Zachariasza Seferowicza, Awgustina Miłkiewicza, Krzysztopha Balcerowicza, Mikołaia Hanesowicza, Zachariasza Asłan Emirowicza, Grzegorza Krzysztopha Głowackiego, Krzysztopha Warteris Dryngaczowicza, Donowaka Theodorowicza, Krzysztopha Toros Kierekięszowicza, Mikołaia Bekieszowicza, Owanka Stephanowicza, Gabriela Barthoszewicza, Krzysztopha Seferowicza, Bogdana Bogdanowicza, Kirkora Milkonowicza, Bogdana Szymona Pirzady zięcia, Serhia Murathowicza, Kirkora Nimickiego, Hanesa Bekięszowego zięcia u[t] u[ltra] [i więcej] takowe apparaty poiednemu appertissime in praesentia [wyraźnie w obecności] wszystkich zinwentowalismy ${ }^{20}$.

17 BN: sygn. Rps Akc. 12904, k. 8.

18 S. Barącz, Żywoty sławnych Ormian w Polsce, Lwów 1856, s. 418.

19 BN: sygn. Rps Akc. 12904, k. 3v-5, 8.

${ }^{20}$ Ibidem, k. 3v. 
Początek spisu stanowią najcenniejsze przedmioty, takie jak: „korony na obrazach będące”, głównie „pani Jakubowey pamiątki”, „infuła biskupia DerAndriaszowska perłami y ferytami sadzona”, dwie srebrne monstrancje ,pierwsza p. Beznosego złocista zupełna [...], druga, Tatułowicza Warterisa biała ztluczona”, krzyże, 13 kielichów z 15 patenami, lichtarze, trybularze, lampa. Dalej: „para tablic z Ewangeliey oddartych z krzyżykami i tabliczkami przybitemi. Ewangeliey xiąg dwie wielkich, z małemi krzyżykami przybitemi”. Ponadto: około 30 ornatów, opisanych jak ten: „Ornat Bohosowski złotogłowiu białego, krzyz $\mathrm{w}$ tabliczki in $\mathrm{N}^{\circ}$ [w liczbie] 59, $\mathrm{z}$ humarałem takze w tabliczki srebrne złoc[iste]. manipularze sadzone perłami, alba kitaykowa". Prócz ornatów - kapy, alby, efody, humerały, manipularze, korporały, antepedia, 14 sukienek do obrazów Maryi i 4 kitajowe zasłony do obrazów ${ }^{21}$.

Po zinwentaryzowaniu przedmiotów i ich spisaniu Murat Seferowicz, jako ekonom kościelny, przedstawił sprawozdanie finansowe „ab anno 1672 aż do dzisiadnia" (Dokument nr 4). Wśród wydatków Seferowicz wymieniał: 70 talarów lewkowych pożyczonych zakładnikom lwowskim przetrzymywanym przez Turków w Kamieńcu, zwroty pożyczonych pieniędzy i

Paszy homagium lew[kowych] 72 na Baieram [tj. Kurban Bajram], item [a także] dołozono do 600 lewkowych Paszy danych (dla nie bytnych Ormian Kamien[ieckich] w Polszcze się bawiących [tj. przebywających] $\mathrm{z}$ udania Turkow) zosobna lewkowych $80^{22}$.

Ze spisanych przedmiotów odłożono kilkanaście dla sprawowania posługi liturgicznej, resztę rzeczy zapakowano i związano „we dwa węzły, y w ieden sepet [koszyk $\left.{ }^{23}\right]$, tak że y w skrzyneczkę" i każdy powierzono „pod pieczęciami” po dwóm Ormianom, czyli w sumie ośmiu osobom (Dokument nr 5) 24. Tak miało być do czasu, gdy nastąpi spotkanie z pozostałą częścią wspólnoty, rozproszoną jak okazuje się z dalszej części dokumentu - w Burgas i Konstantynopolu. Pod inwentarzem i sprawozdaniem podpisało się osiemnastu Ormian, w tym trzech księży i Zachariasz Seferowicz „,na tenczas uproszony director”, jako jedyny wymieniony z funkcji.

Ostatni zapis dokonany w Sozopolu pochodzi z 31 marca / 10 kwietnia 1675 roku i rozlicza przed ,tu będącym w Zuzupolu, iako y w Bergazie [Burgas] y w Constantinopolu zostaiącym braciom" powracających z dwóch miejsc: z Adrianopola, którzy wcześniej musieli zostać wydelegowani dla spieniężenia dóbr,

${ }^{21}$ Ibidem, k. 3v-4v.

${ }^{22}$ Ibidem, k. 5-5v.

${ }^{23}$ BZNiO: sygn. 1732/II, Protocollum actorum consistorii, k. 31v - „koszyk ieden mały alias sepet".

${ }^{24}$ BN: sygn. Rps Akc. 12904, k. 5v. 
i z Janpola, dokąd udali się na rekonesans (Dokument $\mathrm{nr}$ 6) ${ }^{25}$. Nie jest powiedziane, co uczyniono z gotówką pozostałą po pokryciu kosztów podróży.

Następny zapis pochodzi z Filibe, z czego wynika, że Ormianie nie przenieśli się do Janpola, a uzyskali zgodę na zamieszkanie w Filibe. 1 lipca 1675 roku przedstawiciele całej wspólnoty - księża, starsi („officialistowie”), deputowani z grona Rady Czterdziestu Mężów - postanowili wyasygnować z sepetu pieniądze „na wyprawę do porty” i przekazać resztę zawartości sepetu oraz dwa węzły pod opiekę ks. Michała Michałowicza (Dokument nr 7) ${ }^{26}$.

2 lipca 1675 roku (nie wiadomo według którego kalendarza) Ormianie wysłali kolejną delegację do Porty (Zachariasz Jakubowicz, Zachariasz Seferowicz, Krzysztof Balcerowicz i Jakub Bohosowicz) (Dokument nr 8) ${ }^{27}$ :

aby supplikowali Cessarza o mięsce na koscioł, nie zycząc sobie nieprzyiazni z Grekami [tj. prawosławnymi, którzy mieli w Filibe osiem kościołów], gdyby ich koscioł nam dac miano; druga o libertatię na kilka lat od pogłownego prosić y na przekupowanie [handel] bez przeszkody od cechowych ludzi tamecznych; trzecia, ieżeli pas wolny będzie do Kamienca o pozwolenie na pewne osoby aby tam zaiachawszy dobra swoie pozostałe spienięzyc mogli, a potym się wrocili do zon y dziatek.

Delegatom dano kolejne rzeczy do spieniężenia: infułę biskupią, monstrancję Beznosowską, wielki krzyż, dwadzieścia koron do obrazów, osiem krzyży, stary trybularz, cztery kielichy z patenami, pukle (?) z ornatu, kapę z albą i manipularzami, antepedium, kilka ornatów i humerał perłowy. Po ponad miesiącu delegaci przedstawili rachunki. Są to rozliczenia finansowe, ale nie ma sprawozdań z rezultatów misji. Zarówno ze wspomnianych już rozpraw przed sądem konsystorskim, jak i wzmianek w dalszej treści omawianego tu dokumentu wynika, że Ormianie otrzymali kościół w Filibe, zwolnienie z podatku i zgodę na wyjazd „braci” do Kamieńca. Nie wiadomo, czy dostali pozwolenie na handel. Pojawia się natomiast nazwisko dobroczyńcy z Konstantynopola, Ormianina, Abro Czelebiego $(† 1675 / 1676)$, który najpierw pod zastaw przywiezionych przez Ormian przedmiotów dał 500 talarów lewkowych na remont budynku kościoła, a potem zwrócił wszystkie rzeczy, nie żądając nic w zamian, ponieważ ,na się bierze

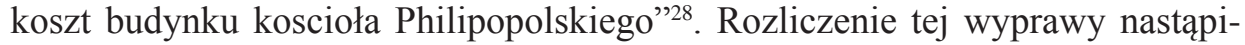
ło 16 sierpnia 1675 roku (nie wiadomo według którego kalendarza) (Dokument nr 9). W remoncie zrujnowanego kościoła uczestniczyli Ormianie kamienieccy, ale też perscy i lokalni, z Filibe. O tych ostatnich wspominał Symeon Lechacy w 1611 roku, że będąc w tym mieście, stwierdził obecność stu ormiańskich ro-

${ }^{25}$ Ibidem, k. 8-8v.

${ }^{26}$ Ibidem, k. 6.

27 Ibidem, k. 9.

${ }^{28}$ Ibidem, k. 9-10. 
dzin. W 1665 roku ta liczba musiała być nadal wysoka, skoro Filibe odwiedzał patriarcha Egiazar Ajntabcy ${ }^{29}$.

8 listopada / 18 listopada 1675 roku wysyłana została do Konstantynopola kolejna delegacja: ks. Michał Dermichałowicz, Donowak Theodorowicz i Grzegorz Serhiowicz. Głównym celem wyjazdu było pozyskanie funduszy na remont kościoła (Dokument nr 10). Miano też prosić Abrego Czelebiego o spieniężenie pozostawionych u niego rzeczy „za staraniem jego faktorów”, oddanie mu pożyczonych 500 talarów, zwrócenie 200 talarów Theodorowiczowi. Na sprzedaż przeznaczono tym razem: „9 złotych łancuchów y inne łomane złoto węgierskie y ieden dukat, to wszystko złoto ważące czerwonych [złotych] 202"30. Znów pojawia się odnośnik do nieznanego załącznika ósmego. Już po dwudziestu dniach delegaci rozliczyli się finansowo ze swej misji.

23 kwietnia / 3 maja 1676 roku tak duchowni, jak i świeccy przekazali część rzeczy z dwóch ormiańskich kościołów w Kamieńcu, spisanych 6 lutego 1675 roku, do spieniężenia w Adrianopolu (Edirne), odległym o ok. $180 \mathrm{~km}$ od Filibe. 12 maja / 22 maja 1676 roku delegaci Augustyn Miłkiewicz i Donowak Theodorowicz sprawozdawali, za jaką sumę sprzedali powierzone im przedmioty, w tym monstrancję Beznosowską. Odliczono koszty, m.in. na furmana, „za paciorki bursztynowe darowane władyce" i jałmużny dla dwóch osób (Dokument nr 11) ${ }^{31}$.

Z zapisu datowanego na 29 lipca / 8 sierpnia 1676 roku wynika, że Augustyn Miłkiewicz i Donowak Theodorowicz ponownie wysłani zostali do Konstantynopola „dla spieniężenia pewnych apparatów koscielnych” (Dokument nr 12) ${ }^{32}$. Wtedy sprzedano m.in. infułę biskupią (za 100 weneckich czerwonych), koronę do obrazu św. Szczepana, naszyjnik do obrazu Panny Najświętszej i humerały, ponadto łańcuchy, maneliczki, krzyżyki, sztuczki, lichtarze oraz należące do prowizorów szpitalnych: kubek, parę koszyczków, łyżki, pasek srebrny. Osobne spisy pereł zajmują prawie dwie strony. Część uzyskanych pieniędzy przeznaczono na borg (kredyt) dla tureckiego urzędnika. Zgromadzono w ten sposób 1000 talarów lewkowych, które rozdysponowano wśród wygnańców kamienieckich 11 sierpnia / 21 sierpnia 1676 roku. O tym, kto i ile otrzymał pożyczki z tych 1000 talarów, mówią adnotacje „(Filibe, 21 sierpnia 1676)” w spisie zamieszczonym w „Lehahayer", 6. Nikogo w tym spisie nie powinno brakować, ponieważ wsparcie otrzymało 121 osób i tyle jest wymienionych. Niemniej w obecnie omawianym dokumencie źródłowym pojawia się dwadzieścia jeden osób, które nie pasują do zamieszczonych już na liście. Wymieniam ich z adnotacją „Dokument nr 13”33.

29 В. Григорян, История армянских колоний Украины и Польши (армяне Подолии), Ереван 1980, s. 90.

${ }^{30}$ BN: sygn. Rps Akc. 12904, k. 9-9v.

31 Ibidem, k. 9v-10.

${ }^{32}$ Ibidem, k. 10v-11.

33 Ibidem, k. 12-13v. 
Tydzień po rozdaniu tysiąca talarów, do Porty wysłani zostali kolejni posłowie: Grzegorz Romaszkiewicz i Jakub Bohosowicz (Dokument nr 14), z następującą skargą:

Iz na słowo Hałył Paszy ruchome dobra zostawione w Kamiencu rozszarpane, y stoiące tez dobra poprzedane Ex Fisco. Druga[,] za emirem wysłanych braci do Kamienca pozabyano, tu znowu powietrzem do 200 ludzi wymarło, pozostali głod cierpią tesz. Trzecia[,] w Kamiencu zakopane dobra Koscielne wydac nie chcieli[;] tam będące kilka osob oznaymieło [...]. Czwarta [,] Graecy nie chcą nas w domach swych cierpiec musimy po domach Tureckich się sciskac. Piąta[,] o prolongatię libertaty supplikowac.

W listopadzie znowu spieniężono trochę dóbr, z których 16 talarów lewkowych przeznaczono na nieznaną bliżej sprawę Iwaszka Serhiowicza (Dokument $\mathrm{nr} 15)^{34}$.

28 listopada / 8 grudnia 1676 roku sporządzono dokument będący spisem dóbr kościelnych z informacją, które z nich wydawane były księżom i mniszkom jako zastawy (Dokument nr 16) ${ }^{35}$. Dokument ten cytowany był w aktach sądu biskupiego i wykorzystany został w artykule w „Lehahayer”, 6 .

Kolejna wyprawa delegatów do Porty miała cel inny od dotychczasowych. Wysłani 29 stycznia 1677 roku (nie wiadomo według którego kalendarza) Augustyn Miłkiewicz, Jakub Bohosowicz i Bogdan Jakubowicz mieli bezpośrednio u Turków starać się o prolongatę wolnizny podatkowej na dalsze cztery lata. Tyle bowiem przewidywali, że przyjdzie im najmniej spędzić jeszcze na wygnaniu. Delegaci mieli również przez Bogdana Seferowicza Spendowskiego podać suplikę do posła polskiego mniejszego, Andrzeja Modrzejowskiego, układającego się z Turkami, w której przedstawiali trzy prośby do rozmów z wezyrem. Po pierwsze, by mogli wyjechać i by wyposażono ich na drogę w podwody (,niektórym [...] o trzy mile isc niepodobna") za to, że cesarz przejął ich nieruchomości w Kamieńcu po ich wygnaniu. Po drugie, by tym Ormianom, którzy zostali w Kamieńcu, „wolno było wynosic się do kupy naszey”"36 razem z dobrami domowymi i kościelnymi. Po trzecie, by kościół w Filibe, zaniedbany uprzednio przez Greków (prawosławnych), a wolą sułtana przekazany Ormianom i przez nich restaurowany, ,przy tychże Ormianach Philippopolskich wiecznemi czasy bez przeszkody od Grekow zostawał" (Dokument nr 17) ${ }^{37}$. Wstęp supliki jest na tyle ciekawy, że warto go przytoczyć w całości:

\footnotetext{
${ }^{34}$ Ibidem, k. 13v.

35 Ibidem, k. 13v-14v.

${ }^{36}$ Ibidem, k. 15.

37 Ibidem, k. 14v-16.
} 
Wielmozny Msci Panie Posle Coronny, Nasz Wielce Msci Panie Patronie

Za okrucięstwa Thamerlanesa Przodkowie Nasi wyniosłszy się z pod Luny Otthomanskiey, ob liberu[m] exercitium Relligionis [dla wolności wyznawania religii], pod skrzydła Orła przeswitnego garnęli się, gdzie przez lat $\underline{300}$ et ultra [i więcej], iako w iakiey Palestynie miodem y mlekiem pływaiącey, z influentiey [z wpływem] Nieba przychilnego obfituiąc, z ręki Naiaszięszych Krolow Polskich wszelakie libertates et praerogativas [wolności i prerogatywy] odbierali, y one nam następcom per manus [własnoręcznie] z dowodami integrae fidelitatis [całkowitej lojalności] podawali. Lat sziła przeszłych z tegoż Nieba, ale iuż zagniewanego występki nasze zciągnęły vindictam Divini numinis [boską zemstę], podawszy Nas iterum sub ditionem [znowu pod panowanie] teyże Luny Otthomanskiey z pewnemy Diplomatami circa possessione bonorum, eorumq[ue] pignorum [o posiadaniu dóbr i ich zastawów] do czasu krotkiego, a potym ex occasione [z powodu] Czyli alimentowania [zaopatrywania] przez nas synow coronnych w ciężkich okowach zostaiących, czyli z innych okazię [okazji] ac si perduellionis [jak oskarżenie o zdradę] z domniewania się, paena exily mulctati [karą wygnania pognębieni], nie znosne incommoda terra, maria[que] [niewygody lądem i morzem] podiąwszy, braci y sąsiadow, iednych nawalnosciami morskiemy pogrążonych, drugich srogim powietrzem [tj. zarazą] ziemią przywalonych oplakawszy, tu w te kraie macedonskie, czyli thrackie, w szczupłey bar$\mathrm{d}[\mathrm{z}] \mathrm{o}$ liczbie dostaliśmy się.

Toż Niebo teraz, spędziwszy Nebula iterum [znowu mgłę], nas zagrzewac iasnoscią swoią poczyna. Dowodem tego iest Oycowskie pieczołowanie Je[go] K[rólewskiej] M[osci] P[ana] N[aszego] M[iłościwego], który inter maioris importantis negotia [wśród ważniejszych spraw], conferuiąc nunciale munus [poselski obowiązek] W[asz]m[ośc]i N[aszemu] $\mathrm{M}$ [iłośiwemu] $\mathrm{P}$ [anu], nasze też eliberatią dexteritati [uwolnienie zręczności] W[asz]m[ości] N[aszego] M[iłościwego] P[ana] Committit [powierzył]. Zaprawdę palec to Boży sprawuię ręki sercami Monarchow kieruiącey. Tritum [zwykłym] to iest u naszego narodu y u innych wielu, że nuncius pro angelo censetur [poseł uważany jest za anioła]. Zaczynayże tedy takową funkcię swoią nie poselską, ale Anyelską, w modrey szacie Anyelskiey, cny M[o]sci Panie Modrzeiewski, a przykładem Zbawiciela jętcom [jeńcom] lymbusowym [Otchłani] ręki podaiącego, racz też y nam utrapionym dexterum porrigere [prawicę podać], iako bysmy godnemy się stali wynosząc się ztąd z Psalmistą Panskim zaspiewac In Exitu Izrael de Aegipto, domus Jacob de populo barbaro [Gdy Izrael wychodził z Egiptu, dom Jakuba od ludu obcego; Psalm 114], a potym przypłynąwszy do portu szczęsliwosci y gniazda Orła przeswitnego, progi Lubey Oyczyzny łzami naszemy oblewaiąc Te Deum Laudamus, te D[omi]num Confitemur [Ciebie, Boga, wysławiamy, Ciebie Panie wychwalamy] wykrzykali oraz przytym za dostoyięstwo Maiestatu Krola Pana, y wszystkich stanow 
$\mathrm{R}[z e c z y] \mathrm{P}[$ ospoli]tey y za długo fortunne zdrowie $\mathrm{W}$ [asz]m[ości] N[aszego] M[iłościwego] P[ana] Naywyzszego Pana błagali, [...], y nas napotym do dozywotnich usług swoich powabic raczysz.

W[asz]m[ości] N[aszego] M[iłościwego] P[ana] y Patrona Najnizszi podnożkowie Ormianie utrapieni Kam[ienieccy $]^{38}$.

Wysłani do Konstantynopola delegaci sprawozdali 1 marca / 11 marca 1677 roku, że sprzedali za 200 talarów lewkowych: kapę Hadziewiczowską, antepedium i albę kitajkową pani Seferowej, dwa humerały i trzy bogate ornaty. Odzyskali również 336 lewkowych od potomków Abrego Czelebiego, które przeznaczone były przez niego na kościół w Filibe. Z uzyskanej sumy opłacono m.in.: Mehmeta Agę (darowano mu sukno), jego sługę (dostał paciorki bursztynowe), pracujących przy remoncie kościoła (,tak Perskim Ormianom iako y Philippopolskim, y Kamienieckim”) oraz rzemieślników „od okien koscielnych szklanych” i wreszcie ,nagrodę” dla czausza spisującego kamieńczan (Dokument nr 18) ${ }^{39}$.

Niedługo później znów potrzebne były pieniądze i 11 kwietnia / 21 kwietnia 1677 roku wysłuchano relacji Jakuba Bohosowicza z dwóch misji do Adrianopola. Ze sprzedaży konia, ornatów, humerałów, oddanych przez tureckiego urzędnika pereł (wcześniej wziął je na kredyt) i tabliczki z ,ornata x. Janowego Lwowskiego" uzyskał 462 talary lewkowe i 100 asprów. Większość tych pieniędzy wykorzystano m.in. na: czausza, który miał wprowadzić poprawki w spisie kamieńczan, łapówkę daną w Adrianopolu na uwolnienie od podatku pogłównego, ,za gorzałkę darowaną pewnym osobom”, „od aktikowania wolności” (którego sensu można się domyślać) i aż 200 talarów „na Wielkanoc dane znowu pospolstwu" (Dokument nr 19) ${ }^{40}$.

Następne dwie strony są podsumowaniem wszystkich przychodów (3549 lewkowych i 35 asprów) ze sprzedaży dóbr obu kościołów kamienieckich z podziałem na: złoto, srebro, perły, ornaty i inne przedmioty. W notatce dodano, że w przychodach nie uwzględniono około 20 lewkowych, które uzyskano ze sprzedaży srebrnych krzyżyków i paciorków koralowych, bowiem od razu przeznaczono je na ,homagia znacznym osobom podczas Baieramu”41.

Kolejną stronę zajmują podsumowania wydatków. Wynika z nich, że potrzebujących ze wspólnoty wspomożono nie tylko wspomnianą już sumą 1000 talarów, ale także wcześniej, w Sozopolu - sumą 163 talarów, a po 11 sierpnia / 21 sierpnia 1676 roku jeszcze kilka razy na łączną sumę 414 lewkowych. Osobną kategorią wydatków były te ,na rózne potrzeby y poiazdy [wyjazdy] do Porty”. Spłacono długi zaciągnięte u zasobniejszych wygnańców, zwrócono koszty

\footnotetext{
38 Ibidem, k. 14v-15.

39 Ibidem, k. 15-15v.

${ }^{40}$ Ibidem, k. 16-16v.

41 Ibidem, k. 17.
} 
podróży (fura, konie, strawa, gospoda), wyliczono sumy wypłacone kałauzom (zapewne przewodnikom) i najętemu czeladnikowi, architektowi, a także „darunki”, w tym filipopolskiemu kadiemu „w sprawie pogłownego tak u Porty, iako y w Philippopolim"42. Kilka pozycji to wydatki, które wykazane są w nieznanych nam załącznikach.

Ostatnie zdanie dokumentu wydaje się świadczyć o tym, że Filibe opuszczano w co najmniej dwóch grupach. Jedna wyjechała ze starszyzną przed 24 września 1677 roku (według którego kalendarza, nie wiemy), a druga, której zostawiono jeszcze przedmioty na sprzedaż, już po tym dniu. Mniej staranny zapis sprawia wrażenie pośpiechu piszącego:

Notandum [należy zauważyć] iednak iz te wydatki przez starszy[z]nę ad diem circiter [do dnia około], 24. Septemb[ris] Anni 1677 odprawowały się, po ktorych odiezdzie z Philippopola w reszcie zostaiące apparaty y inne sprzęty, iako się obrociły da się widziec napotym ${ }^{43}$.

Ormianie zapewnili sobie pozwolenie na opuszczenie Filibe jeszcze za poselstwa Modrzejewskiego. Następny poseł polski, tzw. wielki, Jan Gniński, miał domagać się u Porty, by „ludzi wszystkich, zaprowadzonych z Kamieńca za Dunaj, do granicy polskiej odprowadzić i puścić wolno" ${ }^{44}$. Ratyfikacja pokoju żurawińskiego w kwietniu 1678 roku w artykule 13 mówiła o tym, że „mieszkańcy fortecy Kamieńca, który po wzięciu tej fortecy byli z niej wygnani, będą mieli wolność powrócić do swojej ojczyzny i żyć na Podolu, jeśli im się podoba”. Ormianie kamienieccy z Filibe byli już wtedy od około pół roku w Polsce.

Podsumujmy: Ormianie opuszczali Kamieniec jako zorganizowana grupa kilkuset osób z wójtem i oficjalistami na czele. Mieli dwa dni na spakowanie się i zabrali część dóbr kościelnych. Większość tych dóbr zostawili w Kamieńcu, ale zakopali je. $Z$ datacji dokumentów wynika, że dopłynęli do brzegu Morza Czarnego (nad Morze Marmara, czyli Białe, jak pisał ormiańskoapostolski biskup Mesrob w 1828 roku ${ }^{45}$, mogli dopłynąć ci, którzy zatrzymali się w Galacie koło Konstantynopola) i ulokowali się w wyludnionym zarazą Sozopolu przed początkiem lutego 1675 roku. Bardzo zależało im na tym, by wynieść się z tego miejsca i początkowo chcieli przenieść się do Janpola, gdzie nawet zrobiono rekonesans. Ostatecznie stanęło na Filipopolis (Filibe), dokąd przenieśli się w kwietniu, maju lub czerwcu 1675 roku. W Filibe zastali mieszkających tam Ormian, którzy nie

${ }^{42}$ Ibidem, k. 17v.

${ }^{43}$ Ibidem, k. 18.

44 J. Woliński, Materjały do rokowań polsko-tureckich r. 1676, „Przegląd Historyczny”, 29, 1930-1931, 2, s. 402

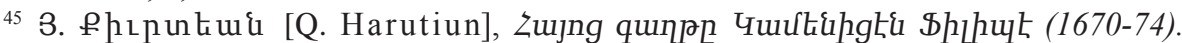

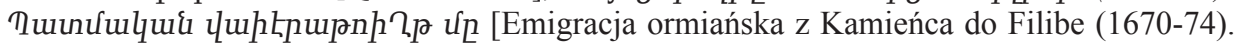
Zabytek historyczny], „Fuiquultzu” (Bazmaveb), 1927, 8-9, s. 237-239. 
mieli swojego kościoła. Skąd wzięli się „bracia” w Konstantynopolu (z okrętu, który wylądował w Galacie?) i w Burgas? W pewnym momencie przestaje się o nich mówić. Nie ma też mowy o tym, by zgromadzili się w Filibe.

Wygnańcy z Sozopola i Filibe kilkukrotnie wysyłali do Adrianopola i do Konstantynopola swoich delegatów na skargi, dla spieniężania przywiezionych z Kamieńca dóbr kościelnych, dla załatwiania zwolnień z podatków i uzyskania od wyznawców prawosławia jednego z kościołów w Filibe, wreszcie dla wyjednania zgody na przenosiny - najpierw z Sozopola, następnie do Polski (ta prośba kierowana była przez posła polskiego). Wiadomym jest, że dobrze znali miejsca (i ludzi), do których jeździli: Adrianopol i Konstantynopol, nie pierwszy raz przebywali także drogę do Kamieńca. W międzyczasie wysłannicy egzulantów jeździli też do Kamieńca, aby odzyskać pozostawione w mieście cenne przedmioty kościelne. O niektórych wysłannikach wiadomo, że zostali zabici po drodze. Ormianie, którzy pozostali w rodzinnym mieście, nie chcieli, względnie nie mogli, tych dóbr wydać. Nieruchomości opuszczone przez egzulantów w Kamieńcu zostały przejęte przez Turków. Wyjeżdżając z Filibe w 1677 roku, Ormianie domagali się od władz tureckich rekompensaty za zajęte nieruchomości z przeznaczeniem na koszty transportu (podwody). Chcieli też zgody na dołączenie do nich resztki Ormian z Kamieńca, którzy mogliby zabrać ze sobą dobra domowe i kościelne, można się domyślać, że przede wszystkim te zakopane.

Wykaz sporządzony przez Grzegorza Miłkiewicza cechuje skrupulatność i ład, co świadczy o wprawie w prowadzeniu skomplikowanych rachunków handlowych. Sprawozdawanie z przychodów i wydatków było jawne i odbywało się przed mniejszym lub większym gremium społecznym. Kościół i duchowni odgrywali ważną rolę w życiu wychodźców. Świadczą o tym starania o przyznanie świątyni w Filibe, łożenie na jej remont i naleganie, by kościół ten po wsze czasy został w ręku lokalnych Ormian.

Liczebność Ormian kamienieckich na wygnaniu w Sozopolu i Filibe jest trudna do ustalenia. Mowa było o ok. 200 osobach, które zmarły podczas zarazy. Około 150 osób otrzymało pożyczki i zapomogi w Filibe, ale byli to daleko nie wszyscy tam przebywający, a tylko najbardziej potrzebujący. Spis w „Lehahayer", 6 obejmował 425 osób. Pojawiły się jednak w nim imiona i nazwiska Ormian, którzy - jak wykazały to obecnie dostępne źródła - nie żyli już w 1672 roku, stanowiącym umowny początek spisu. Ludzie ci byli na ogół ofiarodawcami na rzecz wspólnoty wygnańców.

W spisie zamieszczonym poniżej, ułożonym alfabetycznie, znajdują się te osoby wymienione w „Lehahayer”, 6, co do których znalazły się nowe informacje i tylko te nowe informacje tu zamieszczam. Ich numer porządkowy jest taki, jak w „Lehahayer”, 6, czyli między 1 a 425. Odniesienia do miejsc geograficznych podaję w spisach tylko wtedy, gdy nie jest to Kamieniec Podolski. Gdy więc 
mowa jest o sądzie, kościele, wójcie (bez odwołania się do miejsca), to chodzi o kamieniecki sąd, kościół, wójta itp.

\section{Spis osób wymienionych w „Lehahayer”, 6, co do których pojawiły się nowe informacje, oraz osób zidentyfikowanych na podstawie nowych źródeł}

Syrma Torosowiczówna Abrahamowiczowa (Awramowiczowa) (1669-1748) (6) $^{\text {- córka }}$ Torosa Bogdanowicza (zob.) i Kirkorówny, żona Doniga Abrahamowicza (Awramowicza) Perduna (1659-1749), matka rajcy Abrahama Donigiewicza Perduna (17041767), pochowana w Stanisławowie.

Todoros [Abrawericz] - ksiądz, syn Abrawera (?) ${ }^{47}$, kawaler $(1681)^{48}$.

Sahak [Agopowicz] - syn Agopa (1681) ${ }^{49}$.

Aleksa (Waleksa) - syn księdza $(1681)^{50}$.

Baltazar Altunczyk († po 1699) - mąż Zofii, ojciec Anny Rypsymy, chrzczonej we Lwowie w 1699 roku, był chrzestnym w 1696 roku $^{51}$, prawdopodobnie tożsamy z Balcerem kuśnierzem, bratem Anny Altunki (zob.).

Anna Altunka († 21 sierpnia 1701 we Lwowie) - siostra kuśnierza Balcera (zob. Baltazar Altunczyk $)^{52}$. Możliwe, że tożsama z Altunkową, która w 1696 roku we Lwowie była matką chrzestną Jana, syna Jana złotnika ${ }^{53}$.

10. Awak Amirowicz - w sądzie pojawiał się dość często od $1646^{54}$ do 1660 roku $^{55}$. W 1676 roku w Filibe był przedstawicielem Rady Czterdziestu Mężów (Dokument nr 12). Miał dom przy ulicy Długiej, między domami ks. Krzysztofa Dzerigowicza a Doniga Łukaszowicza $(1652)^{56}$.

Danys [Andriaszowicz] - syn Andriasza (1681) ${ }^{57}$.

11. Andrusiowa (Jędrzejowa) - możliwe, że to ona przekazała „fartuszek” jako dar dla kościoła ormiańskiego w Stanisławowie ${ }^{58}$.

${ }^{46}$ FKiDOP: sygn. 9/36, Liber defunctorum parochianorum Stanislanoviensium Armenorum [1715-1829], s. 49.

${ }^{47}$ Znaki zapytania w przypadkach osób figurujących w źródle wydanym przez Dariusza Kołodziejczyka pochodzą od wydawcy.

${ }^{48}$ D. Kołodziejczyk, The Ottoman Survey, s. 89.

49 Ibidem, s. 88.

${ }^{50}$ Ibidem, s. 89.

${ }^{51}$ Metryka, s. 556, 568

${ }^{52}$ Metryka, s. 528: „R[oku] 1701 Sierpnia 21. Panu Bogu dusze oddała P[ani] Altunka na imię Anna z Kamieńca, siostra P[ana] Balcera Kuśnierza".

${ }^{53}$ Metryka, s. 556: „Ze świętego źródła podnieśli Pan Nerses Złotnik i Pani Altunkowa z Kamieńca”.

54 А. Н. Гаркавец, Кыпчакское письменное наследие, s. 934.

${ }^{55}$ ЦДІАУ: f. 39, op. 1, spr. 42, k. 160.

${ }^{56}$ Ibidem, spr. 158, k. $115 \mathrm{v}$.

57 D. Kołodziejczyk, The Ottoman Survey, s. 89.

${ }^{58}$ FKiDOP: sygn. 18/226, Inwentarz i księga wydatków K[ościoła] Pa[arafialnego] Ormiańskiego w Stanisławowie XVIII-XIX, s. 12. 
17. Zachariasz Arakiełowicz - brat Synana, który pojawiał się w sądzie od 1655 do 1660 roku ${ }^{59}$. W Filibe, w 1676 roku, jako przedstawiciel Rady Czterdziestu Mężów, był obecny przy rozliczaniu delegatów do Porty (Dokument nr 12).

Akyryt [Awedykowicz] - syn Awedyka $(1681)^{60}$.

188. Anna [Krzysztofowiczówna Kapaczykówna] Axentowa - siostra Jana Krzysztofowicza Kapaczyka (zob.), wdowa po Axencie (zob. „Lehahayer”, 6, s. 20).

31. Zarug (Dzarug, Caryk) Axentowicz - prawdopodobnie tożsamy z Maxymowiczem (zob. „Lehahayer”, 6, s. 49), teściem Stefana Serhiowicza Roszki (zob.) ${ }^{61}$. W sądzie stawał w różnym charakterze $(1654,1656,1661)$. W 1661 roku jako świadek zeznawał w sporze o dług między Asłanem Emirowiczem (zob.) a Danielem Mitkiewiczem (zob.), który toczył się w 1656 lub 1657 roku ,kiedy Witemberg [Arvid Wittenberg] był w Zamościu, ia, Agopsza y Daniel Mitkiewicz powracaiąc sie ze Gdanska przyiechalismy do Zamoscia"62.

Zofia [Axentowiczówna Czabliczówna] († 2 maja 1739 w Stanisławowie) - córka Axenta „Michałenc czabliczy” ${ }^{3}$ (Michałowicza Czabliczy); była zamężna.

33. Gabriel (Stefan) Babikowicz († 1675/1686 ${ }^{64}$ ) - w sądzie stawił się jako świadek w 1656 roku $^{65}$ i uwzględniony był jako obdarowany w spisie rzeczy (unh\$quphq diftarin) Marka Donawakowicza $(1661)^{66}$.

39. Bachczyńska - w 1676 roku w Filibe pieniądze za nią odebrał Jan Krzysztofowicz Kapaczyk (zob.). Prawdopodobnie żona któregoś z Bachczowiczów: Romasza (mieszkaniec Brodów zjawił się przed sądem w Kamieńcu w 1653 roku ${ }^{67}$ ), Jakuba (w sądzie w latach: $1655^{68}$ i $1663^{69}$ ) albo Serhija.

41. Krzysztof Bachdasarowicz (Bahdasarowicz, Baltazarowicz, Balcerowicz) Borszczowski, prawdopodobnie Hodowaniec (orm. łuuцpo 2nunnl: - Chaczko Hodow.) syn Baltazara Krzysztofowicza († przed 1656) ${ }^{70}$, brat Owanisa (zob.) (1655) ${ }^{71}$, mąż Anny Chodzikówny (zob.), ojciec ks. Aswadura Borszczowskiego (zob. „Lehahayer", 6, s. 28-29); w sądzie odnotowany w 1656 roku $^{72}$. W Sozopolu, w 1675 roku, był świadkiem spisania przedmiotów kościelnych (Dokument nr 3); jako przedstawiciel Rady Czterdziestu Mężów poświadczał inwentarz po śmierci wójta Kuryły Miłkiewicza (Dokument nr 3); przyjmował rozliczenie Murada Seferowicza (Dokument nr 4); był świadkiem powierzenia rzeczy kościelnych (Dokument nr 5); przyjmował rozliczenie delegatów powracających z Adrianopola i Janpola (Dokument nr 6). W Filibe

\footnotetext{
${ }^{59}$ ЦДІАУ: f. 39, op. 1, spr. 41, k. 119-119v.

${ }^{60}$ D. Kołodziejczyk, The Ottoman Survey, s. 88.

1 ЦДІАУ: f. 39, op. 1, spr. 41, k. 192v-193.

62 Ibidem, spr. 42, k. 189v.

3 FKiDOP: sygn. 9/36, Liber defunctorum, s. 37.

${ }^{4}$ BZNiO: sygn. 1732/II, Protocollum actorum consistorii, k. 55.

${ }^{5}$ ЦДІАУ: f. 39, op. 1, spr. 41, k. 220v.

66 Ibidem, k. 216.

${ }^{67}$ Ibidem, k. 38.

${ }^{68}$ Ibidem, k. 144v.

${ }^{69}$ Ibidem, spr. 42, k. 144v.

${ }^{70}$ Ibidem, spr. 158, k. 118.

71 Ibidem, spr. 41, k. 156.

72 Ibidem, spr. 42, k. 107.
} 
w 1675 roku jako oficjalista poświadczał wyprawę do Porty (Dokument nr 7); wydelegowany był do Porty z supliką do sułtana (Dokument nr 8).

42. $=45$. Owanis (Iwanis, Owanes) Bachdasarowicz [Borszczowski] - prawdopodobnie tożsamy z Iwanisem Borszczowskim i Janem Balcerowiczem (zob. „Lehahayer”, 6, s. 22) - brat Krzysztofa Bachdasarowicza (zob.) (1655) ${ }^{73}$; w Filibe notowany w 1676 roku jako Owanis Balcerowicz (Dokument nr 11) i jako przedstawiciel Rady Czterdziestu Mężów (Dokument nr 12).

43. Anna Chodzikówna (Chodzigiewiczówna) Bachdasarowiczowa Borszczowska żona Krzysztofa (zob.), matka ks. Aswadura (Bogdana) Borszczowskiego (zob. „Lehahayer", 6, s. 28-29).

Chaczadur (Krzysztof) [Bajramowicz] - syn Bajrama $(1681)^{74}$.

47. Szymon Balewicz - mąż Zofii (zob.), ojciec Baltazara Szymonowicza ${ }^{75}$ (zob.).

Zofia Balewiczowa - żona Szymona, matka Baltazara Szymonowicza ${ }^{76}$ (zob.). Błędnie podałam w „Lehahayer”, 6, że ta Zofia Balewiczowa była z Hanesowiczów 1v. Dryngarczykowa.

132. Zofia Hanesowiczówna 1v. Dryngaczykowa, 2v. Balewiczowa († po 1704) ${ }^{77}-$ jej pierwszym mężem był Krzysztof Dryngaczyk († przed 1682), drugim - Zachariasz (nie Szymon - zob. „Lehahayer”, 6, s. 35) Szehribal Balewicz (1682) ${ }^{78}$, pochodzący przypuszczalnie z Jazłowca mieszkaniec Stanisławowa, zmarły po $1704 \mathrm{roku}^{79}$. Na potrzeby zakładników lwowskich, przetrzymywanych od 1672 roku w Kamieńcu, pożyczyła 20 talarów lewkowych podobnie jak Elżbieta Jołczowiczowa (zob.). Zrzekła się tej sumy, odzyskanej przez Grzegorza Miłkiewicza (zob.), i w 1682 roku, mieszkając już w Stanisławowie, przeznaczyła ją na kościół ormiański stanisławowski i lwowski klasztor benedyktynek ormiańskich, by te modliły się za duszę jej zmarłego męża ${ }^{80}$. Prawo dysponowania nieruchomościami po pierwszym mężu w Stanisławowie przekazała w 1703 roku synowi, Bogdanowi Krzysztofowiczowi. Drugim jej mężem był Zachariasz Balewicz ${ }^{81}$. Zastanawia zbieżność jej danych z Marianną Balewiczową, której pierwszym mężem był Krzysztof Dryngacz († przed 1703), a drugim - Zachariasz Balewicz.

50. Stefan Balicki (Balewicz) $(\dagger 1692 \text { w Złoczowie) })^{82}$ - ksiądz, w 1675 roku w Sozopolu był obecny przy spisywaniu przedmiotów po śmierci wójta Kuryły i jako świadek powierzenia rzeczy kościelnych (Dokument nr 1, nr 3, nr 5).

73 Ibidem, spr. 41, k. 156.

74 D. Kołodziejczyk, The Ottoman Survey, s. 90.

75 Album civium Leopoliensium. Rejestry przyjęć do prawa miejskiego we Lwowie 13881783, 1, wyd. A. Janeczek, Poznań 2005, s. 343.

76 Ibidem, s. 343.

77 Львівська національна наукова бібліотека України імені В. Стефаника (dalej: ЛННБУ): sygn. f. 5, op. 1, spr. 1360/III Księga Akt Orm. No 3ti zaczęto 1703ciego Roku kaczy się 1709, s. 133.

${ }_{78}$ BZNiO: sygn. 1359/II, Akta sądu [...] w Stanisławowie 1681-1689, s. 161-163.

79 ЛННБУ: sygn. f. 5, op. 1, spr. 1360/III, s. 133.

${ }^{80}$ BZNiO: sygn. 1359/II, Akta sądu [...] w Stanisławowie 1681-1689, s. 162-163.

81 ЛННБУ: sygn. f. 5, op. 1, spr. 1360/III, s. 21.

${ }^{82}$ Archiwum Główne Akt Dawnych (dalej: AGAD): sygn. 456/1, Liber metricarum. Ecclesia Armena Zloczoviensis, s. 4. 
Jan [Janowicz] Kałusz (Kalust?) Baran (ur. 19 lutego 1690 we Lwowie) - syn Jana Barana (zob. „Lehahayer”, 6, s. 23).

52. Mikołaj Owanisowicz (Owaniszowicz, Owanisewicz) Baran („Bareni”) - prawdopodobnie tożsamy z Mikołajem Owankowiczem, który w 1676 roku w Filibe odebrał pieniądze: „moim y siostry moię imieniem” (Dokument nr 13).

[Owanisowiczówna Baranówna] - siostra Mikołaja (zob.).

Owsup (Owsep?) [Barsomowicz] - syna Barsoma (Parsama?) (1681) . $^{83}$

Gabriel Bartoszowicz - był świadkiem spisania przedmiotów kościelnych w Sozopolu w 1675 roku po śmierci wójta Kuryły Miłkiewicza (Dokument nr 3); powierzono mu część rzeczy kościelnych (Dokument nr 5); prawdopodobnie tenże Bartoszowicz występował w tym samym roku w Filibe (Dokument nr 7).

55. Katarzyna Bartoszowiczowa - córka Zofii i Miłka (Mikołaja) ${ }^{84}$, siostra (zob.): Axenta, Grzegorza i Kuryły Miłkiewiczów, wdowa $(1653)^{85}$. Możliwe, że ta sama była chrzestną w 1687 roku w Złoczowie. Być może tożsama z Bartoszowiczową (por. „Lehahayer”, 6, s. 23).

„Białey Popadiey corka” - w Filibe w 1676 roku otrzymała pieniądze (Dokument nr 13).

63. Jan (Iwanis) Bobrykiewicz († po 1676) - syn Bobryka Iwanisowicza ${ }^{86}$ (Owanesowicza, † po 1655, przysięgłego od 1635, prowizora kościołów kamienieckich, właściciela domu koło domu Tumana Serhiowicza), szwagier Augustyna Isajowicza ${ }^{87}$, brat przyrodni Krzysztofa Wartanowicza ${ }^{88}$ (zob.), niedoszły mąż Marty Pirumowiczówny (zob.) (1652) ${ }^{89}$, razem z nią chrzestny Hołuba Hołubowicza w Kamieńcu w 1664 roku ${ }^{90}$. Przedstawiciel Rady Czterdziestu Mężów $\left(1653,1654^{91}\right)$, cechmistrz kramarski (1656) ${ }^{92}$, miał dom przy Rynku Ormiańskim (1662) ${ }^{93}$. Jeden z czterech przysięgłych, którzy odpowiedzialni byli za spisanie przedmiotów kościelnych w Sozopolu w 1675 roku po śmierci wójta Kuryły Miłkiewicza (Dokument nr 1, nr 3, nr 5), wydelegowany do Porty (Dokument nr 2), wrócił z Adrianopola (Dokument nr 6), był w Filibe w 1676 roku (Dokument nr 16).

Bogdan - mąż Katarzyny Pierzadowiczówny Bogdanowej (zob.), w Sozopolu w 1675 roku był przy spisywaniu przedmiotów odbieranych po śmierci wójta Kuryły Miłkiewicza (Dokument nr 3).

Bogdanowa - córka Torosa Bogdanowicza (zob.) i Kirkorówny, żona Bogdana.

65. [Katarzyna?] Pierzadowiczówna [Bogdanowa] - córka Szymona Pierzadowicza (zob.), żona Bogdana (zob.), możliwe, że tożsama z Katarzyną Bogdanową (zob. „Lehahayer”, 6, s. 25), która otrzymała pieniądze w Filibe (Dokument nr 13).

83 D. Kołodziejczyk, The Ottoman Survey, s. 89.

${ }^{84}$ ЦДІАУ: f. 39, op. 1, spr. 158, k. 125-125v.

${ }^{85}$ Ibidem, spr. 41, k. 30-30v.

${ }^{86}$ Ibidem, spr. 158, k. $117 \mathrm{v}-118$.

${ }^{87}$ Ibidem, spr. 41, k. 153v.

${ }^{88}$ Ibidem, k. 17.

${ }^{89}$ Ibidem, spr. 158, k. 117v.

90 BZNiO: sygn. 1732/II, Protocollum actorum consistorii, k. 116.

91 ЦДІАУ: f. 39, op. 1, spr. 41, k. 113.

92 Ibidem, k. $205 \mathrm{v}$.

93 Ibidem, spr. 42, k. 244v. 
Owas (Jan) [Bogdanowicz] (Aswadurowicz) - syn Aswadura (1681) ${ }^{94}$.

Sarkis [Bogdanowicz] (Aswadurowicz) - syn Aswadura (1681) ${ }^{95}$.

67. Toros (Teodor) Bogdanowicz (ok. 1640-172796) - dwukrotnie żonaty; z Kirkorówną miał siedmioro dzieci, zwanych Torosowiczami (zob.): Jakuba, Bogdana, Zachariasza, Zaruga, Krzysztofa, Syrmę Abrahamowiczową; córkę nieznanego imienia, która wyszła za Bogdana. Około 1694 roku ożenił się w Stanisławowie z wdową Anną ${ }^{97}$. Wraz z bratem, Zachariaszem (zob. „Lehahayer”, 6, s. 25), był właścicielem gruntu przy Rynku Ormiańskim, między kamienicą Rospopowską a domem Harburasza. Zamieszkał w Stanisławowie około 1680 roku, kuśnierz w Stanisławowie (1700), wójt ${ }^{98}$.

57. Mikołaj Bogdanowicz Bekiesz (Bekieszczyk, Bekieszowicz) († 1 października 1689 we Lwowie ${ }^{99}$ ) - prawdopodobnie mąż Marencji (1653) ${ }^{100}$ i Zuzanny Talinówny (1677, zob. „Lehahayer”, nr 6, s. 24), safiannik (1648) ${ }^{101}$, młodszy cechmistrz cechu tabacharskiego - garbarzy $(1653)^{102}$, „towarzysz Chorągwie urodzonego Je[go] M[ości] Pana Franciszka Dziwanowskiego rothmistrza J[ego] K[rólewskiej] M[ości]" $(1660)^{103}$. W 1675 roku w Sozopolu był przedstawicielem Rady Czterdziestu Mężów (Dokument nr 3, nr 5, nr 6).

58. Szymon Bogdanowicz Bekiesz - mąż Rozalii (zob. „Lehahayer”, 6, s. 24); stawał w sądzie jako świadek w 1656 i 1662 roku $^{104}$. W 1676 roku był w Filibe (Dokument nr 11, nr 12).

Sarkis Bogdanowicz Roszka - syn Bogdana Stefanowicza Roszki i Edił z Kamieńca ${ }^{105}$. 399. Bogdan Bogdanowicz Torbacz († po 1699) - Bogdan Bogdanowicz i Bogdan Torbacz to prawdopodobnie ta sama osoba. Miał dwóch dorosłych synów (zob.), Stefana i Wartana ${ }^{106}$, kiedy żenił się w 1696 roku z Anną (zob.), córką Mikołaja Szymonowicza Karakasza (zob.) ${ }^{107}$. W 1659 i w 1660 roku stawał w sądzie kamienieckim ${ }^{108}$. W 1675 roku w Sozopolu był świadkiem spisania przedmiotów kościelnych (Dokument nr 3), jako jeden z Rady Czterdziestu Mężów przyjmował rozliczenie finansowe delegatów wracających z misji do Adrianopola i Janpola (Dokument nr 6), otrzymał pieniądze w Filibe (Dokument nr 13). W Stanisławowie: egzaktor (poborca podat-

\footnotetext{
${ }^{94}$ D. Kołodziejczyk, The Ottoman Survey, s. 88.

95 Ibidem, s. 89.

${ }^{96}$ FKiDOP: sygn. 9/36, Liber defunctorum, s. 24: „Dnia 25 listopada [1727]. Pan aga Toros z [rodu] Bogdana [zmarł], dawniej mieszkaniec Kamieńca, potem Stanisławowa, 87 lat”.

${ }^{97}$ FKiDOP: sygn. 9/39, Księga małżeństw 1700-1813, k. 5.

98 BZNiO: sygn. 1590/II, Akta sądu ormiańskiego w Stanisławowie z lat 1692-1702,
} s. 534,868 .

${ }^{99}$ Metryka, s. 525.

100 ЦДІАУ: f. 39, op. 1, spr. 41, k. 49v.

101 А. Н. Гаркавец, Кыпчакское письменное наследие, s. 938.

102 ЦДІАУ: f. 39, op. 1, spr. 41, k. 82v.

103 Ibidem, spr. 42, k. 134.

104 Ibidem, k. 221v.

105 Biblioteka Książąt Czartoryskich (Muzeum Narodowe) w Krakowie (dalej: B. Czart.): sygn. 3543 IV, Akta zaręczynowe, k. 53.

106 BZNiO: sygn. 1590/II, Akta sądu [...] w Stanisławowie z lat 1692-1702, s. 401.

107 B. Czart.: sygn. 3543 IV, k. 17.

108 ЦДІАУ: f. 39, op. 1, spr. 42, k. 120, 131. 
ków, 1682) $)^{109}$, ofiarował do kościoła ormiańskiego stanisławowskiego „duży krzyż srebrny pozłacany" (1682) ${ }^{110}$. Sąd stanisławowski miał dochodzić zwrotu jego długu kamienieckiego $(1685)^{111}$. Ponownie wzmiankowany w tym sądzie kilkukrotnie do 1699 roku $^{112}$.

Stefan Bogdanowicz Torbacz († po 1705) - syn Bogdana Bogdanowicza Torbacza (zob.), mąż Rozalii, córki Hanny i Jakuba Grzegorzewiczów (Kirkorowiczów) ${ }^{113}$. Występował jako świadek w sądzie konsystorskim $(1688)^{114}$, potem w różnych sprawach w sądzie stanisławowskim do 1705 roku $^{115}$.

Wartan Bogdanowicz Torbacz ${ }^{116}$ († po 1700) - syn Bogdana Bogdanowicza Torbacza (zob.), mąż Hanusi, córki Marianny Zielińskiej, mieszczki halickiej. W sądzie stanisławowskim wzmiankowany w latach 1695-1700

109. Ulchatunka Damenesztowa (Daminesztowa) [Bogdanowiczowa] († po 1695) żona Krzysztofa Dameneszta Bogdanowicza († po 1661, kupca), szwagierka Dawida († przed 1652); właścicielka kamienicy między Ratuszem Ormiańskim a kamienicą Tatuła Kirkorowicza, po teściu, Bogdanie Dameneszcie Hankowiczu ${ }^{118}$. W sporządzonym w Stanisławowie w 1696 roku testamencie prawie wszystkie swoje dobra, wraz ze wspomnianą kamienicą w Kamieńcu Podolskim, zapisała Zachariaszowi Romaszkiewiczowi (zob.), swemu chrześniakowi, który opiekował się nią od 1683 $\mathrm{roku}^{119}$.

Zofia Głowacka Bogdanowiczowa - córka Grzegorza Głowackiego (zob.), w 1687 roku we Lwowie wyszła za mąż za Gabriela Bogdanowicza z „Małej Armenii z miasta Kara Hisar [Şebinkarahisar]" 120.

Zofia Romaszkiewiczówna Bogdanowiczowa (1691-1732) - córka Zachariasza Romaszkiewicza (zob.), żona Todera Ediła Bogdanowicza, zmarła i pochowana w Stanisławowie ${ }^{121}$.

Mikołajowa Bogdanowiczowa Bekieszowa († 25 czerwca 1689 we Lwowie) - żona Mikołaja $^{122}$ (zob.).

Anna Mikołajewiczówna Karakaszówna Bogdanowiczowa Torbaczowa - córka Mikołaja Szymonowicza Karakasza (zob.) i Marianny, druga żona Bogdana Bogdanowicza Torbacza (zob.) (Stanisławów, 1696) ${ }^{123}$.

109 BZNiO: sygn. 1359/II, Akta sądu [...] w Stanisławowie 1681-1689, s. 22-23.

110 FKiDOP: sygn. 18/226, Inwentarz i księga wydatków, b. n. s.

111 BZNiO: sygn. 1732/II, Protocollum actorum consistorii, k. 24.

112 BZNiO: sygn. 1590/II, Akta sądu [...] w Stanisławowie z lat 1692-1702, s. 741.

113 Ibidem, s. 855.

114 BZNiO: sygn. 1732/II, Protocollum actorum consistorii, k. 97.

115 ЛННБУ: sygn. f. 5, op. 1, spr. 1360/III, s. 189.

116 BZNiO: sygn. 1590/II, Akta sądu [...] w Stanisławowie z lat 1692-1702, s. 407.

117 Ibidem, s. 883.

118 ЦДІАУ: f. 39, op. 1, spr. 158, k. 86.

119 BZNiO: sygn. 1359/II, Akta sądu [...] w Stanisławowie 1681-1689, s. 434-436.

${ }^{120}$ Metryka, s. 499.

121 FKiDOP: sygn. 9/36, Liber defunctorum parochianorum Stanislanoviensium Armenorum [1715-1829], s. 30.

${ }^{122}$ Metryka, s. 524.

123 B. Czart.: sygn. 3543 IV, k. 17. 
Aswadur (Bogdan) [Bohosowicz] - syn Bohosa (1681) ${ }^{124}$.

Hulecz (?) Bohos[owicz] - był w Szemaha (?) (1681) ${ }^{125}$.

72. Isaj Bohosowicz (Bohoszowicz) - mąż Zofii (zob. „Lehahayer”, 6, s. 26), ojciec Anny Rozalii (ochrzczona 20 kwietnia 1685) ${ }^{126}$; w 1703 roku przyjechał ze Złoczowa do Stanisławowa na rozprawę sądową przeciw Bogdanowi Krzysztofowiczowi Dryngaczowi (zob.) ${ }^{127}$.

73. Jakub Bohosowicz († przed 1695 ${ }^{128}$ ) - syn Horpyny, ojciec Jakubowiczów (zob.): Gabriela $^{129}$, Bohosa i Marianny Cyntwarowicz Mikołajewiczowej. Występował w ormiańskich księgach sądowych Kamieńca już w 1651 roku ${ }^{130}$. W 1652 roku wrócił z wyprawy kupieckiej do Konstantynopola ${ }^{131}$. Z Filibe wydelegowany trzykrotnie do Porty (Dokument nr 8, nr 14, nr 17) i jeszcze kilkukrotnie do Adrianopola (Dokument nr 11, nr 12, nr 19); jako przedstawiciel Rady Czterdziestu Mężów brał udział w spieniężaniu zastawów (Dokument nr 16).

Oremir (?) [Bohosowicz] - syn Bohosa (1681) $)^{132}$.

208. Piotr (Bedros) Bohosowicz (Pawłowicz) Koczak (Koczakowicz) - Bedros Koczakowicz i Bedros Koczak Pawłowicz to prawdopodobnie ta sama osoba. Jako Pawłowicz notowany w sądzie w 1661 roku $^{133}$, jako Koczakowicz - w 1676 roku w Filibe, przedstawiciel Rady Czterdziestu Mężów (Dokument nr 11, nr 12, nr 13, nr 16).

76. Anna Bohosowiczowa - $(\dagger \text { po } 1700)^{134}$.

Anna Rozalia Bohosowiczówna - córka Isaja Bohosowicza (zob.) i Zofii (zob. „Lehahayer”, 6, s. 26), która ochrzczona została w Złoczowie 20 kwietnia 1685 roku $^{135}$.

Browar - zob. Zachariaszewicz.

80. Zadik (Zachariasz) Browar - usunięty z listy, gdyż zmarł przed 1668 rokiem $^{136}$.

81. [Browarczykowa] - zob. pełną notę jako Zachariaszewiczowa Róża.

82. Ewa [Browarówna] - usunięta z listy, gdyż Mirosława Zakrzewska-Dubasowa omyłkowo imię to przypisała Helenie, córce Serhija Zachariaszewicza Browara (zob.).

83. Brunon - usunięty z listy, gdyż chodzi tu o Serhija Zachariaszewicza Browara (zob.).

85. Bogdan Butachowicz ( $\dagger$ przed 1677) - z pierwszej żony - Zofii $(\dagger 1653)^{137}$, córki Iwanisa Kurkulisa († ok. 1653) i Anny Kurkuliski (zob.) - miał dzieci ${ }^{138}$. Występował

\footnotetext{
${ }^{24}$ D. Kołodziejczyk, The Ottoman Survey, s. 88.

25 Ibidem.

126 AGAD: sygn. 456/1, Liber metricarum, k. 1a, 14.

127 ЛННБУ: sygn. f. 5, op. 1, spr. 1360/III, s. 11.

128 BZNiO: sygn. 1590/II, Akta sądu [...] w Stanisławowie z lat 1692-1702, s. 287.

129 BZNiO: sygn. 1732/II, Protocollum actorum consistorii, k. 96.

130 ЦДІАУ: f. 39, op. 1, spr. 41, k. 18.

131 Ibidem, k. 140v.

132 D. Kołodziejczyk, The Ottoman Survey, s. 89.

133 ЦДІАУ: f. 39, op. 1, spr. 42, k. 195.

134 BZNiO: sygn. 1590/II, Akta sądu [...] w Stanisławowie z lat 1692-1702, s. 877.

135 AGAD: sygn. 456/1, Liber metricarum, k. 1a, 14.

136 Национальный исторический архив Беларуси в г. Минске (dalej: НИАБ): ф. 1807, оп. 1, од. 1, Akta sądu ormiańskiego w Zamościu 1660-1668, k. 256v-257v.

137 ЦДІАУ: f. 39, op. 1, spr. 158, k. 200v.

138 Ibidem, k. 200v-201.
} 
w sprawach sądowych $\left(1635^{139}\right)$, także jako przedstawiciel Rady Czterdziestu Mężów $\left(1652^{140}, 1653^{141}\right)$ i jako przysięgły $\left(1660^{142}\right)$.

88. Rozalia Butachowiczowa, mylnie w „Lehahayer”, 6 nazwana żoną Grzegorza, powinno być: Bogdana.

Wartan Cartu[mel?] (chrzczony 30 kwietnia 1687 we Lwowie) - syn Szymona Cartu[mela?] ${ }^{143}$ (zob. „Lehahayer”, 6, s. 31).

Anna Cartumelówna [Kartumelówna] - możliwe, że córka Szymona Cartu[mela?] (zob. „Lehahayer”, 6, s. 31), wdowa, w 1699 roku we Lwowie wyszła za Tomasza Bogdana Lomankę ${ }^{144}$.

98. Mikołaj (Nigoł) Chrzanowski (Chrzanowicz) († przed $1690^{145}$ ) - w 1676 roku w Filibe był obecny przy rozliczaniu delegacji do Adrianopola (Dokument nr 11).

100. Iwanis Chutlubejowicz - starszy cechmistrz cechu tabacharskiego (1653) ${ }^{146}$, w sądzie, jako świadek, odnotowany w 1661 roku; potem mieszkaniec Brzeżan $(1688)^{147}$.

Seweryn Cyran Łucznik († 2 marca 1695 we Lwowie) $)^{148}$ - por. Katarzyna Cyranówna Demozka.

Zuzanna Milkonowa Czajkowska († 22 lutego 1704 we Lwowie) - żona Milkona, złotnika $^{149}$ (zob.), prawdopodobnie tożsama z Czaykowską (zob. „Lehahayer”, 6, s. 32).

Helena Milkonówna Czajkowska (ur. 4 listopada 1700 we Lwowie) ${ }^{150}$ - córka Milkona Czajowskiego (zob.).

Marianna Milkonówna Czajkowska (ur. 6 maja 1696 we Lwowie) ${ }^{151}$ - córka Milkona Czajowskiego (zob.).

Rozalia Milkonówna Czajkowska (ur. 11 marca 1699 we Lwowie) $)^{152}$ - córka Milkona Czajowskiego (zob.).

290. Milkon (Melkon, Melkor) Czajkowski - prawdopodobnie tożsamy ze złotnikiem, mężem Zuzanny (zob.); jego córka Marianna była chrzczona we Lwowie w 1696 $\mathrm{roku}^{153}$.

Zachariasz Czaykowski - w 1713 roku ożenił się w Złoczowie z Marianną Wartykowiczówną ${ }^{154}$.

106. Róża Czornuszówna (Dokument nr 13).

139 А. Н. Гаркавец, Кыпчакское письменное наследие, s. 929.

${ }^{140}$ ЦДІАУ: f. 39, op. 1, spr. 158, k. 185.

141 Ibidem, spr. 41, k. 53v.

${ }^{142}$ Ibidem, spr. 42, k. 142v.

${ }_{143}$ Metryka, s. 497.

144 Ibidem, s. 510.

145 BZNiO: sygn. 1732/II, Protocollon spraw, k. 178v.

146 ЦДІАУ: f. 39, op. 1, spr. 41, k. 82v.

147 BZNiO: sygn. 1732/II, Protocollon spraw, k. 108.

148 Metryka, s. 526: „Panu Bogu oddał duszę P[an] Seweryn Cyran Łucznik [?]”.

149 Ibidem, s. 530.

150 Ibidem, s. 574.

151 Ibidem, s. 555.

152 Ibidem, s. 566.

153 Ibidem, s. 513, 530, 555.

154 AGAD: sygn. 456/1, Liber metricarum, s. 55. 
111. Katarzyna Cyranówna Demozka (raczej tak niż Denioska, jak podałam w „Lehahayer”, 6) († 24 czerwca 1703 we Lwowie) ${ }^{155}$ - por. Seweryn Cyran Łucznik.

Kasper [Danielowicz, Mitkiewicz] - syn Daniela i Zofii Mitkiewiczów (zob.).

Axent Dawidowicz (Tawitowicz) - w 1676 roku w Filibe był przy rozliczaniu delegacji do Adrianopola (Dokument nr 11).

Ohan (?) [Dawidowicz] - syn Dawida z Tyflisu, był u Porty (1681) $)^{156}$.

40. Muchałka Bachczyna Popowiczowa Deraswadurowiczowa - prawdopodobnie tożsama z Bachczyńską „starą” (por. „Lehahayer”, nr 6, s. 21) - jako „Bachczyna” odebrała pieniądze w 1676 roku w Filibe (Dokument nr 13). Druga żona Bachczy Popowicza Deraswadurowicza (zmarłego 1651/1652 podczas zarazy). Muchałka miała z Bachczą córkę Mariamkę i dwóch synów Bachczowiczów: Jakuba i Serhija, inni dwaj synowie zmarli podczas zarazy. Porzuciła Bachczę, a on oddalił ją na cztery lata przed swoją śmiercią; pochodziła z Wołoszczyzny i tam, co miała, „poprzedała i rozflarzyła”, prowadziła walkę w sądzie o spadek po Bachczy z jego dziećmi z pierwszego małżeństwa ${ }^{157}$. Pojawiała się w licznych sprawach sądowych jeszcze w 1663 roku $^{158}$.

112. Carko (Zarug) Derchaczadurowicz - właściciel domu Cyranowskiego między placem Serhija Kiejanina a domem Rapackiego $(1656)^{159}$.

113. $=$ 93. Urszula [Derchaczadurowiczowa] - prawdopodobnie tożsama z Carkową („Lehahayer”, 6, s. 31), w jej imieniu pieniądze w Filibe w 1676 roku odebrał Iwaszko Serhiowicz Rusinowicz (zob.) (Dokument nr 13).

118. Jakub Derkirkorowicz - był świadkiem w sprawie przed sądem ormiańskim w Kamieńcu w 1656 roku $^{160}$. W 1676 roku w Filibe uczestniczył w rozliczeniu wyprawy do Adrianopola (Dokument nr 11).

119. Michał Dermichałowicz (Der Michałowicz) († 12 stycznia 1683 we Lwowie $^{161}$ ) ksiądz, w sądzie jako Jakub (przed święceniami) ${ }^{162}$, brat: Anastazji Zachariaszewiczowej (zob.) ${ }^{163}$ i zakonnicy Mandzi († ok. 1659 w Jerozolimie ${ }^{164}$ ). Teść Grzegorza Głowackiego (zob.). Przed sądem w 1652 roku występował jako „kompromisariusz” w sprawie spadku po Sahagu Kirkorowiczu ${ }^{165}$, w 1675 roku w Sozopolu był przy przejmowaniu przedmiotów po śmierci wójta Kuryły Miłkiewicza (Dokument nr 1, nr 3), był świadkiem powierzenia rzeczy kościelnych (Dokument nr 5), rozliczania delegacji do Adrianopola (Dokument nr 6), w 1676 roku - w Filibe (Dokument nr 7, $\mathrm{nr} 11, \mathrm{nr} 12$, nr 15, nr 16, nr 18); wydelegowany do Porty, by spieniężyć przedmioty kościelne na remont kościoła (Dokument nr 10).

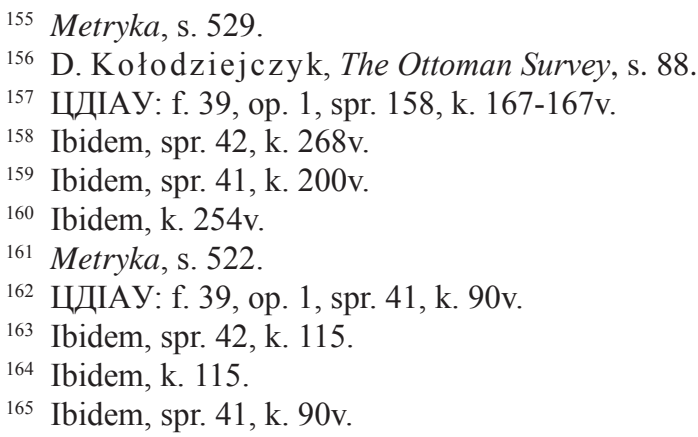


395. Dertorosowa [Teodorowa] - w 1676 roku w Filibe otrzymała pieniądze (Dokument nr 13).

127. Abraham (Abram) Donigowicz (Donikiewicz) - w 1704 roku wpłacił 100 talarów na okup nałożony na Lwów przez Szwedów ${ }^{166}$.

126. Theodor (Toros) Donigowicz (Donikowicz) - w Filibe w 1676 roku był obecny przy rozliczaniu delegatów do Adrianopola (Dokument nr 11) i odebrał pieniądze za swoją matkę i prawdopodobnie córkę Bogdana Babowicza (por. Bogdana Babowicza córki, „Lehehayer”, 6, s. 21): „,imieniem Matki moię podpisuię się [...] imieniem Aswadurownej podpis[uję się]" (Dokument nr 13). Możliwe, że tożsamy z Torosem / Theodorem Donigowiczem z Tyśmienicy, który stawał przed sądem stanisławowskim w latach 1692-1693, m.in. w sprawie przeciw Jakubowi Bohosowiczowi (zob.) $)^{167}$.

129. Stefan (Stepan) Dryngacz (Dryngaczyk) († przed 1687) ${ }^{168}$ - mąż Rozalii (zob.), możliwe, że szwagier Krzyśka Kieresza (zob.), a w takim razie zmarłby przed 1676 rokiem. Około 1663 roku, jako posłaniec Chodzika Hołubowicza, wiózł list hetmana wielkiego koronnego, Stanisława Rewery Potockiego, do hospodara wołoskiego, by hetmanowi ,wolno było bez wszelakich trudnosci i płacenia ceł woły posprawowac i do Polski prowadzic"169. Niesłusznie zatrzymany przez mytników mołdawskich, został uwięziony, a następnie wykupiony wraz z synem przez Hołubowicza za 120 talarów lewkowych ${ }^{170}$.

Dryngaczowa - w 1676 roku w Filibe dała swoje złoto do zastawienia (Dokument nr 11).

130. Rozalia Dryngaczykowa (Dryngacz) - możliwe, że siostra Krzyśka Kieresza (zob.), który wziął dla niej pieniądze w Filibe w 1676 roku, żona Stefana Dryngacza (zob.): „y tez imieniem siostry moię Stephanowy wdowy podpis[uję się]” (Dokument nr 13).

133. Horpyna (Garpina) Piotrówna Dydranowa - otrzymała pieniądze w Filibe w 1676 roku (Dokument nr 13).

135. Krzysztof Dziudziu (Dziurdzo) - możliwe, że tożsamy z Chaczykiem Agopszowiczem z Dziurdżiowa (Gyergyószentmiklós), który w latach 1683 i 1695 pojawiał się w sądzie ormiańskim w Stanisławowie ${ }^{171}$.

136. Mikołaj (Nigol) Embejowicz - w 1676 roku w Filibe obecny przy rozliczaniu delegacji do Adrianopola (Dokument nr 11).

137. Asłan Zachariasz Emirowicz (Amirowicz) († przed 1689) - wójt w Brodach, mąż Zofii (zob.), ojciec: Marii Miłkiewiczowej (zob.), mniszki Anny i prawdopodobnie Zachariasza Asłana Emirowicza (zob.). W Kamieńcu, w latach od $1651^{172}$ do $1661^{173}$,

166 J. Kopczyńs ki, Struktura i finanse gminy ormiańskiej we Lwowie w świetle rękopisu „Dzieje Ormian lwowskich od r. 1649 aż do r. 1713”, „Lehahayer”, 4, 2017, s. 66.

167 BZNiO: sygn. 1590/II, Akta sądu [...] w Stanisławowie z lat 1692-1702, s. 92.

168 BZNiO: sygn. 1732/II, Protocollon spraw, k. 90v.

169 ЦДІАУ: f. 39, op. 1, spr. 42, k. 258.

170 Ibidem, k. 258.

171 BZNiO: sygn. 1359/II, Akta sądu [...] w Stanisławowie 1681-1689, s. 201; sygn. 1590/II, Akta sądu [...] w Stanisławowie z lat 1692-1702, s. 325.

172 ЦДІАУ: f. 39, op. 1, spr. 158, k. 59-59v.

173 Ibidem, spr. 42, k. 189v. 
brał udział w wielu sprawach sądowych, głównie dotyczących rozliczeń finansowych w rodzinie żony, zwłaszcza litygował się ze szwagrem, Krzysztofem Pirumowiczem (zob.). Toczył spór sądowy z Danielem Mitkiewiczem (zob.) o sprawę z Zamościa z 1656 lub 1657 roku $^{174}$. Prawdopodobnie on był ofiarodawcą zielonego ornatu „z rytego aksamitu”, który mieli ze sobą wygnańcy kamienieccy w Sozopolu w 1675 roku (Dokument nr 3). Pieniądze zakładnikom lwowskim w Kamieńcu dał nie on, jak podałam w „Lehahayer”, 6, a jego syn, Zachariasz.

Mardyros [Emirhanowicz, Emirowicz?] - syn Emirhana (1681) ${ }^{175}$.

22. Zachariasz Asłan Emirowicz ( $†$ 1675/1682) - prawdopodobnie syn Asłana i Zofii Emirowiczów (zob.). To on dla zakładników lwowskich pozostających w Kamieńcu pożyczył niedługo po 11 listopada 1673 roku 200 talarów lewkowych od Zuzanny z Awedykowiczów Pirumowiczowej (zob.). Weksle (membrany) wziął ze sobą, gdy Ormianie zostali wygnani przez Turków z Kamieńca ,y prętko potym w Wołoszech zabity iest"176. W 1675 roku z Sozopola wydelegowany był do Porty (Dokument nr 2); tam też występował jako przedstawiciel Rady Czterdziestu Mężów (Dokument nr 3, nr 5, nr 6); także obecny w Filibe (Dokument nr 7). Możliwe, że tożsamy z Zachariaszem Asłanowiczem, pierwszym mężem Elżbiety Jołowiczowej ${ }^{177}$.

138. Zofia Pirumowiczówna Emirowiczowa († po 1689) - córka Jakuba Pirumowicza i Anny Kasprówny, siostra: biskupa Grzegorza, Krzysztofa (zob.), Katarzyny Krzysztofowiczowej (żony Iwaszka Beznosego) ${ }^{178}$, Mikołaja ${ }^{179}$ (zob. Zuzanna Pirumowiczowa), Gertrudy ${ }^{180}$ (zob.), Marty (zob.), Zuzanny Nurinowiczowej ${ }^{181}$; prawdopodobnie matka Zachariasza Asłana Emirowicza (zob.). Występowała w sprawach sądowych toczących się w rodzinie Pirumowiczów $\left(1651^{182}-1653^{183}\right)$.

Furanecz (?) Askerhas (?) - był w Kilis (1681) ${ }^{184}$.

Bogas (Bohos?) [Giragosowicz] - syn Kirakosa $(1681)^{185}$.

Chaczeres (Krzysztof) [Giragosowicz] - syn Kirakosa $(1681)^{186}$.

Nikogos (Mikołaj) [Giragosowicz] - syn Kirakosa [Krzysztofowicza] (zob.), wnuk Chaczadura $(1681)^{187}$.

Halka Głowacka (ur. 28 października 1677 we Lwowie) - córka Grzegorza Głowackie$\mathrm{go}^{188}$ (zob.).

174 Ibidem, k. 189v.

175 D. Kołodziejczyk, The Ottoman Survey, s. 89.

176 Центральний державний історичний архів України, м. Львів (dalej: ЦДІАУЛ):

f. 52, op. 2, spr. 531, Acta iudicii civilis Armenorum, s. 1540, 1569.

177 BZNiO: sygn. 1359/II, Akta sądu [...] w Stanisławowie 1681-1689, s. 161-163.

178 ЦДІАУ: f. 39, op. 1, spr. 158, k. 98.

179 Ibidem, k. 107.

${ }^{180}$ Ibidem, k. 90.

181 Ibidem, k. 188v.

182 Ibidem, k. 61-61v.

183 Ibidem, spr. 41, k. 8v-9.

184 D. Kołodziejczyk, The Ottoman Survey, s. 88.

185 Ibidem, s. 89.

186 Ibidem, s. 88.

187 Ibidem, s. 89.

188 Metryka, s. 473. 
143. Grzegorz (Kirkor) Krzysztofowicz Glowacki († 13 września 1704 ${ }^{189}$ ) - prawdopodobnie syn Krzysztofa Jakubowicza Głowackiego i Zofii, córki Łukasza, brat: Jana, Axenta (1652) ${ }^{190}$, młodszy brat Jakuba (1652) ${ }^{191}$, ojciec Halki Głowackiej (zob.), zięć księdza Michała Dermichałowicza (zob.). W sądzie stawiał się w różnym charakterze na przestrzeni lat 1651-1661 ${ }^{192}$. Aktywny na wygnaniu także jako przedstawiciel Rady Czterdziestu Mężów w 1675 roku w Sozopolu (Dokument nr 3, nr 5, nr 6) oraz w 1675 i 1676 roku w Filibe (Dokument nr 7, nr 12, nr 15).

Jan Krzysztofowicz Głowacki - brat Grzegorza (zob.), miał żonę (zob. Głowacka - „Lehahayer", 6, s. 36).

144. Grzegorz Jakub Gogczewicz (Gokczewicz, Goxowicz) - prawdopodobnie syn Gogczy Derabrahamowicza ( $\dagger$ przed 1651), brat: Aswadura ( $\dagger$ po 1656) ${ }^{193}$; Czaryka († po 1661, ojca „wstydliwej” Marencji ${ }^{194}$ ); Zofii (od 1613 roku żony Jakuba Iwaszkowicza ze Lwowa); Piotra († przed 1651, ożenionego z Elżbietą, właściciela kamienicy Goxowskiej między kamienicą Kirkorszy Hołubowicza a domem Axenta Iwanisowicza); brat: Iwaszki, ojca Gogczewiczówny (zob.); Krzysztofa, właściciela kamienicy przy Rynku Ormiańskim (1658) ${ }^{195}$, przysięgłego do 1659 roku ${ }^{196}$.

146. Owakowiczówna (Awakowiczówna) Grzybowska († przed 1704) - wnuczka Caryka Beznosego Krzysztofowicza († ok. 1654 ${ }^{197}$ ), córka Anny Carykówny $\left(\dagger 1651 / 1652^{198}\right)$ i Owaka Kirkorowicza $\left(\dagger 1654^{199}\right.$, który miał dom przy Rynku Ormiańskim ${ }^{200}$ ), siostra: Krzysztofa Owakowicza, który ożenił się z Ormianką(?) ze Lwowa w 1645 roku $^{201}$, Heleny 1v. Krzysztofowiczowej, 2v. Seferowiczowej (zob.), Róży Krzysztofowiczowej (zob.).

Gulka (Guliczka) staruszka - chrzestna we Lwowie w latach: 1696, 1697, $1698^{202}$.

Hanes - zięć Bekiesza, był świadkiem spisania przedmiotów kościelnych w 1675 roku w Sozopolu (Dokument nr 3).

148. Mikołaj Hanesowicz - safiannik, teść Szymona (Szymy) Krzysztofowicza $(1655)^{203}$. W sprawie sądowej obecny już w 1641 roku $^{204}$. W zapisach z Sozopola występuje trzy razy, w tym raz jako przedstawiciel Rady Czterdziestu Mężów (Dokument nr 1, nr 3, nr 5).

189 Ibidem, s. 530: „Panu Bogu oddał duszę P[an] Grzegorz Głowacki Września 13 [o] godzinie 13 na wielkim zegarze".

${ }^{190}$ ЦДІАУ: f. 39, op. 1, spr. 158, k. 9-9v.

191 Ibidem, k. 142-142v.

192 Ibidem, spr. 42, k. 188.

193 Ibidem, spr. 41, k. 198v-199.

194 Ibidem, spr. 42, k. 187.

195 Ibidem, spr. 41, k. 88v.

196 Ibidem, spr. 42, k. 90v.

197 Ibidem, spr. 41, k. 86.

198 Ibidem, spr. 158, k. 85v.

199 Ibidem, spr. 41, k. 62v.

200 Ibidem, k. 165.

${ }^{201}$ Ibidem, spr. 42, k. 104v.

${ }^{202}$ Metryka, s. 556, 559, 563.

203 ЦДІАУ: f. 39, op. 1, spr. 41, k. 135.

204 А. Н. Гаркавец, Кыпчакское письменное наследие, s. 931. 
Aksent [Hawdasarowicz] - syn Hawdasara (?), brat Torosa (zob.) (1681) ${ }^{205}$.

Aswadur [Hawdasarowicz] - syn Hawdasara (?), brat (zob.): Ibrahima i Pawło (1681) ${ }^{206}$. Ibrahim [Hawdasarowicz] - syn Hawdasara (?), brat (zob.): Aswadura i Pawło, był w Edirne $(1681)^{207}$.

Pawło [Hawdasarowicz] - syn Hawdasara (?), brat (zob.): Aswadura i Ibrahima $(1681)^{208}$.

Toros [Hawdasarowicz] - syn Hawdasara (?), brat Aksenta (zob.) (1681) ${ }^{209}$.

Róża Hodowańcówna - w jej imieniu w Filibe w 1676 roku pieniądze wziął Owanko (Owak) Stefanowicz (zob.): „imieniem Popadię y Rozy Hodowancowney (Dokument nr 13).

152. Chodzik Hołubowicz $(†$ 1676/1686) - syn Hołuba Kirkorowicza (wójta od 1577 roku $^{210}$, także w 1595 roku $^{211}$, dobrodzieja Kamieńca; jego przodkowie ufundowali kościół Wniebowzięcia Najświętszej Panny, a on sam łożył na jego ozdobienie); brat: ks. Nersesa (zob.), Kirkorszy († 1651) - wójta i erespochana, Zofii Romaszowej († ok. 1660); mąż Róży Miłkówny ${ }^{212}$; ojciec: Jana Chodzikiewicza Hołubowicza (zob. „Lehahayer”, 6, s. 38), Justyny Axentowiczowej (tamże, s. 38) 213, Anny Bachdasarowiczowej Borszczowskiej (tamże, s. 22) i Marencji Pirumowiczowej (zob.). W 1651 roku był przysięgłym, czyli ławnikiem, w sądzie ${ }^{214}$ i wiadomo, że pełnił tę funkcję (możliwe, że z przerwą w roku 1659) do 1666 roku $^{215}$. Miał kamienicę przy Rynku Ormiańskim, między kamienicą Mowsesowską a domem Jakuba Lewonowicza ${ }^{216}$. W 1656 roku występował jako poszkodowany przed sądem gajonym kryminalnym ormiańskim ${ }^{217}$. Jako jeden z plenipotentów Kazimierza Aleksandra Brodowskiego, sekretarza królewskiego, zapisany jest w księdze sądu po polsku jako Chodzik, a po łacinie jako „Luca”, Łukasz $^{218}$ i ponownie, w 1662 roku, określany jest jako Łukasz Chodzik i jako Luca ${ }^{219}$. Na wygnaniu w Sozopolu występował jako ,przysięgły” i „oficjalista” (Dokument nr 1, nr 3, nr 5, nr 6), w Filibe - jako „oficjalista” (Dokument nr 7, nr 12, nr 16).

${ }^{205}$ D. Kołodziejczyk, The Ottoman Survey, s. 89.

206 Ibidem, s. 88.

207 Ibidem.

208 Ibidem.

209 Ibidem.

210 А. Н. Гаркавец, Кыпчакское письменное наследие, s. 874.

${ }^{211}$ K. S topka, „Jako ojczyc prawdziwy ojczyzne swa miła chcac tym lepiej przyozdobic””. Historia dział Michnowskich niegdyś Kamieniec Podolski broniących, w: Amicissima. Studia Magdalenae Piwocka oblata, Cracoviae 2010, s. 245.

${ }^{212}$ ЦДІАУ: f. 39, op. 1, spr. 158, k. 101.

${ }^{213}$ BZNiO: sygn. 1732/II, Protocollum actorum consistorii, k. 165v-166.

${ }^{214}$ ЦДІАУ: f. 39, op. 1, spr. 158, k. 5v.

215 Ibidem, spr. 42, k. 234; S. Krzyżanow ski, Pamiątki polskie w Muzeum Towarzystwa Historyi i Archeologii w Odessie, Kijów 1863, s. 41-42.

${ }^{216}$ ЦДІАУ: f. 39, op. 1, spr. 41, k. 77.

217 Ibidem, k. 254.

${ }^{218}$ Ibidem, k. 219v.

219 Ibidem, spr. 42, k. 230v, 236v. 
Kirkor Dernerses[owicz] Hołubowicz - syn ks. Nersesa Hołubowicza, kleryk $(1658)^{220}$, później ksiądz (1659) we Lwowie 221 .

Łukasz Krzysztof[owicz] Hołubowicz († 1675/1686) - możliwe, że syn Krzysztofa Hołubowicza († przed 1658)222, mąż Róży Awakowiczówny (zob.), wójt, wraz z żoną został w Kamieńcu ${ }^{223}$, nie ma go w tureckim defterze z 1681 roku.

156. Nerses Hołubowicz (1582 - po 1670) - ksiądz, syn Hołuba Kirkorowicza, zięć ks. Zachariasza ${ }^{224}$, szwagier Murada Zachariaszewicza (zob.), ojciec: ks. Tomasza Nersesa Hołubowicza ${ }^{225}$, ks. Kirkora Hołubowicza ${ }^{226}$ (zob.), ks. Simona Hołubowicza $^{227}$ (zob.), Marty Dersymonowej Mikołajewiczowej228 (,„popadii”, żony ks. Szymona $^{229}$, która w sprawach sądowych pojawiła się najpóźniej w 1656 roku $^{230}$ ). Spowiednik Gertrudy Serhiowiczowej $(1651)^{231}$, zakrystian kościoła Wniebowzięcia Najświętszej Panny (1653) ${ }^{232}$, „officiał duchowienstwa ormianskiego kamienieckiego" $\left(1658^{233}, 1659^{234}, 1661^{235}\right)$. Mieszkał w domu ojcowskim, który stał w obszarze jurysdykcji ruskiej, na przeciwko kościoła św. Mikołaja, i zwolniony został przez króla z wszelkich podatków miejskich - prywatnych i publicznych oraz kwaterunku $(1661)^{236}$.

153. Nerses Tomasz[owicz] Hołubowicz (1664-1704) - syn ks. Tomasza Nersesa Hołubowicza ${ }^{237}$ (zob.) i Heleny Serhiówny (zob. „Lehahayer”, 6, s. 39), na chrzcie otrzymał imię Hołub, po święceniach - Nerses ${ }^{238}$, wnuk ks. Nersesa Hołubowicza (zob.). Zapewne przyjęty do Papieskiego Kolegium we Lwowie, służył w kapitule lwowskiej w 1686 roku jako sługa (servitor) ${ }^{239}$, w 1688 roku był po pierwszej tonsurze $^{240}$. Ksiądz w Stanisławowie, gdzie pojawiał się przed sądem: jako spowiednik Ulchatunki [Bogdanowiczowej] Damenesztowej ${ }^{241}$ (zob.), dalej-głównie z powodu

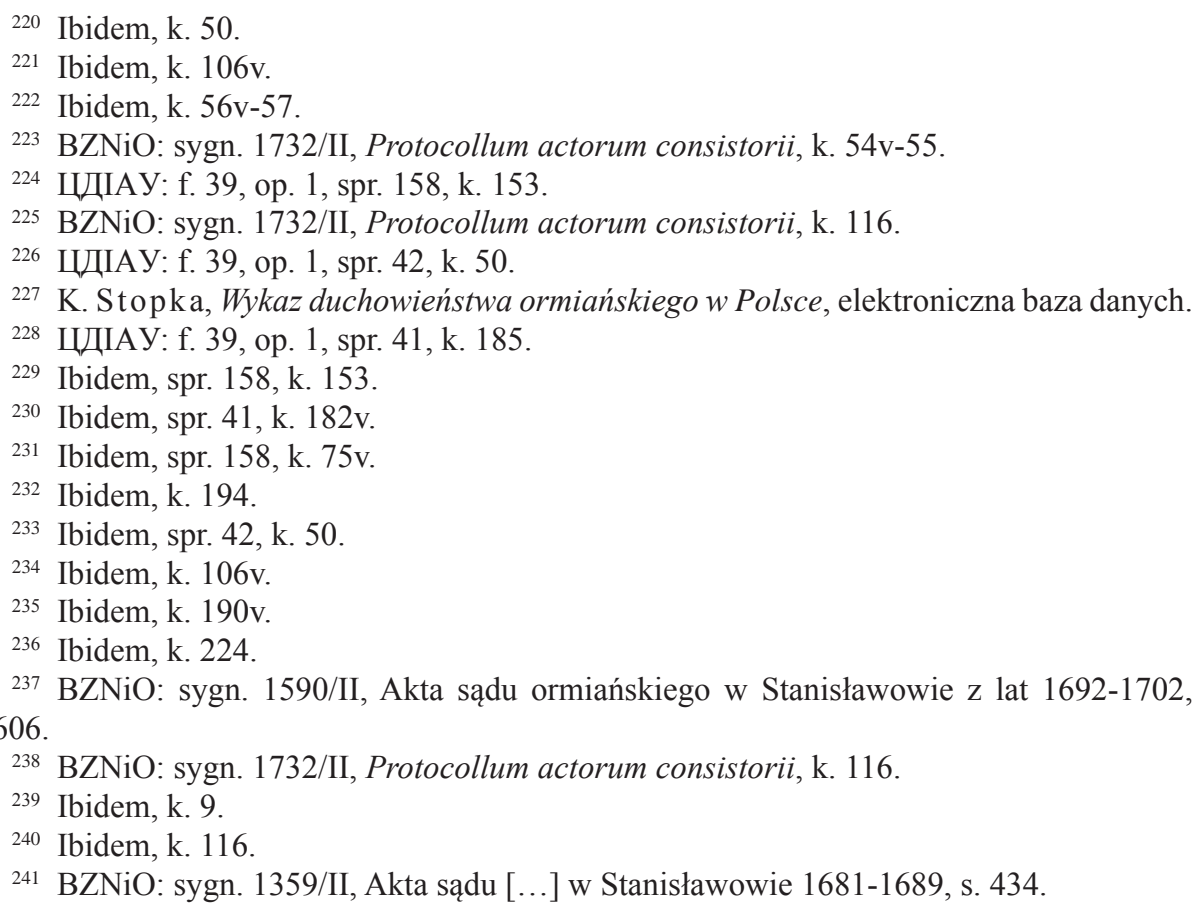


bójek z kotlarzem Iwanem²42 i w latach 1695-1698 przy spisywaniu krorąków ${ }^{243}$. W 1698 roku przeniósł się do innego miasta ${ }^{244}$, we Lwowie był wikarym (1701, $1703,1704)^{245}$, pojawił się w Stanisławowie jeszcze w 1704 roku $^{246}$.

Simon Hołubowicz - syn ks. Neresa Hołubowicza, ksiądz, ojciec Krzysztofa ${ }^{247}$.

157. Tomasz Nerses[owicz] Hołubowicz († przed 1688) - syn ks. Nersesa Hołubowicza (zob.), ojciec ks. Nersesa Tomasza Hołubowicza (zob.).

159. Róża Awakowiczówna Hołubowiczowa († po 1686) 248 - błędnie podałam w „Lehahayer", 6, że była siostrą Grzybowskiej i że zmarła we Lwowie 3 lipca 1704 roku.

207. Usunięta z listy: Saruchna [Sara] Balcerowiczówna [Baltazarówna, Bachdasarówna] Kirkorszowa [Kirkorszyna] Hołubowiczowa († 1657/1659).

162. Bernat Isajowicz (Isajewicz) (ok. 1636 - po 1700) - syn Isaja Serhiowicza (zmarłego bez testamentu między 4 marca a 25 października 1651 podczas zarazy ${ }^{249}$, przysięgłego od ok. 1647 do śmierci, mającego dom na ul. Długiej w jurysdykcji ruskiej ${ }^{250}$ ), bratanek Zachariasza (przed 1652) i Magdy ${ }^{251}$. Podczas zarazy, kiedy zmarł jego ojciec, wtedy już wdowiec, był nieletni i w 1651 roku sąd wyznaczył trzech opiekunów do spraw sukcesji: Mikołaja Markiewicza ${ }^{252}$, Bogdana Ballowicza (Balowicza, Balejowicza) ${ }^{253}$, Chodzika Hołubowicza (zob. ${ }^{254}$. Odziedziczył m.in. dom przy ul. Długiej (1652). Był mężem Gertrudy Zarugiewiczówny ${ }^{255}$ (zob. „Lehahayer”, 6, s. 39-40). Z Sozopola (1675) wydelegowany do Porty (Dokument nr 2), w Filibe występował jako ,deputowany” (Dokument nr 7).

Symura [Iskenderowicz] - syn Iskendera, był w Ankarze $(1681)^{256}$.

Andrij [Istenkowicz] - syn Istenki (1681) $)^{257}$.

Iwanes - najmita (pachołek) Saruhana [Muradowicza] (zob.) $(1681)^{258}$.

311. Bogdan Iwanisowicz (Owanisowicz) - występował w sprawie sądowej w 1653 roku $^{259}$, w latach 1660-1663 jako przysięgły ${ }^{260}$. W Filibe, w 1675 i 1676 roku, pełnił funkcję oficjalisty (Dokument nr 7, nr 12, nr 16).

${ }^{242}$ BZNiO: sygn. 1590/II, Akta sądu ormiańskiego w Stanisławowie z lat 1692-1702, 1696 r.: s. 363-364, 392, 414; 1698 r.: s. 606.

243 B. Czart.: sygn. 3543 IV, k. 7v, 11-11v, 13, 15, 17 (jako „X Nierses Thomasz Hołubowicz"), 19v, 21.

${ }^{244}$ BZNiO: sygn. 1590/II, Akta sądu ormiańskiego w Stanisławowie z lat 1692-1702, s. 613.

${ }^{245}$ Metryka, s. 579, 581, 584.

${ }^{246}$ LNNBU: sygn. f. 5, op. 1, spr. 1360/III Księga Akt Orm., s. 143.

247 K. Stopka, Wykaz duchowieństwa.

248 BZNiO: sygn. 1732/II, Protocollum actorum consistorii, k. 54v-55.

249 ЦДІАУ: f. 39, op. 1, spr. 158, k. 62.

250 Ibidem, k. 95v-96.

251 Ibidem, k. 96.

252 Ibidem, k. 62.

253 А. Н. Гаркавец, Кыпчакское письменное наследие, s. 953.

${ }^{254}$ ЦДІАУ: f. 39, op. 1, spr. 158, k. 95v-96.

${ }^{255}$ FKiDOP: sygn. 9/36, Liber defunctorum parochianorum Stanislanoviensium, s. 23.

256 D. Kołodziejczyk, The Ottoman Survey, s. 88.

257 Ibidem, s. 89.

258 Ibidem.

259 ЦДІАУ: f. 39, op. 1, spr. 41, k. 14.

${ }^{260}$ Ibidem, spr. 42, k. 252. 
166. Mikołaj Iwanisowicz - członek kamienieckiego bractwa Świętego Michała Archanioła $^{261}$.

226. Jakub Iwanisowicz Kurkulis - syn Iwanisa Kurkulisa i Anny Kurkuliski (zob.), brat: Piotra ${ }^{262}$, Zofii Butachowiczowej $(\dagger 1653)^{263}$, żony Bogdana Butachowicza (zob.), Róży Ajzbejowiczowej ${ }^{264}$, Marusi († 1653) ${ }^{265}$. W 1675 roku w Filibe brał pieniądze: „moim y Matki y siostry moich imieniem” (Dokument 13).

Iwas - służący (pomocnik) piekarza Manuga [Matiaszewicza] (zob.) (1681) ${ }^{266}$.

Iwas - (inny od wyżej wymienionego?) służący (pomocnik) piekarza Manuga [Matiaszewicza] (zob.) $(1681)^{267}$.

Kirkor Iwaszkiewicz - w Filibe w 1676 roku otrzymał pieniądze (Dokument nr 13).

145. Iwaszkowiczówna (Iwasówna) - córka Iwaszki Gogczewicza.

Anna Magdalena Szymonówna Jahudówna (ur. 21 stycznia 1695 we Lwowie) - córka Szymona $^{268}$ (zob. „Lehahayer”, 6, s. 40).

Marianna Anna Szymonówna Jahudówna (ur. 20 czerwca 1685 we Lwowie) - córka Szymona $^{269}$ (zob. „Lehahayer”, 6, s. 40). Jej chrzestnym był Bernat Isajowicz (zob.).

Jakub († po 1699) - ożenił się w 1695 roku we Lwowie z Marianną Budzanowską, prawdopodobnie ten sam był świadkiem na ślubie Anny Cartumelówny (zob.) we Lwowie w 1699 roku $^{270}$.

172. Bogdan (Aswadur) Jakubowicz - w 1677 roku w Filibe był delegatem do posła polskiego w Porcie (Dokument nr 17).

Bohos Jakubowicz $(†$ 1697/1699) - starszy syn Jakuba Bohosowicza (zob.), mąż Ulchatunki, wcześniej żony Azbeja Mitkiewicza i ojczym jej syna, Mitka Azbejowicza ${ }^{271}$, ojciec Dżaszchatun Lusigowej (zob.). W 1684 roku w Stanisławowie zobowiązał się do opieki nad ciotką, Marianną Bohosowiczówną (zob. „Lehahayer”, 6, s. 2628), w zamian za jej dom. Ostatni raz w księdze sądu stanisławowskiego występuje w $1697 \mathrm{roku}^{272}$.

Gabriel Jakubowicz - młodszy syn Jakuba Bohosowicza (zob.), został wykupiony z niewoli tatarskiej ${ }^{273}$.

Lewonostaryk (?) [Jakubowicz] - syn Jakuba [Somonowicza] (zob.) $(1681)^{274}$.

174. Mikołaj Jakubowicz ( $\dagger$ przed $1673^{275}$ ) - syn Zofii i Jakuba Lewonowicza ${ }^{276}$ $\left(\dagger 1644^{277} / 1654\right)$, po których odziedziczył dom przy Rynku Ormiańskim, między

\footnotetext{
${ }^{261}$ BZNiO: sygn. 1732/II, Protocollum actorum consistorii, k. 43v, 92.

${ }^{262}$ ЦДІАУ: f. 39, op. 1, spr. 158, k. 139v.

263 Ibidem, k. 200v-201.

${ }^{264}$ Ibidem.

265 Ibidem, spr. 41, k. 12v.

${ }^{266}$ D. Kołodziejczyk, The Ottoman Survey, s. 90.

267 Ibidem.

${ }^{268}$ Metryka, s. 508.

269 Ibidem, s. 490.

270 Ibidem, s. 509-510.

271 BZNiO: sygn. 1590/II, Akta sądu [...] w Stanisławowie z lat 1692-1702, s. 655.

272 Ibidem, s. 476.

273 BZNiO: sygn. 1732/II, Protocollum actorum consistorii, k. 96.

274 D. Kołodziejczyk, The Ottoman Survey, s. 87.

275 BZNiO: sygn. 1732/II, Protocollum actorum consistorii, k. 72v.

276 ЦДІАУ: f. 39, op. 1, spr. 41, k. 227v.

277 А. Н. Гаркавец, Кыпчакское письменное наследие, s. 933.
} 
domem wdowy Owanisowejej78 a kamienicą Chodzika Hołubowicza ${ }^{279}$. Brat Szymona [Caruka] ${ }^{280}$, męża Róży Kirkorowiczówny; brat prawdopodobnie też Lewona $(†$ 1646/1651), pierwszego męża Zuzanny z Pirumowiczów Nurinowiczowej. Prawdopodobnie tożsamy z zięciem Marka Serhiowicza ${ }^{281}$. Rymarz i współspadkobierca Isaja Serhiowicza, brata Marka ${ }^{282}$.

175. Zachariasz Jakubowicz († przed 1690) - w 1675 roku w Sozopolu, razem z Muradem Seferowiczem, był odpowiedzialny za przedmioty wywiezione z Kamieńca, z kościołów ormiańskich (Dokument nr 1), wydelegowany z Sozopola do Porty (Dokument nr 2), był oficjalistą (Dokument nr 3, nr 5, nr 6, nr 7), w Filibe w 1675 roku - także jako oficjalista wydelegowany z supliką do sułtana (Dokument nr 8) i w 1677 roku $^{283}$. Prawdopodobnie tożsamy z kupcem, który w spółkę handlową z Krzysztofem Damenesztem Bogdanowiczem zainwestował dużą sumę 1600 talarów lewkowych $(1655)^{284},(1660)^{285}$.

346. Zachariasz Jakubowicz Sakulczyk (Sakułowicz) - syn Sakuły (1641) ${ }^{286}$, ojciec Awedyka [Sakułowicza Zachariaszewicza / Zadykiewicza], złotnik (1654 i później) ${ }^{287}$. Sąd stanisławowski miał dochodzić (1685) jego długu zaciągniętego na wygnaniu w Filibe ${ }^{288}$.

Murad [Janowicz] - syn Jana $(1681)^{289}$.

Gresko (Grzegorz) Janowicz Litwinicz (ur. 13 marca 1679 we Lwowie) - syn Jana Litwinicza ${ }^{290}$ (zob. „Lehahayer”, 6, s. 47).

Katarzyna Helena [Janowiczówna, Owanesowiczówna] (ur. 22 sierpnia 1685 we Lwowie) - córka Jana Mikołajowicza ${ }^{291}$ (zob.).

Marcella Elżbieta [Janowiczówna] (ur. 18 stycznia 1690 we Lwowie) - córka Jana Mikołajowicza ${ }^{292}$ (zob.).

Aleksza [Jasykowicz, Jazykowicz] - syn Jasyka, brat Inagoczmy (zob.) (1681) ${ }^{293}$. Inagomcza (Inakomcza?) [Jasykowicz, Jazykowicz] - syn Jasyka, brat Alekszy (zob.) $(1681)^{294}$.

Dawid [Jisajowicz] - syn J[i]sa, brat Mikajela (zob.) $(1681)^{295}$.

278 ЦДІАУ: f. 39, op. 1, spr. 41, k. 49v.

279 Ibidem, k. 77.

${ }^{280}$ Ibidem, k. 229v.

281 Ibidem, spr. 158, k. 159v.

282 Ibidem, k. 114.

283 BN: sygn. Rps Akc. 12904, k. 8.

${ }^{284}$ ЦДІАУ: f. 39, op. 1, spr. 41, k. 131v-132.

285 Ibidem, k. 160.

286 А. Н. Гаркав ец, Кыпчакское письменное наследие, s. 932.

${ }^{287}$ ЦДІАУ: f. 39, op. 1, spr. 41, k. 110v.

288 BZNiO: sygn. 1732/II, Protocollum actorum consistorii, k. 24.

289 D. Kołodziejczyk, The Ottoman Survey, s. 89.

${ }^{290}$ Metryka, s. 466.

291 Ibidem, s. 491.

292 Ibidem, s. 491, 505.

${ }^{293}$ D. Kołodziejczyk, The Ottoman Survey, s. 89.

294 Ibidem.

295 Ibidem. 
Mikajel [Jisajowicz] - syn J[i]sa, brat Dawida (zob.) (1681) ${ }^{296}$.

23. Elżbieta (Helżbieta) Muradówna 1v. Asłanowiczowa, 2v. Jołczowiczowa - żona Zachariasza Asłanowicza (zob. „Lehahayer”, 6, s. 19) i Zachariasza Jołczowicza ${ }^{297}$. Na potrzeby zakładników lwowskich, przetrzymywanych od 1672 roku w Kamieńcu, pożyczyła, podobnie jak Zofia Balewiczowa (zob.), 20 talarów lewkowych. Zrzekła się tej sumy, odzyskanej przez Grzegorza Miłkiewicza (zob.), i w 1682 roku, mieszkając już w Stanisławowie, przeznaczyła ją na kościół ormiański stanisławowski i lwowski klasztor benedyktynek ormiańskich, by te modliły się za duszę jej zmarłego męża ${ }^{298}$.

167. Łukasz Jołczunowicz (nie Jaghczunowic) $(† 1677 / 1678)^{299}$.

Margareta Jołczunowiczówna (ur. 4 września 1678 we Lwowie) - urodzona po śmierci ojca, Łukasza Jołczunowicza (zob.).

Arwasyn (?) [Kadmosowicz] - syn Kadmosa (1681) ${ }^{300}$.

Hiudawirdi [Kajtmasowicz] - syn Kajtmasa z Wank $(1681)^{301}$.

196. Krzyśko Kieresz - w Filibe w 1676 roku odebrał pieniądze także w imieniu siostry, żony Stefana: ,y tez imieniem siostry moię Stephanowy [por. Rozalia Dryngaczowa] wdowy podpis[uję się]” (Dokument nr 13).

Iwaszko Jurkiewicz Kieworowicz († po 1663) - syn Jurka Kieworowicza, brat Mikołaja (zob.). W 1653 roku wraz z żoną, Justyną Jakubowiczówną (zob.) (ślub ok. 1633), bezdzietni, ustanawiają się nawzajem swoimi spadkobiercami ${ }^{302}$. Wójt (od $1651^{303}$ do 1655$)$, przysięgły ( $1646^{304}$ i od $\left.1656^{305}\right)$.

Mikołaj (Misko) Jurkiewicz Kieworowicz - syn Jurka Kieworowicza, brat Mikołaja (zob.), drugi mąż Anny Iwanisówny ${ }^{306}$ (zob.), członek Rady Czterdziestu Mężów ${ }^{307}$, przysięgły (od 1653) $)^{308}$, starszy (1653-1654) (109 $^{309}$,succolector” czopowego i akcyzy $(1658)^{310}$. Wspólnie z żoną mieli dom w jurysdykcji polskiej, między placem / domem Warteresa Serhiowicza a domem Kudliczowskim, należącym do kapituły kamienieckiej ${ }^{311}$. W 1656 roku stanął w obronie żony, która posądzona była o czary,

296 Ibidem.

297 BZNiO: sygn. 1359/II, Akta sądu [...] w Stanisławowie 1681-1689, s. 161-163: ,sławetna Helżbieta Muradowna niegdy sławetnego Zachariasza Asłanowicza mieszczanina y kupca kamienieckiego pierwszego małzęstwa, wtorego zaś Zachariasza Jołczowicza Ormianina mieszczanina y kupca stanisławowskiego Małżąka".

298 Ibidem, s. 162-163.

299 Metryka, s. 477.

300 D. Kołodziejczyk, The Ottoman Survey, s. 89.

301 Ibidem, s. 88.

302 ЦДІАУ: f. 39, op. 1, spr. 41, k. 15v.

${ }^{303}$ Ibidem, spr. 158, k. 72v.

304 А. Н. Гаркавец, Кыпчакское письменное наследие, s. 934.

305 ЦДІАУ: f. 39, op. 1, spr. 41, k. 208.

306 Ibidem, spr. 158, k. 49v.

${ }^{307}$ Ibidem, k. $72 \mathrm{v}$.

${ }^{308}$ Ibidem, spr. 41, k. 46.

309 Ibidem, k. 53v.

${ }^{310}$ Ibidem, spr. 42, k. 84v.

${ }^{311}$ Ibidem, spr. 41, k. 128v-129; spr. 42, k. 129v. 
jak mówił przed sądem: „w niebytnosci moiey, na tenczas w sprawach publicznych wszystkiego miasta [Kamieńca] we Lwowie za Dworem K[róla] J[ego] M[o]sci zostaiącego" 312 .

Anna Iwanisówna Kieworowiczowa - córka Róży i Owanka Chingigowiczów († przed 1651), właścicieli domu koło kamienicy Beznosowskiej ${ }^{313}$, siostra Gertrudy Serhiowiczowej $(\dagger 1651)^{314}$. Jej pierwszym mężem był prawdopodobnie [Krzysztof] Tatułowicz, z którym miała syna, Zachariasza Krzysztofowicza (zob.) ${ }^{315}$. Jej drugim mężem był Mikołaj Kieworowicz (zob.), często pojawiała się w księgach sądowych w sprawach finansowych. Pod nieobecność męża, w 1656 roku, została niesłusznie - jak orzekł sąd - posądzona przez Kirkora Megerdyczowicza (zob.) o czary, które miały mu szkodzić ${ }^{316}$.

Justyna Jakubowiczówna Kieworowiczowa († po 1663) - siostra Iwaszki Jakubowicza $(1653)^{317}$, żona Iwaszki Kieworowicza (zob.).

Kirikor - diak $(1681)^{318}$.

Aswadur (Bogdan) [Kirkorowicz] - syn Kirikora, brat Sahaga (zob.) (1681) ${ }^{319}$.

Sahag [Kirkorowicz] - syn Kirikora, brat Aswadura (zob.) $(1681)^{320}$.

199. Jan (Owanis) Kirkorowicz - w wykorzystywanych w tym artykule księgach sądowych kamienieckich (czyli od 1651 do 1663 roku) występuje kilku Kirkorowiczów o imieniu Jan. Ponieważ odmiany tego imienia nie są konsekwentnie stosowane w odniesieniu do tych samych osób, to przy mnogości Janów Kirkorowiczów trudno jest ustalić, który z nich jest którym Janem Kirkorowiczem i w związku z tym nie wiadomo, który dożył omawianego tu okresu ostatniej ćwierci XVII wieku. Wydaje się, że jednak warto ich wymienić:

Awak Kirkorowicz (Ut\$Łn々hp - Seferczyk) - siostrzeniec Aschapetki Putretowiczowej (zob.), który dziedziczył po bezpotomnej śmierci jej męża, Kirkora Putretowicza $(1652)^{321}$. Nie ma pewności, czy tożsamy z Awakiem Kirkorowiczem († 1654), ojcem Róży Krzysztofowiczowej (zob.) i Krzysztofa Owakowicza, który ożenił się we Lwowie w 1645 roku $^{322}$, Heleny 1v. Krzysztofowiczowej, 2v. Seferowiczowej (zob.), Grzybowskiej (zob.). Nie wiadomo, czy tożsamy z Awakiem Kirkorowiczem, właścicielem domu w sąsiedztwie domu Marydrosa Donawakowicza (1657);

Jasko Kirkorowicz (Gjuuuhq, Euupo - Jasin, Jasko) († po 1655) - mąż Marianny Muratówny († przed 1655);

Jasko Kirkorowicz († po 1656) - może tożsamy z wyżej wymienionym Jaskiem; brat Torosa, szwagier Marty (pierwszy mąż - Mysyr Serhiowicz; drugi mąż, z którym uzyskała rozwód, Toros Kirkorowicz);

312 Ibidem, k. 220v.

313 Ibidem, spr. 42, k. 244v.

${ }^{314}$ Ibidem, spr. 158, k. 75-75v.

315 Ibidem, spr. 41, k. $155 \mathrm{v}$.

316 Ibidem, k. 196v-198.

317 Ibidem, k. 15v.

318 D. Kołodziejczyk, The Ottoman Survey, s. 88.

319 Ibidem.

320 Ibidem.

321 ЦДІАУ: f. 39, op. 1, spr. 158, k. 133-133v.

${ }^{322}$ Ibidem, k. 104v. 
Owanko Kirkorowicz - mąż Anny Krzysztofówny (1654);

Ohan [Kirkorowicz] - syn Kirkora (1681) ${ }^{323}$;

Jan (Owanis) Kirkorowicz - w 1676 roku w Filibe otrzymał pieniądze (Dokument nr 13); możliwe, że tożsamy z Janem (Owanisem) Kirkorowiczem († 1688/1700) (zob. „Lehahayer", 6, s. 43).

203. Megerdycz Kirkorowicz - syn Maruchny (zob.) i Kirkora Megerdyczowiczów. W sądzie zeznawał w 1661 roku $^{324}$. W 1676 roku w Filibe odebrał pieniądze, ,imieniem Matki moiey y Tumanowey" (Dokument nr 13).

199. Ohan (Jan) Kirkorowicz - zakrystianin kościoła św. Michała (1653) ${ }^{325}$, oskarżany o to, że pożar z jego stajni rozprzestrzenił się na dom sąsiada, Rusina, Bazylego Przybojańskiego (1656). W 1662 roku skonfliktowany z Dymitrem Mikołajewiczem, przysięgłym ruskim ${ }^{326}$.

205. Wartan Kirkorowicz - syn Szczęsnej Mikołajówny i Kirkora Jakubowicza, brat Axenta i Mikołaja (1651), pisarz, przysięgły ${ }^{327}$ i wójt ${ }^{328}$. Mąż Steckiewiczówny (siostry Szymona i Grzegorza ze Lwowa, $† 1661)$, ojciec (zob.): Marianny i Anny ${ }^{329}$.

95. Krzysztof Kirkorowicz Cekielski - syn Zofii ( $†$ po 1659, miała dom przy ul. Długiej) i Kirkora († przed 1654) Cekielskich, brat kleryka Sahaga (1659) ${ }^{330}$. W 1676 roku w Filibe występował jako przedstawiciel Rady Czterdziestu Mężów (Dokument nr 11, nr 12, nr 13).

Grzegorz [Kirkorowicz] Karakasz - w latach 50. XVII wieku związany ze Lwowem ${ }^{331}$, w 1655 roku - działał w Kamieńcu, prawdopodobnie tożsamy z: Grzegorzem Karakaszowiczem, który znalazł się w 1676 roku w Filibe (Dokument nr 11), i z mężem Zofii Karakaszowej (zob. „Lehahayer”, 6, s. 42-43).

363. Jakub Kirkorowicz Sirutka († ok. 1693) - syn Marencji Kirkorowej, mąż Anny, krawiec. Pojawił się na kartach sądu ormiańskiego w Kamieńcu już w 1652 roku. Przy takim samym imieniu i nazwisku kilkukrotnie pojawia się przydomek Sirutka w latach 1662-1676. Był w Filibe w 1676 roku jak przedstawiciel Rady Czterdziestu Mężów przy rozliczeniu wyjazdu do Adrianopola i do Porty (Dokument nr 11, nr 12). Możliwe, że ten sam od 1678 roku był rajcą ormiańskim w Stanisławowie, a w 1689 roku - wójtem.

Mariam Kirkorowiczowa - córka Zachariasza Romaszkiewicza (zob.), żona Agopa Kirkorowicza z Horodenki ${ }^{332}$.

Anna Kirkorowiczówna - córka Wartana Kirkorowicza (zob.) (1662) $)^{333}$.

Marianna Kirkorowiczówna - córka Wartana Kirkorowicza (zob.) (1662) ${ }^{334}$.

${ }^{323}$ D. Kołodziejczyk, The Ottoman Survey, s. 88.

324 ЦДІАУ: f. 39, op. 1, spr. 42, k. 213.

325 Ibidem, spr. 158, k. 198.

326 Ibidem, spr. 42, k. 242-242v.

327 Ibidem, spr. 158, k. 52-52v.

${ }^{328}$ Ibidem, spr. 42, k. 252.

329 Ibidem, k. 231-231v.

330 Ibidem, k. 121.

331 Ibidem, spr. 41, k. 136v.

332 B. Czart.: sygn. 3543 IV, k. 118v.

333 ЦДІАУ: f. 39, op. 1, spr. 42, k. 231-231v.

334 Ibidem, k. 231-231v. 
Marta Kirkorowiczówna (Kirkorówna) (ur. 24 stycznia 1679 we Lwowie) - córka Grzegorza Szymonowicza ${ }^{335}$ (zob. „Lehahayer”, 6, s. 61).

Owas [Kirysowicz, Girysowicz] - syn Kirysa, był u Porty $(1681)^{336}$.

Aswadur (Bogdan) [Konaszowicz] - syn Konasza, był u Porty $(1681)^{337}$.

Szahin [Kristowicz] - syn Krista, był u Porty $(1681)^{338}$.

Krzysztof - ożenił się z lwowianką Urszulą 8 listopada 1689 roku $^{339}$.

Giragos [Krzysztofowicz] - Kirakos, syn Chaczadura, ojciec Nikogosa (zob.) (1681) ${ }^{340}$. Hanko [Krzysztofowicz] - syn Chaczadura (1681) $)^{341}$.

212. Jakub Krzysztofowicz - brat Zofii Patrałowiczowej ${ }^{342}$, rzeźnik, członek bractwa rzeźniczego jurysdykcji ormiańskiej $(1654)^{343}$, stawał w sądzie w 1652 roku.

Kadmos [Krzysztofowicz] - syna Chaczadura $(1681)^{344}$.

209. Krzysztof Krzysztofowicz - ksiądz, prawdopodobnie tożsamy z ks. Krzysztofem Krzysztofowiczem, obecnym w 1676 roku w Filibe (Dokument nr 12, nr 16).

7. Mikołaj (Michno) Ajsko (Aÿsko) Krzysztofowicz - syn Ajski Krzysztofowej $\left(\dagger 1655^{345}\right)$, pojawiał się w sądzie ormiańskim kamienieckim w 1655 roku ${ }^{346}$ i prawdopodobnie w następnych latach $(1660)^{347}$. W 1676 roku w Filibe był przedstawicielem Rady Czterdziestu Mężów (Dokument nr 12).

Serhij (Serhy) Krzysztofowicz - brat Róży, „porucznikowej” (1652); mąż Anny, córki Jołbeja Hankowicza $(\dagger 1652)^{348}$. Prawdopodobnie ten sam w 1676 roku w Filibe otrzymał pieniądze (Dokument nr 13).

Zachariasz Krzysztofowicz - syn prawdopodobnie [Krzysztofa] Tatułowicza i Anny Iwanisówny Kieworowiczowej (z jej pierwszego małżeństwa, zob.) (1655) ${ }^{349}$.

217. Zachariasz Krzysztofowicz Beznosy ( $†$ 1663/1673) - najmłodszy syn Anny Deriwanisówny i Krzysztofa Beznosego Kirkorowicza, przysięgłego ${ }^{350}$, wuj Jerzego Krzysztofowicza $^{351}$ (zob. „Lehahayer”, 6, s. 45). Jego matka († ok. 1655 ${ }^{352}$ ), w 1654 roku, po śmierci syna, Iwaszki (1652), przypadającą jej część spadku po nim w całości przekazała Zachariaszowi, odmawiając prawa do spadku trzeciemu synowi, Szymonowi († wrzesień 1654) 353 , i oświadczyła w testamencie, że mu „duszę y ciało

${ }^{335}$ Metryka, s. 465.

336 D. Kołodziejczyk, The Ottoman Survey, s. 88.

337 Ibidem.

338 Ibidem, s. 89.

${ }^{339}$ Metryka, s. 501.

${ }^{340}$ D. Kołodziejczyk, The Ottoman Survey, s. 89.

341 Ibidem.

342 ЦДІАУ: f. 39, op. 1, spr. 41, k. 23.

${ }^{343}$ Ibidem, k. 85-85v.

344 D. Kołodziejczyk, The Ottoman Survey, s. 89.

345 ЦДІАУ: f. 39, op. 1, spr. 41, k. 144-144v.

346 Ibidem, k. 144-144v.

347 Ibidem, spr. 42, k. $168 \mathrm{v}$.

348 Ibidem, spr. 158, k. 112v, 175-175v.

349 Ibidem, spr. 41, k. 155v.

${ }^{350}$ Ibidem, k. 64v.

351 Ibidem, spr. 42, k. 223v.

352 Ibidem, spr. 41, k. 141v.

353 Ibidem, k. 56v. 
swoie zleca, aby tak za zywota ią opatrował, iako y po smierci o dusze iey zbawienie starał sie" ${ }^{354}$. Jego siostra była żoną Krzysztofa Wartanowicza (zob.) (1662) ${ }^{355}$. Mąż Zofii Kieworowiczówny (zob.) (1662) $)^{356}$, przysięgły od 1651 roku $^{357}$, prowizor kościołów ormiańskich kamienieckich $\left(1656^{358}, 1663^{359}\right)$. W 1654 roku w Warszawie pożyczył przedstawicielowi kamienieckiego cechu rzeźnickiego pieniądze na zakup ponad stu skór przeznaczonych najprawdopodobniej na łapówkę dla królewskich urzędników w sporze z rzeźnikami polskimi w Kamieńcu ${ }^{360}$. Wraz z żoną spadkobierca kamienicy Beznosowskiej ${ }^{361}$. Darowana przez niego Kościołowi monstrancja przeznaczona została w 1675 roku w Filibe na spieniężenie (Dokument nr 3, nr 8, nr 11, nr 16).

Bogdan Krzysztofowicz Dryngacz (Drengacz) - syn Marianny 2v. Ballowiczowej i Krzysztofa Dryngacza. Miał dług u Isaja Bohosowicza (zob.), który procesował się z nim w Stanisławowie $(1703)^{362}$. Możliwe, że ten sam ofiarował kapy, gremiały i kilim do kościoła ormiańskiego w Stanisławowie ${ }^{363}$. Możliwe też, że tożsamy z Bogdanem Dryngaczem, mężem Marty, z którą mieszkał od około 1707 roku w Horodence, gdzie rodziły im się dzieci ${ }^{364}$.

Łukasz Krzysztofowicz Egzemper (tylko po orm. Łlqqứphp) - mąż Róży Owakowiczówny (zob.), pisarz sądowy (1653-1661) $)^{365}$, przysięgły $(1666)^{366}$, wójt ${ }^{367}$. Toczył spór sądowy z żoną, skarżąc się, że ona ,z inszemi postronnemi ludzmi bankietuie się, na zdrowie iego nastempuje, kiiem onego, który chowa za drzwami w komnacie, zabic usiluie, a nawet y tricizne w grzebkach niedawnemi czasy dała była" ${ }^{368}$. Około 1654 roku jechał do Turcji w poselstwie wojewody sandomierskiego Władysława Myszkowskiego (1650-1656) ${ }^{369}$.

215. Szymon Krzysztofowicz Jasil, Jaszil, Zieliński (tuz $2 \mathrm{hl}$ - zielony) († po $1685^{370}$ ) brat przyrodni Warteresa Warteresowicza (zob.) $)^{371}$; mąż Róży Hołubówny (1651),

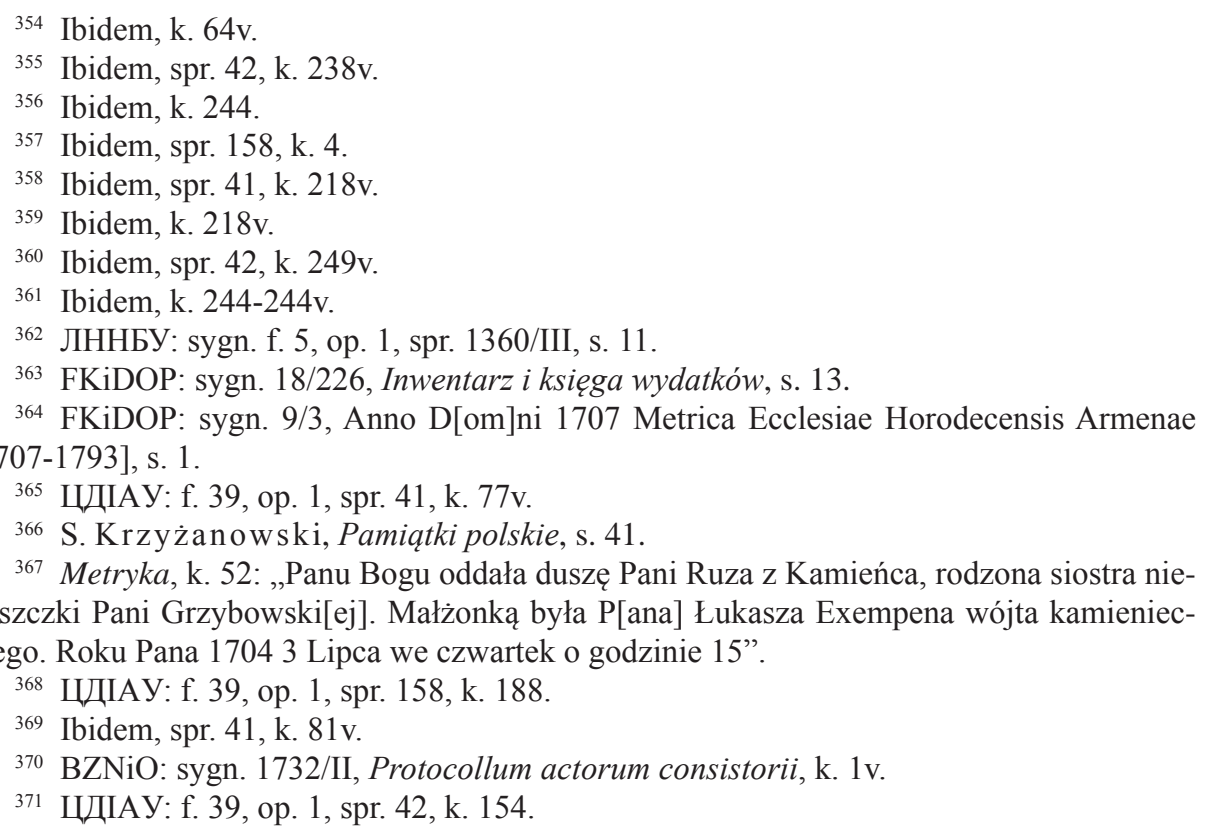


z którą miał dom koło domu Pierzady Nuridzianowicza ${ }^{372}$; zięć Mikołaja Hanesowicza (zob.) (1655) ${ }^{373}$. W sądzie pojawiał się w latach następnych. W 1675 roku ofiarowany przez niego „krzyz wielki srebrny zlocisty” należał do dóbr Kościoła, którymi dysponowali wygnańcy w Sozopolu (Dokument nr 3). Był przy rozliczaniu delegacji do Adrianopola (Dokument nr 6).

187. = prawdopodobnie 186. i 213. Jan (Jasko) Krzysztofowicz Kapaczyk (Kapacz, Kopacz) - syn [Krzysztofa Kapacza], siostrzeniec Szymona Łukaszewicza ${ }^{374}$ (zob.), brat Anny Kapaczykówny Axentowej (zob.) $)^{375}$, szwagier Jana Bobrykiewicza ${ }^{376}$ (zob.). Drugi mąż Elżbiety (Halszki) Mikołajówny, z którą w 1651 roku odnajęli część domu, zostawiając sobie „domek mały w sieniach będący iako y piekarnię”377. Ojczym i opiekun Augustyna Seferowicza ${ }^{378}$. Wielokrotnie występował w sądzie w latach 1651-1663. Porywczy, za co dwa razy miał sprawy przed sądem gajonym kryminalnym na ratuszu ormiańskim. Pierwsza sprawa w 1652 roku była „o zgwałcenie mieysca publicznego y uprziwileiowanego Ratusza Ormianskiego, także o despektowanie i pobicie delatora" ${ }^{379}$, w której, pismem królewskim, został oczyszczony z zarzutów i zwolniony z kary banicji ${ }^{380}$. Druga sprawa była w 1656 roku o to, że podczas wesela ,pokoiem pospolitym warowanym”, w domu „urzędniczym”, przysięgłego Chodzika Hołubowicza (zob.) „kiiem zdradliwie uderzyc wazyl się”, za co groziło mu ucięcie prawej ręki ${ }^{381}$. W 1675 roku w Sozopolu, jako jeden z Rady Czterdziestu Mężów, przyjmował rozliczenie finansowe delegatów wracających z misji do Adrianopola i Janpola, a ponad rok później, w Filibe, już bez określonej funkcji - delegatów do Adrianopola (Dokument nr 6 i nr 11). W Filibe, w 1676 roku, odebrał pieniądze ,imie[niem] teszczy moiey y Bachczynskiey (zob.)"382.

216. Zachariasz Krzysztofowicz Mliczkowski (Uolopu, czyt. Mołoka) - mąż Zofiii ${ }^{383}$; obecny był w sprawach sądowych od 1652 roku.

221. Zofia Kieworowiczówna (Jurkiewiczówna - nie Juśkiewiczówna, jak podałam w „Lehehayer”, 6) Krzysztofowiczowa Beznosina († 14 czerwca 1691 we Lwowie $^{384}$ ) - prawdopodobnie córka Jurka Kieworowicza, siostra Kieworowiczów

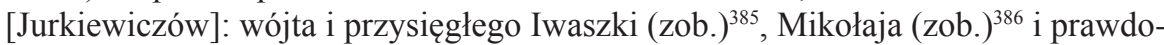
podobnie Katarzyny Romaszkiewiczowej; żona Zachariasza Beznosego Krzysztofowicza (zob.) (1662) $)^{387}$.

372 Ibidem, spr. 158, k. 14.

373 Ibidem, spr. 41, k. 135.

374 Ibidem, k. 253v.

375 BZNiO: sygn. 1732/II, Protocollum actorum consistorii, k. 55.

376 ЦДІАУ: f. 39, op. 1, spr. 41, k. 254.

377 Ibidem, spr. 158, k. 16v.

378 Ibidem, spr. 42, k. 245v-246.

379 Ibidem, spr. 158, k. 155v-156.

${ }^{380}$ Ibidem, spr. 41, k. 26v.

381 Ibidem, k. 253, 255.

382 BN: sygn. Rps Akc. 12904, k. 13.

383 ЦДІАУ: f. 39, op. 1, spr. 158, k. 196v.

384 Metryka, s. 525: „1691 Czerwca 14. Pani Beznosina Panu Bogu oddała duszę”.

385 А. Н. Гаркавец, Кыпчакское письменное наследие, s. 936.

386 Ibidem, s. 951.

387 ЦДІАУ: f. 39, op. 1, spr. 42, k. 244. 
Róża Owakowiczówna (Owakówna) Krzysztofowiczowa (nie, jak podałam w „Lehahayer", 6, Hołubowiczowa) Exemperowa (Egzemperowa) († 3 lipca 1704 we Lwowie $^{388}$ ) - wnuczka Caryka Beznosego Krzysztofowicza ${ }^{389}$, córka Anny Carykówny ${ }^{390}$ i Owaka Kirkorowicza, siostra: Krzysztofa Owakowicza ${ }^{391}$, Heleny 1v. Krzysztofowiczowej, 2v. Seferowiczowej (zob.), Grzybowskiej (zob.); żona Łukasza Krzysztofowicza Egzempera (zob.).

225. Zofia Kumpelówna (Kumplówna) - „dewotka”, czyli mniszka (Dokument nr 13).

229. Anna Kurkuliska - żona Iwanisa Kurkulisa (zmarłego ok. 1653 roku szewca, starszego, 1618 ${ }^{392}$ ), matka Kurkulisów Iwanisowiczów: Jakuba (zob.), Piotra, męża Horpyny, który w 1652 roku siedział w więzieniu za długi ${ }^{393}$, Zofii Butachowiczowej $(† 1653)^{394}$, żony Bogdana Butachowicza (zob.), Róży Ajzbejowiczowej ${ }^{395}$ od 1653 roku żony Kirkora ${ }^{396}$, Marusi († 1653), która miała córkę, Nastkę, żonę Rusina Hryćka Jaskowicza ${ }^{397}$. W 1675 roku w Filibe była razem ze swoim synem Jakubem Kurkulisem Iwanisowiczem (Dokument 13), córką i synową, prawdopodobnie tożsama z Kurkuliską „starą” (zob. „Lehahayer”, 6, s. 46).

Kuryłowa - prawdopodobnie żona Kuryły, złotnika (zob. „Lehahayer”, 6, s. 47), w 1676 roku w Filibe otrzymała pieniądze (Dokument nr 13).

232. Krzyśko Kuryłowicz - w 1676 roku w Filibe jeden z przyjmujących rozliczenie delegacji do Adrianopola (Dokument nr 11). Możliwe, że tożsamy z występującym w sądzie w 1660 i 1663 roku z przydomkiem Kamiński ${ }^{398}$, albo - co bardziej prawdopodobne - z mieszkańcem Stanisławowa, zmarłym około 1682 roku $^{399}$.

233. Łukasz (Lusyg) Kuryłowicz († po 1670) - syn Guriecha (Kuryły), safiannika $(1644)^{400}$, od ok. 1646 roku mąż Róży ${ }^{401}$ (zob.), rzeźnik i starszy bractwa rzeźnickiego $(1654)^{402}$, brat cechu tabacharskiego $(1653)^{403}$. W 1655 roku zastawił swoje jatki rzeźnickie i uciekł przed długami na kilka lat ${ }^{404}$.

Symo (Szymon) [Kuryłowicz] - ksiądz, syn Kuryły (Girila) (1681) ${ }^{405}$.

${ }^{388}$ Metryka, s. 530: „Panu Bogu oddała duszę Pani Ruza z Kamieńca, rodzona siostra nieboszczki Pani Grzybowski[ej]. Małżonką była P[ana] Łukasza Exempena wójta kamienieckiego. Roku Pana 17043 Lipca we czwartek o godzinie 15".

389 ЦДІАУ: f. 39, op. 1, spr. 41, k. 86.

${ }^{390}$ Ibidem, spr. 158, k. $85 \mathrm{v}$.

391 Ibidem, k. 104v.

392 А. Н. Гаркавец, Кыпчакское письменное наследие, s. 909.

393 ЦДІАУ: f. 39, op. 1, spr. 158, k. 139v.

394 Ibidem, k. 200v-201.

395 Ibidem.

${ }^{396}$ Ibidem, k. 200v-201, spr. 41, k. 12v.

397 Ibidem, spr. 41, k. 12v.

398 Ibidem, spr. 42, k. 257.

399 BZNiO: sygn. 1359/II, Akta sądu [...] w Stanisławowie 1681-1689, s. 106.

400 А. Н. Гаркавец, Кыпчакское письменное наследие, s. 933.

${ }^{401}$ ЦДІАУ: f. 39, op. 1, spr. 41, k. 175.

402 Ibidem, k. 85.

${ }^{403}$ Ibidem, k. 82v.

${ }^{404}$ Ibidem, spr. 42, k. 163.

405 D. Kołodziejczyk, The Ottoman Survey, s. 87; por. K. Stopka, Wykaz duchowieństwa - Kuryło Der Zachariaszowicz. 
234. Róża [Gulaf] Muradówna Lusygowa Kuryłowiczowa - córka Murada i Hanuchny $(1656)^{406}$, jej wujem był Mikołaj Markowicz; od ok. 1646 roku - żona Łukasza Kuryłowicza (zob.); występowała w sprawie sądowej w 1661 roku $^{407}$.

Owanes [Lazarowicz, Hazarowicz] - syn Hazara (?) $(1681)^{408}$.

Mykyta [Leskasowicz?] - syn Leskasa (?), był w Ankarze (1681) ${ }^{409}$.

Dżaszchatun Bohosowiczówna Lusigowa - córka Bohosa Jakubowicza (zob.), w 1695 roku w Stanisławowie zaręczyła się z Lusigiem ${ }^{410}$.

Łukasz Lukaszewicz - otrzymał pieniądze w 1676 roku w Filibe (Dokument nr 13).

240. Zachariasz Lukaszewicz (Lusigowicz) - w Filibe w 1676 roku jako przedstawiciel Rady Czterdziestu Mężów (Dokument nr 11, nr 12).

Anna Lukaszewiczowa - córka Bogdana Stefanowicza Roszki (zob.) i Edił z Kamieńca, zaręczyła się z Ohanem Łukaszewiczem z Brzeżan w 1708 roku w Stanisławowie ${ }^{411}$.

242. Rozalia Mikołajówna [Lukaszewiczowa] - córka Mikołaja Sahakowicza Mankulca (zob.), a nie, jak podałam w „Lehahayer”, 6 - Łukaszewicza.

Gregir (?) [Madosowicz] - syn Madosa (1681) ${ }^{412}$.

248. Zachariasz Mandziewicz - wzmiankowany w sądzie w 1655 roku $^{413}$ i prawdopodobnie w 1662 roku.

249. [Żablusia] Mandziewiczowa ( $† 21$ grudnia 1703 we Lwowie $\left.{ }^{414}\right)$ - żona Zachariasza, prawdopodobnie tożsama z Żablusią (zob. „Lehahayer”, 6, s. 48); mieszkała jakiś czas w Jarosławiu $(1696)^{415}$.

Aswadur (Bogdan) [Manugowicz] - syn Manuka $(1681)^{416}$.

Bohos [Manugowicz] - syn Manuka [Matiaszewicza] (zob.) $(1681)^{417}$.

Saruhan [Manulowicz] - syn Manula, był u Porty $(1681)^{418}$.

Aswadur [Manusowicz] - syn Manusa $(1681)^{419}$.

254. $=$ 256. Kirkor Markiewicz (Markowicz, Mardyrosowicz) - tożsamy z Kirkorem Mardyrosowiczem (por. „Lehahayer”, 6, s. 49). W 1676 roku w Filibe otrzymał pieniądze jako Kirkor Markowicz ${ }^{420}$ i był obecny jako przedstawiciel Rady Czterdziestu Mężów przy rozliczaniu wyjazdu do Porty (Dokument nr 12). Możliwe, że tożsamy z Kirkorem, synem Mardyrosa w Kamieńcu, w 1681 roku²1.

406 ЦДІАУ: f. 39, op. 1, spr. 41, k. 175.

407 Ibidem, spr. 42, k. 197v.

408 D. Kołodziejczyk, The Ottoman Survey, s. 89.

409 Ibidem, s. 88.

410 B. Czart.: sygn. 3543 IV, k. 7.

${ }^{411}$ Ibidem, k. 53.

412 D. Kołodziejczyk, The Ottoman Survey, s. 89.

413 ЦДІАУ: f. 39, op. 1, spr. 41, k. 127v.

${ }^{414}$ Metryka, s. 530: „Panu Bogu oddała duszę Pani Żablusia wdowa z Kamieńca, małżonka P[ana] Zachariasza Mandziewica. R[oku] 170321 Grudnia. Ta dusza była nawiedzona, przez siedem lat z łoża nie schodziła”.

415 BZNiO: sygn. 1359/II, Akta sądu [...] w Stanisławowie 1681-1689, s. 435.

416 D. Kołodziejczyk, The Ottoman Survey, s. 89.

417 Ibidem, s. 87.

418 Ibidem, s. 88.

419 Ibidem, s. 89.

${ }^{420}$ BN: sygn. Rps Akc. 12904, k. 13.

${ }^{421}$ D. Kołodziejczyk, The Ottoman Survey, s. 88. 
Krzysztof (Chaczko, Chaczadur) Markiewicz (Markowicz, Mardyrosowicz) - mydlarz (uwuuoush - saponczi, 1652) ) $^{422}$, przed sądem pojawił się m.in. w 1661 roku $^{423}$. Możliwe, że tożsamy z Chaczadurem, synem Mardyrosa, który w 1681 roku przebywał w Tokacie ${ }^{424}$.

259. Zachariasz (Bogdanowicz?) Masiutka (Maksiuta) - w 1676 roku w Filibe reprezentował Radę Czterdziestu Mężów (Dokument nr 11, nr 12).

Manug (Manuk) [Matiaszewicz] Dobroniewski (?) - syn Matejosa, ojciec Bohosa [Manugowicza] (zob.), naczelny piekarz ${ }^{425}$, jego służącymi (pomocnikami) byli (zob.) Iwas i Szahin (1681).

378. Babik Megerdyczowicz Suralnik - przypuszczalnie brat Bohosa (zob.) i Kirkora (zob. Maruchna Megerdyczowiczowa), safiannik, w sądzie notowany w 1651 i 1660 roku, miał dom między domem Jołbeja Łukaszowicza a placem pustym Kirkora Megerdyczowicza ${ }^{426}$.

387. Bohos Megerdyczowicz (Suralnik?) - prawdopodobnie tożsamy z Bohosem Taba-

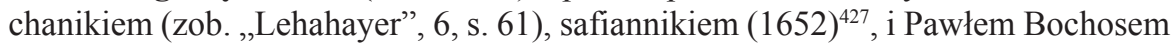
(zob. „Lehahayer”, 6, s. 25); przypuszczalnie brat Kirkora i Babika Megerdyczowicza Suralnika (zob.).

388. Maruchna (Marencja) Megerdyczowiczowa - matka Megerdycza Kirkorowicza (zob.), wdowa po pochodzącym z Wołoszczyzny ${ }^{428}$ Kirkorze $(\dagger 1661-$,jechał na Pokuci i tam zabity od opryszkow zostaje" ${ }^{429}$, safianniku i cechmistrzu, arendarzu wojewody bracławskiego Piotra Potockiego - 1654) ${ }^{430}$. Posiadała z mężem dom między domem potomków Hanka Tumanowicza a domem krawca Bogdana Kuryłowicza $(1652)^{431}$, kram ,między wielkimi kramami” $(1654)^{432}$, dwa młyny $(1658)^{433}$ i pusty plac koło Babika Megerdyczowicza (zob.) (1660). W 1676 roku w Filibe syn w jej imieniu odebrał pieniądze (Dokument nr 13).

Sefer [Melikowicz] - syn Melika $(1681)^{434}$.

Toros [Melikunowicz] - syn Melikuna $(1681)^{435}$.

Minas [Mikajelowicz] - syn Mikjajela $(1681)^{436}$.

Mikołaj - ojciec Jakuba Mikołajewicza (zob.), za pośrednictwem syna otrzymał pieniądze w Filibe w 1676 roku (Dokument nr 13).

Jakub Mikolajewicz - w Filibe w 1676 roku odebrał pieniądze ,imie[niem] Ciotek moich Nalewajkowej [zob. Chatuna Mitkiewiczowa Naliwajkowa] i Simawonowej

${ }^{422}$ ЦДІАУ: f. 39, op. 1, spr. 158, k. 173.

${ }^{423}$ Ibidem, spr. 42, k. 192.

${ }^{424}$ D. Kołodziejczyk, The Ottoman Survey, s. 88.

${ }^{425}$ Ibidem, s. 87.

${ }^{426}$ ЦДІАУ: f. 39, op. 1, spr. 42, k. 151v.

${ }^{427}$ Ibidem, spr. 158, k. 132.

${ }^{428}$ Ibidem, spr. 41, k. 220v-221.

${ }^{429}$ Ibidem, spr. 42, k. 211.

430 Ibidem, spr. 41, k. 79.

431 Ibidem, spr. 158, k. 170v.

${ }^{432}$ Ibidem, spr. 41, k. 72v-73.

${ }^{433}$ Ibidem, k. 82-82v.

${ }^{434}$ D. Kołodziejczyk, The Ottoman Survey, s. 89.

${ }^{435}$ Ibidem.

${ }^{436}$ Ibidem. 
[zob.] podpisuię mpp [...] imieniem P. Oyca moiego podpisuię się mpp" (Dokument nr 13).

273. Jan Mikołajewicz (Mikołajowicz) - we Lwowie urodziły się jego córki: Katarzyna Helena (1685) i Marcella Elżbieta $(1690)^{437}$.

Stefan [Mikołajewicz Bekiesz] (ur. 17 października 1677 we Lwowie) - syn Mikołaja Bogdanowicza Bekiesza i Zofii Talinówny ${ }^{438}$ (zob. „Lehahayer”, 6, s. 23-24).

Bogdan [Mikołajewicz] Karakasz (Kierekieszowski) - syn Marianny i Mikołaja Karakasza Szymonowicza (zob.). W Stanisławowie poświadczał krorąk siostry, Anny, z Bogdanem Bogdanowiczem (1696) (zob. ${ }^{439}$. Prawdopodobnie on był ojcem Mikołaja Karakasza Bogdanowicza (1697-1757).

Jan [Mikołajewicz] Karakasz (Kierekieszowski) Czoban († 10 stycznia 1724) ${ }^{440}-$ syn Marianny i Mikołaja Karakasza Szymonowicza (zob.), mąż Axentowiczówny, córki Axenta Czewadziecha Lazarowicza ${ }^{441}$. Prawdopodobnie ten Jan Mikołajewicz kupił ornat w Filibe, w 1676 lub 1677 roku, który sprzedał później ks. Krzysztofowi Zachnowiczowi, proboszczowi w Stanisławowie ${ }^{442}$. W Stanisławowie był świadkiem spisania krorąku siostry, Anny, z Bogdanem Bogdanowiczem (1696) (zob.) ${ }^{443}$. Kuśnierz, rajca (1709) ${ }^{444}$. Miał czworo dzieci Owanesowiczów Karakaszów: Mikołaja (1689 - 30 lipca 1735), Bedrosa (przed 1693 - 21 kwietnia 1766), Szymona (16981724) i Zofię Torosowiczową.

Szymon [Mikołajewicz (Mikołajewicz)] Karakasz (Kierekieszowski) († po 1735) syn Marianny i Mikołaja Karakasza Szymonowicza (zob.), mąż Marianny († przed 1720), córki Mikołaja Kirkorowicza i Chatuny Chodzikówny ${ }^{445}$. W Stanisławowie w 1694 roku kupił dom między domami „Czudnowskiego alias Bekiesza” i Żyda Moszki ${ }^{446}$. Był świadkiem spisania krorąków: siostry, Anny, z Bogdanem Bogdanowiczem (zob.) (1696) ${ }^{447}$, i bratanka, Mikołaja (zob.) (1718). Cechmistrz kuśnierski, rajca $(1709)^{448}$. Jego drugą żoną była Rozalia ${ }^{449}$.

Hanusia Mikołajewiczowa (1686-1764) - córka Zachariasza Romaszkiewicza (zob.), żona rajcy stanisławowskiego, Lazara Mikołajewicza Czewadziech, zmarła i została pochowana w Stanisławowie ${ }^{450}$.

${ }^{437}$ Metryka, s. 491, 505.

438 Ibidem, s. 473.

439 B. Czart.: sygn. 3543 IV, k. 17.

440 FKiDOP: sygn. 9/36, Liber defunctorum parochianorum Stanislanoviensium Armenorum [1715-1829], s. 19: „Pan Jan z [rodu] Kerekeszów, nazywany przydomkiem Czoban, syn Nigoły [Mikołaja] z [rodu] Czobanów...".

441 BZNiO: sygn. 1590/II, Akta sądu [...] w Stanisławowie z lat 1692-1702, s. 987.

442 Ibidem, s. 879.

443 B. Czart.: sygn. 3543 IV, k. 17.

444 ЛННБУ: sygn. f. 5, op. 1, spr. 1360/III, s. 436.

445 Ibidem, s. 275.

${ }^{446}$ BZNiO: sygn. 1590/II, Akta sądu [...] w Stanisławowie z lat 1692-1702, s. 254.

447 B. Czart.: sygn. 3543 IV, k. 17.

448 ЛННБУ: sygn. f. 5, op. 1, spr. 1360/III, s. 436.

449 FKiDOP: sygn. 9/24, Liber secundus antiquus baptizatorum et confirmatorum [17031783], s. 28.

${ }^{450}$ Ibidem, sygn. 9/36, Liber defunctorum, s. 67. 
Marianna Mikolajowiczowa - córka Aksenta Siedym Jenzyk (zob.), żona Grzegorza, matka księży: Arutiuna Augustyna ${ }^{451}$ i Stefana Mikołajewiczów, po przeprowadzce rodziców ze Lwowa do Kamieńca oddanych do miejscowej szkoły ormiańskiej ${ }^{452}$. Arutiun, potem absolwent kolegium teatyńskiego we Lwowie i doktor teologii (tytuł uzyskany w Rzymie), po przyjęciu święceń przyjął imię Aksenta i był kolejno księdzem w Kamieńcu, Żwańcu, Kutach, Lwowie, Mohylowie Podolskim i Raszkowie. Stefan, kopista w Kutach, był po bracie drugim proboszczem parafii ormiańskiej w Mohylowie Podolskim ${ }^{453}$.

Anna Pierzadowiczówna Mikołajewiczowa Cyntwarowiczowa (1658 - 13 stycznia 1725 w Stanisławowie ${ }^{454}$ ) - córka Szymona i Anastazji Pierzadowiczów, siostra Tomasza Pierzadowicza (zob.), żona Chacziga Mikołajewicza Cyntwarowicza / Cyntwara, mieszkanka Stanisławowa. Wraz z mężem, bratem i szwagierką pozbywali się udziałów w kamienicy Bogdanowiczowskiej we Lwowie na rzecz Dominika Bogdanowicza i jego żony, Eufrozyny ze Steckiewiczów, w 1689 roku $^{455}$.

Marianna Jakubowiczówna Mikołajewiczowa Cyntwarowiczowa († 1693/1695 w Złoczowie) - córka Jakuba Bohosowicza (zob.), żona Daniela ${ }^{456}$ († po 1703). Razem z mężem sprzedali dom w Stanisławowie w 1689 roku ${ }^{457}$ i przenieśli się do Złoczowa, prawdopodobnie razem z córkami Rozalią i Anną; tam Daniel był rajcą i tam urodził się im syn Jakub $(1693)^{458}$.

Anna Rypsyma Mikołajewiczówna (Mikołajówna) [Baranówna] (ur. 10 lipca 1685 we Lwowie) - córka Mikołaja Owanisowicza Barana ${ }^{459}$ (zob.).

Katarzyna Mikołajewiczówna (Mikołajówna) [Baranówna] (ur. 12 kwietnia 1692 we Lwowie) - córka Mikołaja Owanisowicza Barana ${ }^{460}$ (zob.).

Mikołajowa (?) - teściowa Jana Krzysztofowicza Kapaczyka (zob.), możliwe, że matka Elżbiety Mikołajówny; za nią pieniądze w 1676 roku w Filibe odebrał zięććc1.

Kirkor Milkonowicz - w Sozopolu w 1675 roku był świadkiem spisania przedmiotów kościelnych po śmierci wójta Kuryły Miłkiewicza (Dokument nr 3) i rozliczania delegacji powracającej z Adrianopola (Dokument nr 6), w 1676 roku w Filibe był przy rozliczaniu delegacji (Dokument nr 11) i otrzymał pieniądze (Dokument nr 13).

277. - 289. jest: Milkiewicz, Milkiewiczowa, Milkiewiczówna - powinno być: Miłkiewicz, Miłkiewiczowa, Miłkiewiczówna.

${ }^{451}$ Metryka, s. 191, 247, 515, 567.

452 В. Григорян, История армянских колоний, s. 164-165.

${ }^{453}$ T. Zaleski, Stownik biograficzny duchownych ormiańskokatolickich oraz duchownych rzymskokatolickich pochodzenia ormiańskiego w Polsce w latach 1750-2000, Kraków 2001, s. 77-78.

${ }^{454}$ FKiDOP: sygn. 9/36, Liber defunctorum parochianorum Stanislanoviensium Armenorum [1715-1829], s. 20.

${ }^{455}$ BZNiO: sygn. 1359/II, Akta sądu [...] w Stanisławowie 1681-1689, s. 421-422.

456 Ibidem, s. 91.

${ }^{457}$ Ibidem, s. 418-420.

458 AGAD: sygn. 456/1, Liber metricarum. Ecclesia Armena Zloczoviensis, s. 4, 5, 9.

459 Metryka, s. 491.

${ }^{460}$ Ibidem, s. 541.

${ }^{461}$ BN: sygn. Rps Akc. 12904, k. 13. 
277. Augustyn (Axent) Miłkiewicz (Milkiewicz) († po 1687) - syn Zofii († ok. 1652) i Miłka (Mikołaja) ${ }^{462}$, brat (zob.): Grzegorza ${ }^{463}$, Kuryły i Katarzyny Bartoszowiczowej; mąż Marianny (zob.), córki Zofii i Asłana Emirowiczów ${ }^{464}$ (zob.); ojciec Anny (por. Anna Febronia Miłkiewiczówna). W sądzie występował w różnym charakterze na przestrzeni lat 1655-1661 ${ }^{465}$, członek cechu kramarskiego (1656). W 1675 roku działał w Sozopolu jako przedstawiciel Rady Czterdziestu Mężów (Dokument nr 1, nr 3, nr 5 - powierzono mu część przedmiotów kościelnych, nr 6); w Filibe, w 1675 roku, jako oficjalista (Dokument nr 7), delegat do Konstantynopola i Adrianopola (Dokument nr 11, nr 12) i ponownie w 1677 roku jako delegat do posła polskiego w Porcie (Dokument nr 17).

278. Grzegorz Miłkiewicz (Milkiewicz) (urodzony przed $1612^{466}-30$ marca 1683 we Lwowie $^{467}$ ) - syn Zofii († ok. 1652) i Miłka (Mikołaja) ${ }^{468}$, brat (zob.) Augustyna (Axenta), Kuryły i Katarzyny Bartoszowiczowej. Po śmierci brata, wójta Kuryły, w Sozopolu 25 lutego / 7 marca 1675 roku stał się odpowiedzialny za sprzęty liturgiczne wywiezione z Kamieńca. Sporządził dokładne rozliczenie, które jest przedmiotem niniejszego artykułu. Mąż Jadwigi Minasowiczówny (zob. Jadwiga Miłkiewiczowa). Około 1682 roku odzyskał 40 talarów lewkowych pożyczonych przez Zofię Balewiczową (zob.) i Elżbietę Jołczowiczową (zob.) na potrzeby zakładników lwowskich przetrzymywanych od 1672 roku w Kamieńcu ${ }^{469}$.

280. Kuryło (orm. UnıpŁn - Guriech) Miłkiewicz (Milkiewicz) († 25 lutego / 7 marca 1675 roku w Sozopolu) $)^{470}$ - syn Zofii († ok. 1652) i Miłka (Mikołaja) ${ }^{471}$, brat (zob.): Augustyna (Axenta), Grzegorza i Katarzyny Bartoszowiczowej; mąż Chaczadurówny ${ }^{472}$ (zob.). Był członkiem Rady Czterdziestu Mężów w latach 50. XVII wieku, przysięgłym (1660-1666), starszym (1663), wójtem (od 1661), starszym bractwa św. Anny ${ }^{473}$. Po jego śmierci w Sozopolu jego brat, Grzegorz, sporządził inwentarz rzeczy należących do Kościoła, za które odpowiedzialny był Kuryło (Dokument nr 3).

Chaczadurówna (Krzysztofowiczówna) Miłkiewiczowa († po 1675) - córka Sireny Chaczadurowej, siostra Jakuba Chaczadurowicza (Krzysztofowicza) $(\dagger 1658$, podczas zarazy; miał dom przy ulicy Długiej) $)^{474}$, żona Kuryła Miłkiewicza (zob.), była w 1675 roku w Sozopolu ${ }^{475}$.

\footnotetext{
${ }^{462}$ ЦДІАУ: f. 39, op. 1, spr. 158, k. 125-125v.

463 Ibidem, spr. 42, k. $148 \mathrm{v}$.

${ }^{464}$ Ibidem, k. 74-74v.

${ }^{465}$ Ibidem, k. 197v.

466 BN: sygn. Rps Akc. 12904, k. 3.

${ }^{467}$ Metryka, s. 523: „R[oku] P[ana] 1683 dnia 30 Marca. Panu Bogu w ręce oddał duszę

Pan Grzegorz Milkiewic z Kamieńca, niegdyś dyrektorem i wójtem bywał w Kamieńcu”.

468 ЦДІАУ: f. 39, op. 1, spr. 158, księga sądu ormiańskiego, k. 125-125v.

469 BZNiO: sygn. 1359/II, Akta sądu [...] w Stanisławowie 1681-1689, s. 162-163.

${ }^{470}$ BN: sygn. Rps Akc. 12904, k. 3.

${ }^{471}$ ЦДІАУ: f. 39, op. 1, spr. 158, k. 125-125v.

472 Ibidem, spr. 42, k. 83.

473 Ibidem, spr. 158, k. 125-125v.

${ }^{474}$ Ibidem, spr. 42, k. 83v.

475 BZNiO: sygn. 1732/II, Protocollum actorum consistorii, k. $59 \mathrm{v}$.
} 
281. Jadwiga Seferowiczówna Miłkiewiczowa (Milkiewiczowa) - córka Elżbiety i Sefera Minasowiczów (por. Sefer i Seferowa, „Lehahayer”, 6, s. 57).

282. Marianna Emirowiczówna Miłkiewiczowa (Milkiewiczowa) $(\dagger \text { przed 1689) })^{476}-$ prawdopodobnie 1v. Serhiowiczowa - żona Tumana Serhiowicza $(\dagger$ 1662/1676, przedstawiciela Rady Czterdziestu Mężów - 1651777, właściciela kamienicy na Rynku Ormiańskim, domu i pasiek za miastem ${ }^{478}$ ); żona Axenta Miłkiewicza (zob.).

284. Anna (Febronia) Miłkiewiczówna (Milkiewiczówna) - prawdopodobnie córka Axenta Miłkiewicza (zob.), chrzestna we Lwowie, w 1717 roku $^{479}$.

348. Elżbieta Minasowiczowa - siostra Chumarki Piotrowej († przed 1661, właścicielka domu przy Rynku Ormiańskim, koło placu siostrzeńca (lub bratanka), Mikołaja Pirumowicza ${ }^{480}$, matka Piotrowiczów: Jana i Zachariasza († przed 1651), ciotka dzieci Anny (zob. lista ofiarodawców) i Jakuba Pirumowiczów ${ }^{481}$, żona Sefera Minasowi$\mathrm{cza}^{482}$, była stroną w sprawach sądowych jako wdowa od 1654 roku $^{483}$.

291. Daniel Mitkiewicz - ojciec Kaspra [Danielowicza] (zob.) (1672) ${ }^{484}$; w 1661 roku występował w sądzie w sporze z Asłanem Emirowiczem (zob.) o dług z Zamościa z 1656 lub 1657 roku $^{485}$.

294. Kirkor (Grzegorz) Mitkiewicz Naliwajko - prawdopodobnie brat Krzysztofa Mitkiewicza (Naliwajki) (zob. „Lehahayer”, 6, s. 52), zmarłego około 1658 roku, męża Chatuny (zob.) ${ }^{486}$. Mąż Mitkiewiczowej (zob. „Lehahayer”, 6, s. 53). Kuśnierz, otrzymał 12 talarów (Filibe, 21 sierpnia 1676); posiadacz domu lub placu w Kamieńcu ${ }^{487}$. Zamieszkał w Stanisławowie $(1685)^{488}$.

293. Zofia Mitkiewiczowa - żona Daniela (a nie Krzysztofa, jak błędnie podałam w „Lehahayer", 6), matka Kaspra [Danielowicza] (zob.).

Chatuna Mitkiewiczowa Naliwajkowa (Nalewajkowa) - żona Krzysztofa ( $†$ ok. $1658^{489}$, zob. „Lehahayer”, 6, s. 52), prawdopodobnie tożsama z Mitkiewiczową Naliwajkową (zob. „Lehahayer”, 6, s. 53), określoną błędnie jako żona Kirkora. Możliwe, że Jakub Mikołajewicz (zob.) za nią w 1676 roku w Filibe odebrał pieniądze: ,imie[niem] Ciotek moich Nalewajkowej i Simanonowej podpisuię mpp [...]" (Dokument nr 13).

${ }^{476}$ Ibidem, k. $159 \mathrm{v}$.

477 ЦДІАУ: f. 39, op. 1, spr. 158, k. 72v.

478 Ibidem, k. 133v-134.

479 Metryka, s. 637: „Przewielebny ksiądz Andrzej Pirumowicz ochrzcił córkę P[ana] Piotra Pirumowicza i małżonki Marianny. Dał imię Barbara, a bierzmowane Katarzyna. Był kumem P[an] Mikołaj Sahagowicz, a kumą Panna Anna Axent Milkiewiczówna”.

${ }^{480}$ ЦДІАУ: f. 39, op. 1, spr. 42, k. 142v.

481 Ibidem, k. 187.

482 Ibidem, spr. 158, k. 129v-130.

${ }^{483}$ Ibidem, spr. 41, k. 73v.

${ }^{484}$ Archiwum Narodowe w Krakowie: Archiwum Sanguszków Podhoreckie II, sygn.

Podh II 165, Księga wójtowska z Jazłowca 1648-1669, b. p.

${ }^{485}$ ЦДІАУ: f. 39, op. 1, spr. 42, k. 189v.

${ }^{486}$ Ibidem, k. 90.

487 Ibidem, k. 109.

488 BZNiO: sygn. 1732/II, Protocollum actorum consistorii, k. 24.

489 ЦДІАУ: f. 39, op. 1, spr. 42, k. 90. 
Halszka Mliczkowsczanka - w Filibe w 1676 roku otrzymała pieniądze (Dokument nr 13); możliwe, że tożsama z Halką Mołokówną (zob. „Lehahayer”, 6, s. 53).

Awakum [Muradczyk] - syn Muradczyka $(1681)^{490}$.

Emirhan (Emir, Amira?) [Muradowicz] - syn Murada $(1681)^{491}$.

298. Jan A. (Olbracht) Muradowicz - możliwe, że ten sam („Jan Murat Gamencacji, syn senatora") w Stanisławowie około 1682 roku dał do kościoła ormiańskiego dwa obrazy ${ }^{492}$.

Jezus [Muradowicz] - syn Murada, brat Kadmosa (zob.) $(1681)^{493}$.

Kadmos [Muradowicz] - syn Murada, brat Jisa (zob.) $(1681)^{494}$.

Makar [Muradowicz] - syn Murada $(1681)^{495}$.

Saruhan [Muradowicz] - syn Murada, jego najmitą (pachołkiem) był Iwanes (zob.) $(1681)^{496}$.

Sefer [Muradowicz] - syn Murada $(1681)^{497}$

299. Serhij Muradowicz - pojawił się w sądzie w 1654 roku w związku z dokumentem wydanym przez króla dla rzeźników kamienieckich ${ }^{498}$; był świadkiem spisania przedmiotów kościelnych w Sozopolu w 1675 roku po śmierci wójta Kuryły Miłkiewicza (Dokument nr 3).

Szymon Muradowicz - sprawa sądowa z 1644 roku z jego udziałem była przedstawiana jako precedensowa w sądzie w 1654 roku ${ }^{499}$; możliwe, że ten sam (Simon, syn Simona Murada) był w Kamieńcu w 1681 roku ${ }^{500}$.

Mowses [Mynkowicz] - syn Mynko (1681) ${ }^{501}$.

Mardyk [Myrdyczowicz (?)] Zgórnowski (?) - syn Myrdycza (?) Zgórnowskiego (?) $(1681)^{502}$

Sefer [Nazarowicz] - syn Nazara, był u Porty $(1681)^{503}$.

Sefer [Nazarowicz (?)] - syn Nazara (?) (1681) ${ }^{504}$.

Iczhan [Ondanesowicz, Ohanesowicz (?)] - syn Ondanesa (?) (może Ohanesa?) (1681) ${ }^{505}$.

309. Warteres Orłowski (Orlik) († po 1690, jeśli tożsamy z „Orłowskim dziadem”506) w 1676 roku był w Filibe przedstawicielem Rady Czterdziestu Mężów (Dokument

490 D. Kołodziejczyk, The Ottoman Survey, s. 89.

491 Ibidem.

492 FKiDOP: sygn. 18/226, Inwentarz i księga wydatków, s. 4.

493 D. Kołodziejczyk, The Ottoman Survey, s. 89.

494 Ibidem.

495 Ibidem.

496 Ibidem.

497 Ibidem.

498 ЦДІАУ: f. 39, op. 1, spr. 41, k. 113v.

499 Ibidem, k. 76v.

500 D. Kołodziejczyk, The Ottoman Survey, s. 89.

501 Ibidem.

502 Ibidem, s. 88.

${ }_{503}$ Ibidem.

504 Ibidem, s. 89.

${ }^{505}$ Ibidem, s. 88.

${ }^{506}$ Metryka, s. 508. 
nr 11, nr 12). Prawdopodobnie tożsamy z Wareteresem Orłowiczem, który występuje przed sądem w latach $1652^{507}-1659$.

9. Amira „stary” (Uưhpu huupn $\eta^{508}$ - Amira chart) Owakowicz - w sądzie pojawił się m.in. w $1651^{509} \mathrm{i}$ w 1659 roku $^{510}$. Ojciec (Jana) Takwora Amirowicza ${ }^{511}$ († 2 lipca 1651$)^{512}$, od ok. 1647 roku męża Marty Karakaszówny (córka Torosa Karakasza Iwanisowicza) ${ }^{513}$. Prawdopodobnie też ojciec Awaka Amirowicza (zob.).

28. Owakowiczowa (Awakowiczowa) - w 1676 roku w Filibe w jej imieniu pieniądze odebrał Grzegorz Tumanowicz: „,imie[niem] Panię Owakowiczowey [por. Awakowiczowa, „Lehahayer” 6, s. 20] podpisuię mpp” (Dokument nr 13).

Owanes - ksiądz $(1681)^{514}$.

Chaczadur [Owanesowicz] - syn Owanesa $(1681)^{515}$.

Mikołaj (Mitko) [Owanesowicz] - „Nigoł, syn Jana Gamencacji”, czyli Jana z Kamieńca, ,dał zrobić 1 mur koło kościoła [ormiańskiego w Stanisławowie]” (1682) ${ }^{516}$. Być może tożsamy z Mikołajem Owanesowiczem Kiosą (Kosą), bratem Isaka (Sahaka) i Maksyma, który występował przed sądem w Stanisławowie w latach 1682-1701517. Możliwe też, że mur ufundował Mikołaj Baran Owanesowicz, mieszkaniec Lwowa (zob.).

Bohos (Paweł) Owanesowicz Ruszczuk († 1704/1717) - pochodził z Ruszczuku (dziś: Ruse); możliwe, że tożsamy z mężem Anny Owanesowiczowej Ruszczukowej (zob.) i jako taki mógł być mieszkańcem Kamieńca około 1674 roku; mieszkaniec Stanisławowa, w którym kupił dworek po Teodorze Hoczanie ${ }^{518}$.

345. Anna [Owanesowiczowa Ruszczukowa] (1652-1731) - prawdopodobnie tożsama z Ruszczukową (zob. „Lehahayer”, 6, s. 57); żona Bohosa Owanesowicza Ruszczuka (zob.); w sądzie w Stanisławowie od 1697 roku $^{519}$ ), matka Bohosowiczów: Bogdana (1683-1767) i Jana (ok. 1684-1754), Mariam Manugiewiczowej i Anny Mikołajewiczowej. Zmarła w Stanisławowie ${ }^{520}$.

Zachariasz Owanisowicz (Iwanisowicz) Zadykiewicz - ksiądz, był świadkiem spisania przedmiotów kościelnych w Sozopolu w 1675 roku (Dokument nr 3, nr 5), a następnie w Filibe, w 1676 roku (Dokument nr 11, nr 12, nr 16).

312. Maresia Pałaszówna (Dokument nr 13).

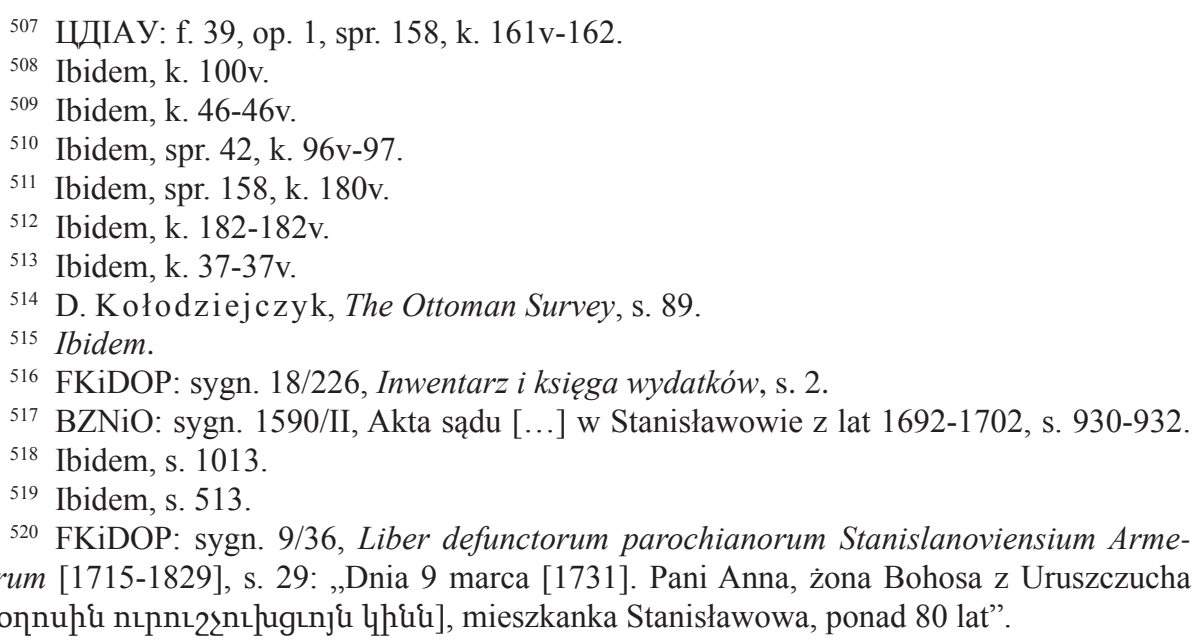


313. Rozalia Pawłowska $(† 7 \text { maja } 1699 \text { we Lwowie })^{521}$ - prawdopodobnie żona Zachariasza (Dokument nr 13).

314. Kirkor (Grzegorz) Pierzadowicz (Pirzada) († po 1686) - obywatel Kamieńca, potem Jazłowca, uwolniony z niewoli tureckiej, świadek w sądzie konsystorskim we Lwowie w 1686 roku $^{522}$.

315. Szymon Pierzadowicz (Pierzad, Piotrowicz) († przed 1685) - syn Pierzady (Piotra) Nuridzianowicza ${ }^{523}$ (Pierzada, spisując w 1651 roku testament, podał do akt ,ppotectorat" króla Jana Kazimierza, w którym mowa jest o przywileju danym Piotrowi Nuridzianowiczowi przez poprzedniego monarchę, Władysława IV ${ }^{524}$ ). Brat Augustyna († przed 1651525). Mąż Anastazji Bogdanowiczówny (zob.), prawdopodobnie szwagier Dominika Bogdanowicza ze Lwowa, ojciec (zob.): Tomasza Pierzadowicza, Anny Mikołajewiczowej Cyntwarowicz ${ }^{526}$ i [Katarzyny?] Pierzadowiczówny Bogdanowej. W księgach sądu ormiańskiego kamienieckiego w latach 1651-1654 pojawia się jako członek Rady Czterdziestu Mężów ${ }^{527}$, potem jako strona w procesie albo świadek; w Sozopolu w 1675 roku jako członek Rady Czterdziestu Mężów (Dokument nr 3).

Tomasz Szymon[owicz] Pierzadowicz (Pirzadowicz) († po 1694) - syn Szymona i Anastazji, mąż Zofii Mikołajewiczówny Cyntwarowicz. Wraz z żoną, siostrą Anną, i szwagrem pozbywali się udziałów w kamienicy Bogdanowiczowskiej we Lwowie na rzecz Dominika Bogdanowicza i jego żony w 1689 roku $^{528}$. W tym samym roku pozywał w Stanisławowie Daniela Mikołajewicza Cyntwarowicza (drugiego szwagra), swojego wspólnika w interesach, że ten naraził go w obozie pod Kamieńcem na niewolę tatarską, z której wykupiono go za 60 talarów lewkowych ${ }^{529}$. Przed sądem stanisławowskim stawał jeszcze w 1694 roku za długi ${ }^{530}$.

316. Anastazja Bogdanowiczówna (Pierzadowa) Pierzadowiczowa († przed 1689) żona Szymona (zob.). Chyba ta sama występuje w 1656 roku jako świadek przed sądem ormiańskim kamienieckim ${ }^{531}$.

318. Grzegorz Pilawski - syn Oskihadki Seferowej († przed 1658), brat Marencji ${ }^{532}$ i Tomasza (zob. „Lehahayer”, 6, s. 55). Otrzymał od Jakuba Potockiego, pisarza polnego koronnego, wieś Kłubowce pod Tyśmienicą jako zastaw za 11 tys. złp. Synowie innego nobilitowanego Ormianina, Mikołaja Hadziewicza, Grzegorz i Piotr, w 1668 roku procesowali się przez Trybunałem Koronnym w Lublinie z kapitanem Grzegorzem Seferowiczem-Pilawskim o wielką sumę w pieniądzach, złocie i srebrze, który

${ }^{521}$ Metryka, s. 528.

${ }^{522}$ BZNiO: sygn. 1732/II, Protocollum actorum consistorii, k. 52v.

${ }_{523}$ ЦДІАУ: f. 39, op. 1, spr. 158, k. 44.

524 Ibidem, k. 44-44v.

525 Ibidem, k. 44v.

526 BZNiO: sygn. 1359/II, Akta sądu [...] w Stanisławowie 1681-1689, s. 421.

${ }^{527}$ ЦДІАУ: f. 39, op. 1, spr. 158, k. 72v, k. 185; spr. 41, k. 53v, k. 113.

${ }_{528}$ BZNiO: sygn. 1359/II, Akta sądu [...] w Stanisławowie 1681-1689, s. 421-422.

529 Ibidem, s. 441.

530 BZNiO: sygn. 1590, s. 159, 200, 265.

531 ЦДІАУ: f. 39, op. 1, spr. 41, k. 227.

${ }^{532}$ Ibidem, spr. 42, k. $72 \mathrm{v}$. 
tenże pobrał od ich ojca i miał zawieść do Kamieńca, ale tego nie dokonał (wyrok 10 lipca). Był potem starostą knyszyńskim $(1686)^{533}$. On, albo inny Pilawski, był winien 300 talarów lewkowych Ulchatunce Damenesztowej Bogdanowiczowej (zob.) $(1696)^{534}$.

321. Krzysztof [Jakubowicz] Pirumowicz († 1676/1688) - młodszy syn ${ }^{535}$ Anny Kasprówny ${ }^{536}$ i Jakuba Pirumowiczów, brat: biskupa Grzegorza, Zofii Emirowiczowej (zob.), Katarzyny Krzysztofowiczowej ${ }^{537}$, Mikołaja ${ }^{538}$, Gertrudy ${ }^{539}$ (zob.), Marty (zob.), Zuzanny Nurinowiczowej ${ }^{540}$. Mąż Marencji Chodzikówny ${ }^{541}$ (zob.). Kupiec, w 1652 roku w Kamieńcu nie miał żadnej nieruchomości, mieszkał w kamienicy Goxowskiej ${ }^{542}$, a w 1655 roku, wraz z żoną, posiadał kamienicę Łukaszowską przy Rynku Ormiańskim między domami potomków Harburasza a potomków Jurka Kasprowicza $^{543}$, naprzeciw Ratusza Ormiańskiego ${ }^{544}$. W Filibe był przedstawicielem Rady Czterdziestu Mężów (Dokument nr 7 i nr 16).

325. Usunięta z listy: Anna Kasprówna [Pirumowiczowa, Piramowiczowa] $(\dagger 1651$ podczas zarazy) ${ }^{545}$.

323. Marencja Chodzikówna Pirumowiczowa († po 1688) ${ }^{546}$ - córka Chodzika Hołubowicza (zob.), żona Krzysztofa Pirumowicza (zob.), występowała wspólnie z mężem przed sądem w latach 1655 i $1656^{547}$.

Zuzanna Awedykowiczówna Pirumowiczowa ( $†$ po $1680^{548}$ ) - córka Andrzeja Awedykowicza ze Lwowa, żona Mikołaja Pirumowicza († ok. 1651), mieli pięcioro dzieci ${ }^{549}$, właściciele gruntu przy Rynku Ormiańskim między kamienicą Kirkora Tatułowicza (zob.) a domem Chumarki ${ }^{550}$. Zakładnikom lwowskim w Kamieńcu pożyczyła 200 talarów za pośrednictwem Zachariasza Asłana Emirowicza (zob.) ${ }^{551}$.

326. Gertruda Pirumowiczówna († po 1674) - córka Anny Kasprówny i Jakuba Pirumowiczów, siostra: biskupa Grzegorza, Krzysztofa (zob.), Zofii Emirowiczowej (zob.),

${ }_{533}$ S. Barącz, Żywoty, s. 285; S. Barącz, Pamiętnik dziejów polskich, Lwów 1855 , s. 321; K. Niesiecki, Herbarz polski, wyd. J. N. Bobrowicz, 7, Lipsk 1841, s. 305.

${ }^{534}$ BZNiO: sygn. 1359/II, Akta sądu [...] w Stanisławowie 1681-1689, s. 435.

${ }^{535}$ ЦДІАУ: f. 39, op. 1, spr. 158, k. 48v.

536 Ibidem, k. 53.

537 Ibidem, k. 98.

538 Ibidem, k. 107.

539 Ibidem, k. 90.

${ }^{540}$ Ibidem, k. $188 \mathrm{v}$.

${ }^{541}$ Ibidem, spr. 41, k. 118v, 226.

${ }^{542}$ Ibidem, spr. 158, k. 112.

${ }^{543}$ Ibidem, spr. 41, k. 226.

${ }^{544}$ Ibidem, k. 118v.

545 Ibidem, spr. 158, k. 59, 98.

546 BZNiO: sygn. 1732/II, Protocollum actorum consistorii, k. 92.

${ }^{547}$ ЦДІАУ: f. 39, op. 1, spr. 41, k. 118v, 226.

548 ЦДІАУЛ: f. 52, op. 2, spr. 531, s. 1540, 1569.

549 ЦДІАУ: f. 39, op. 1, spr. 158, k. 107.

550 Ibidem, spr. 42, k. 142v.

551 Ibidem, spr. 531, s. 1540, 1569. 
Katarzyny Krzysztofowiczowej ${ }^{552}$, Mikołaja ${ }^{553}$, Marty (zob.), Zuzanny Nurinowiczowej. Niedoszła żona Jana Bobrykiewicza (zob.), który - jak skarżyli się jej krewni - ,żarty jakieś raczej stroi z domu naszego [...], dla czegoby raz dawszy pannie słowo, przez tak długi czas i razu wedla zwyczaju i trybu młodzieńskiego w domu panny niepostoi” $(1652)^{554}$.

258. Marta Pirumowiczówna († po 1676) - córka Anny i Jakuba Pirumowiczów, siostra: biskupa Grzegorza, Krzysztofa (zob.), Zofii Emirowiczowej (zob.), Katarzyny Krzysztofowiczowej ${ }^{555}$, Mikołaja ${ }^{556}$, Gertrudy ${ }^{557}$ (zob.), Zuzanny Nurinowiczowej ${ }^{558}$. W sprawie testamentu ojca występowała jako świadek $(1652)^{559}$. W sprawie przysługujących jej 2000 zł określana jako „nabożna”, być może więc mniszka $1658^{560}$.

328. Augustyn (Axent) Piszczatyński - w 1676 roku w Filibe występował jako przedstawiciel Rady Czterdziestu Mężów (Dokument nr 11, nr 12).

330. Aschapet Putretowiczowa (Putretowa) - możliwe, że tożsama z Putretową, wdową po Kirkorze Putretowiczu († przed 1652); jej siostrzeńcem był Awak (Owak?) Seferczyk Kirkorowicz (1652) ${ }^{561}$ (zob. Jan Kirkorowicz).

Aswadu[r] [Pytryn (?)] - syn Pytryna, brat Keworyna $(1681)^{562}$.

Keworyn (?) [Pytryn (?)] - syn Pytryna, brat Aswadura (1681) ${ }^{563}$.

Anna Talczykówna Radecka - córka Krzysztofa Talczyka, w 1702 roku we Lwowie wyszła za mąż za Stanisława Radeckiego ${ }^{564}$.

Deodat (Bogdan) Romaszkiewicz ( $†$ 1710) - możliwe, że syn Zachariasza Romaszkiewicza (zob.), ożenił się w 1709 roku z Marianną Manugiewiczówną, z którą miał syna, Zachariasza Romaszkiewicza ${ }^{565}$.

334. Grzegorz (Kirkor, Jerzy) Romaszkiewicz († po 1708) - pochodził z rodziny „,szlachetnego" (nobilis) Jana Romaszkiewicza († przed 1658, męża Katarzyny Kieworowiczówny), tożsamego z tłumaczem i agentem dyplomatycznym polskim na Wschodzie, nazywanym czasem w literaturze historycznym imieniem Piotr $^{566}$. Brat Jana (zob.). W 1675 i 1676 roku w Filibe - delegat do Adrianopola (Dokument

${ }^{552}$ Ibidem, spr. 158, k. 98.

553 Ibidem, k. 107.

${ }^{554}$ Ibidem, k. $117 \mathrm{v}$.

555 Ibidem, k. 98.

556 Ibidem, k. 107.

${ }^{557}$ Ibidem, k. 90.

558 Ibidem, k. 188v.

559 Ibidem, k. 98.

560 Ibidem, spr. 42, k. 66.

${ }^{561}$ Ibidem, spr. 158, k. 133-133v.

${ }^{562}$ D. Kołodziejczyk, The Ottoman Survey, s. 89.

563 Ibidem.

564 Metryka, s. 512.

565 B. Czart.: sygn. 3543 IV, k. 59.

566 M. Nagielski, Romaszkiewicz (Romaszkiewic, Romaszkowicz) Jan bądź Piotr, w: Polski słownik biograficzny, 31, Wrocław-Warszawa-Kraków 1988, s. 620-621; M. Tomaszews ki, Działalność dyplomatyczna i agenturalna Jana bądz Piotra Romaszkiewicza w latach 1648-1655, „Przegląd Orientalistyczny” 2014, 3/4, s. 149-156. 
nr 12), dwukrotny delegat do Porty (Dokument nr 7, nr 14, nr 15), przedstawiciel Rady Czterdziestu Mężów (Dokument nr 11, nr 16).

335. Jan Romaszkiewicz - brat Grzegorza (zob.), w 1676 roku występowała w Filibe jako przedstawiciel Rady Czterdziestu Mężów (Dokument nr 16).

Zachariasz Romaszkiewicz († po 1726) - brat lub krewny Grzegorza (zob.) i Jana (zob.), chrześniak Ulchatunki Bogdanowiczowej Daminesztowej (zob.), którą opiekował się w latach 1683-1696 i dziedziczył po niej ${ }^{567}$, mąż Egine Muradowiczówny (zob. Lehahayer, 6, s. 56), ojciec czterech córek (zob.): Hanusi Mikołajewiczowej (1686 4 października 1764), Zofii Bogdanowiczowej (1691 - 19 października 1732), Kasu Sahagowiczowej (1695 - 5 lutego 1732), Mariam Kirkorowiczowej, i prawdopodobnie Deodata Romaszkiewicza († 1710). Osiadł w Stanisławowie. W 1678 roku podpisał się pod „ustawą" cechu safianników ${ }^{568}$, i tam w 1682 roku przekazał dary dla kościoła ormiańskiego ${ }^{569}$, a od 1685 do $1705^{570}$ roku sprawował funkcje: marszałka Rady Czterdziestu Mężów, pisarza, rajcy, wójta. Pisarz komory (celnej) śniatyńskiej (1697) ${ }^{571}$.

Kirkor (Grzegorz) Sahakowicz (Sahagowicz) - możliwe, że syn Kirkora Kirkorszowicza († przed 1652), brat: Sahaka ${ }^{572}$ († ok. 1651, miał córkę z Rusinką Hanną Iwanowną $\left.{ }^{573}\right)$, Iwanisa ${ }^{574}$ i Róży Jakubowiczowej ${ }^{575}$. W sądzie pojawił się od 1652 roku. W 1681 roku w Stanisławowie mieszkał safiannik o tym imieniu i nazwisku $^{576}$. W 1687, 1688 i 1693 roku w Złoczowie Grzegorz i Gertruda „Sachagowicz" chrzcili swoich synów: Stefana Łukasza (chrzestnymi byli Bazyli i Zofia Bartoszewiczowie), Łukasza i Michała ${ }^{577}$. W 1696 roku przed sądem ormiańskim stanisławowskim pojawił się Sahakowicz jako kupiec złoczowski ${ }^{578}$.

250. Mikołaj Sahagowicz Mankulec (Mankowicz, orm. Uuuরpo - Mamko) - żonaty z Martą (1652), ojciec Waleriana Mankulczyka (zob. „Lehahayer”, 6, s. 48) i Rozalii Łukaszewiczowej (zob.). W sądzie pojawiał się w latach 1651 i $1652^{579}$.

Donagan [Saruhanowicz] - syn Saruhana, podróżował do Wank (albo Wan) $(1681)^{580}$. 350. Bogdan Seferowicz - prawdopodobnie ten sam, który występuje z żoną w 1655 roku ${ }^{581}$, krawiec $\left(1652-1660^{582}\right)$.

567 BZNiO: sygn. 1359/II, Akta sądu [...] w Stanisławowie 1681-1689, s. 434-436.

568 S. Barącz, Pamiątki miasta Stanisławowa, Lwów 1858, s. 39.

569 FKiDOP: sygn. 18/226, Inwentarz i księga, b. n. s.

570 ЛННБУ: sygn. f. 5, op. 1, spr. 1360/III Księga Akt Orm. No 3ti zaczęto 1703ciego Roku kaczy się 1709, s. 270.

${ }^{571}$ BZNiO: sygn. 1590/II, Akta sądu [...] w Stanisławowie z lat 1692-1702, s. 439.

572 ЦДІАУ: f. 39, op. 1, spr. 158, k. 90v-91.

573 Ibidem, k. 52v.

574 Ibidem, spr. 42, k. 217v.

575 Ibidem, spr. 158, k. 52v.

${ }_{576}$ BZNiO: sygn. 1359/II, Akta sądu [...] w Stanisławowie 1681-1689, s. 19-20.

577 AGAD: sygn. 456/1, Liber metricarum. Ecclesia Armena Zloczoviensis, s. 1a, 2, 6.

578 BZNiO: sygn. 1590/II, Akta sądu [...] w Stanisławowie z lat 1692-1702, s. 412.

579 ЦДІАУ: f. 39, op. 1, spr. 158, k. 101v-102.

${ }^{580}$ D. Kołodziejczyk, The Ottoman Survey, s. 88.

581 А. Н. Гаркавец, Кыпчакское письменное наследие, s. 947.

582 ЦДІАУ: f. 39, op. 1, spr. 42, k. 168. 
351. Jan Mielkon[owicz] (Melkon[owicz]) Seferowicz - możliwe, że tożsamy z Iwaszkiem Seferowiczem, który był w 1675 roku w Sozopolu przy rozliczaniu delegacji do Adrianopola (Dokument nr 6).

Kadmos [Seferowicz] - syn Sefera $(1681)^{583}$.

Krzysztof Seferowicz - brat Zachariasza (zob.) (1658) $)^{584}$, prawdopodobnie ten sam, który w Sozopolu w 1675 roku określany mianem przedstawiciela Rady Czterdziestu Mężów (Dokument nr 3).

352. Krzysztof Seferowicz - w 1723 roku ożenił się w Stanisławowie z Anną, córką Bogdana Osoby z Nadwórny ${ }^{585}$.

353. Murad Seferowicz († po $1690^{586}$ ) - syn Sefera Elczy (?) († przed 1663) ${ }^{587}$; mąż Rozalii $^{588}$ (zob.), przedstawiciel Rady Czterdziestu Mężów (1651 $1^{589}$ i później), przysięgły od $1654^{590}$, erespochan (1658, orm.: puid unıpuun tıpłu - pan Murad jeres. $)^{591}$, w 1662 roku był zastępcą wójta w sprawie o zabicie Augustyna Tatułowicza ${ }^{592}$, w Sozopolu w 1675 roku: jeden z czterech przysięgłych, którzy odpowiedzialni byli za spisanie przedmiotów kościelnych po śmierci wójta Kuryły Miłkiewicza (Dokument nr 1, nr 3), ekonom pieniędzy kościelnych (Dokument nr 4), „oficjalista” (Dokument nr 5, nr 6, nr 7), w Filibe w 1676 roku - „starszy radny” (Dokument nr 16).

355. Zachariasz Seferowicz - brat Krzysztofa ${ }^{593}$ (zob.), od 1656 roku drugi mąż Heleny 1v. Krzysztofowiczowej (zob.). Ekonom (1662) (594 $^{59}$ W Sozopolu był świadkiem spisania inwentarza rzeczy kościelnych (Dokument nr 1), określany mianem przedstawiciela Rady Czterdziestu Mężów (Dokument nr 3), „uproszony director” (Dokument nr 5), „regenta” Rady Czterdziestu Mężów (Dokument nr 6); w Filibe - oficjalista (Dokument $\mathrm{nr} 7, \mathrm{nr} 8$ ).

Seferowiczowa - żona Krzysztofa, otrzymała pieniądze w Filibe w 1676 roku (Dokument nr 13).

Helena Owakowiczówna 1v. Krzysztofowiczowa, 2v. Seferowiczowa - wnuczka Caryka Beznosego Krzysztofowicza ${ }^{595}$, córka Anny Carykówny i Owaka Kirkorowicza, siostra: Krzysztofa Owakowicza, Grzybowskiej (zob.), Róży Krzysztofowiczowej Egzemperowej (zob.). Jej pierwszym mężem był Szymon Beznosy Krzysztofowicz († we wrześniu $1654^{596}$ ), drugim - od ok. 1656 roku - Zachariasz Seferowicz (zob.).

392. Rozalia Seferowiczowa - tożsama z Rozalią Tatułowiczówną (zob. „Lehahayer”, 6, s. 62), córka Tatuła Kirkorowicza († przed 1652), siostra: Augustyna $(\dagger 1658-$

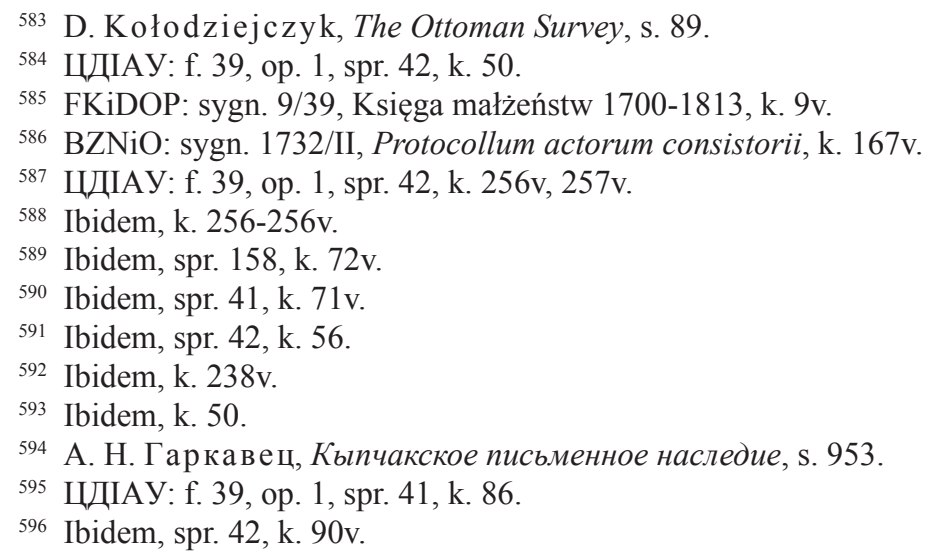


zabity przez opryszków), ks. Mikołaja (kaznodziei w Eczmiadzynie) ${ }^{597}$, Warteresa,

Kirkora (zob.), prawdopodobnie też Krzysztofa; żona Murada Seferowicza (zob.) ${ }^{598}$. Agop [Sarkisowicz] - syn Sarkisa (1681) $)^{599}$.

Kadmos [Sarkisowicz] - syn Sarkisa, był w Tyflisie $(1681)^{600}$.

Sadyk [Sarkisowicz] - syn Sarkisa $(1681)^{601}$.

Szymon Serhiowicz - przysięgły gminy ormiańskiej w Kamieńcu Podolskim w 1666 roku $^{602}$.

339. Stefan Serhiowicz Roszka († 28 marca 1670) $)^{603}$ - mąż Anny Zarugiewiczówny (zob.), zięć Caryka Maxymowicza (zob. Caryk Axentowicz) ${ }^{604}$ ojciec Stefanowiczów Roszków (zob.): Bogdana, Krzysztofa i ks. Stefana; występował w księgach sądowych, w 1651 roku był faktorem Krzysztofa Bogdanowicza Dameneszta ${ }^{605}$.

342. Grzegorz (Kirkor) Serhiowicz Rusin (Rusinowicz) - brat Anny Serhiowiczówny (zob.), w 1675 roku w Sozopolu poświadczał powierzenie części rzeczy kościelnych (Dokument nr 5), w 1676 roku w Filibe był przedstawicielem (Rady Czterdziestu Mężów?) przy delegowaniu do Porty (Dokument nr 7), był delegatem do Porty, by spieniężyć rzeczy na odnowienie kościoła w Filibe (Dokument nr 10), odbierał pieniądze za siebie, siostrzeńców i siostrzenice: ,imieniem siostry moię Anny sierot podpisałem się" (Dokument nr 13).

344. Iwaszko Serhiowicz Rusinowicz - w 1676 roku w Filibe: był świadkiem rozliczania delegacji z Adrianopola (Dokument nr 11) i jako przedstawiciel Rady Czterdziestu Mężów - z Porty (Dokument nr 12); odbierał pieniądze za siebie i za Carkową: „,imieniem Carkowey [zob. Carkowa - „Lehahayer”, 6, s. 31]” (Dokument nr 13); rozliczał się po pójściu do „sędziaka” (Dokument nr 15).

Justyna Kirkorówna Serhiowiczowa - córka Grzegorza Szymonowicza Mamoczki $\left(\dagger\right.$ przed $\left.1656^{606}\right)$, siostra: Szymona Kirkorowicza $(\dagger 1656)$ i Marty Carykowej ${ }^{607}$ (możliwe, że żony Szymona Krzysztofowicza Beznosego); żona Iwaszki Serhiowicza (zob.).

340. Anna Zarugiewiczówna Serhiowiczowa Roszka - córka Dzaruga Axentowicza (zob.), żona Stefana Serhiowicza Roszki (zob.), pochowana w Stanisławowie obok syna, Krzysztofa ${ }^{608}$.

361. Serhiowiczówna (Serhiówna, Serhyjówna) Niedzwiedzianka - w 1676 roku w Filibe otrzymała pieniądze (Dokument nr 13).

597 Ibidem, k. 256-256v.

598 Ibidem.

599 D. Kołodziejczyk, The Ottoman Survey, s. 89.

600 Ibidem, s. 88.

${ }^{601}$ Ibidem, s. 89.

${ }^{602}$ S. Krzyżanowski, Pamiątki polskie, s. 41.

${ }^{603}$ S. Roszka, Chronologia, czyli roczniki kościelne, seria: Pomniki dziejowe Ormian polskich, w przygotowaniu.

${ }^{604}$ ЦДІАУ: f. 39, op. 1, spr. 41, k. 193-193v.

${ }^{605}$ Ibidem, spr. 158, k. 41-41v.

${ }^{606}$ ЦДІАУ: f. 39, op. 1, spr. 41, k. 174v.

607 Ibidem, k. 193-193v.

${ }^{608}$ FKiDOP: sygn. 9/36, Liber defunctorum parochianorum Stanislanoviensium Armenorum [1715-1829], s. 37. 
343. Anna Serhiowiczówna (Serhiówna) Rusinkówna - siostra Grzegorza Serhiowicza Rusina (zob.), w 1676 roku była z dziećmi w Filibe i za nią pieniądze odebrał brat, Grzegorz (Dokument nr 13).

Grzegorz Michał [Serkizowicz] (ur. 9 listopada 1687 we Lwowie) - syn Serkiza Mysyrowicza $^{609}$ (zob. „Lehahayer”, 6, s. 54).

Abryk (?) [Serwan (?)] - syn Serwana (?) (1681) ${ }^{610}$.

Simawonowa (Szymawonowa) - w jej imieniu Jakub Mikołajewicz (zob.) odebrał pieniądze w Filibe w 1676 roku (Dokument nr 13). Możliwe, że tożsama z Lustiginą Szymawonową, matką Wartana Szymawonowicza $(1660)^{611}$.

364. Skiendrowa (Skęderowa) - możliwe, że tożsama ze Skienderową, wdową, która z zięciem mieszkała w 1672 roku w Jazłowcu ${ }^{612}$.

Jakub [Somonowicz Sziwaski] - syn Somona (Salomona?) z Sivas, ojciec Lewonostaryka [Jakubowicza] (zob.) $(1681)^{613}$.

365. Sosnicha (Sośnicha) - w 1675 roku w Sozopolu dała zastaw (Dokument nr 4); jej zięć, Abraham, miał nieruchomość w Stanisławowie koło domu i gruntu Krzysztofa Dryngacza Krzysztofowicza (zob.) ${ }^{614}$.

367. Deodat (Aswadur, Bogdan) Stefanowicz Roszka (ok. 1654 - 25 lub 28 lipca $1729^{615}$ ) - najstarszy syn Anny Zarugiewiczówny i Stefana Serhiowicza Roszków (zob.). Z matką i braćmi dotarł przez Węgry i Tyśmienicę do Stanisławowa (1686), gdzie kupił dom (1695) i się osiedlił. Mąż Edylii (zob.), z którą miał dzieci, urodzone po ucieczce rodziny z Kamieńca, po 1672 roku, używających nazwiska Roszko Bogdanowicz: Zaruga (1683 - 12 lipca 1728), Krzysztofa (11 maja $1686^{616}$ - 9 lipca 1767), Stefana (ok. 1689 - 17 października 1753), Gertrudę Kirkorowiczową (ok. 1697 - 5 października 1730), Bernarda (4 listopada 1703 - przed 1744), Dawida (1705 - 14 września 1754), Lazara († 6 października 1752), Rypsymę Stefanowiczową, Syrmę Teodorowiczową, Annę Łukaszewiczową i Sarkisa. Gdy w 1705 roku Rosjanie plądrowali Pokucie i grozili zajęciem Stanisławowa (co uczynili w 1707 roku), rodzina uciekła najpierw do Śniatyna, gdzie urodził się syn, Dawid, a potem - do Kamieńca na kilka lat (tu w 1708 odbyły się zaręczyny jego córki, Anny), po czym wróciła na stałe do Stanisławowa, gdzie od 1716 do 1725 roku Deodat był rajcą. Po śmierci żony, w 1719 roku, ufundował w kościele ormiańskim kaplicę Matki Bożej Kamienieckiej ${ }^{617}$. Z drugą żoną, Chatuną (1692-1782), miał syna Jakuba Józefa (ur. 1722). Zmarł w 1729 roku, o czym pisał jego brat, ks. Stefan:

Dnia 25 lipca. Chwalony i przeze mnie serdecznie lubiany mój starszy brat pan Aswadur z [rodu] Stefanowiczów-Roszka, aga ze Stanisławowa

${ }^{609}$ Metryka, s. 497.

610 D. Kołodziejczyk, The Ottoman Survey, s. 89.

${ }^{611}$ ЦДІАУ: f. 39, op. 1, spr. 42 k. 152v.

${ }^{612}$ LNNBU: sygn. f. 5, op. 1, spr. 1485, akta sądowe Ormian w Jazłowcu (1669-1672), k. $86 \mathrm{v}$.

613 D. Kołodziejczyk, The Ottoman Survey, s. 87.

614 ЛННБУ: sygn. f. 5, op. 1, spr. 1360/III, s. 21.

${ }^{615}$ FKiDOP: sygn. 9/36, Liber defunctorum, s. 27.

${ }^{616}$ S. Roszka, Chronologia.

${ }^{617}$ FKiDOP: sygn. 18/226, Inwentarz i księga wydatków, s. 29. 
i dyrektor, człowiek wielkiej zgody, cnotliwy, modląc się oddawał cześć Panu Bogu, lubiący biednych, zasługujący na wszelki szacunek, 75 lat. Przyjął ostatnią Komunię we wspólnocie Świętej Matki Kościoła, oddał swoją duszę Bogu z niebywałą cierpliwością znosząc straszne bóle. Zostawił wiele ofiar kościołowi i [środków na] odprawienie mszy, ciało zaś zostało pochowane 28 [dnia] tego miesiąca w kaplicy przed ołtarzem świętego Kajetana. Wielokrotnie był spowiadany i wielokrotnie przyjmował Komunię, przedśmiertną Komunię Świętą i ostatnie namaszczenie otrzymał (w czasie mojego pobytu w Madżarstanie [tj. na Węgrzech]) $\mathrm{z}$ rąk wielce czcigodnego penitencjariusza der Jakoba Warteresowicza. S. S. Roszka, oficjał stanisł[awowski] ${ }^{618}$.

368. Krzysztof (Chaczyk) Stefanowicz Roszka (1661 - 6 października 1738) - syn Anny Zarugiewiczówny i Stefana Serhiowicza Roszków (zob.). Z żoną, Meliką (ok. 1672 26 lipca 1745), miał córkę, Annę (ok. 1700 - 5 marca 1795), i trzech synów: Grzegorza (22 stycznia 1704 - 5 kwietnia 1758), Stefana (22 stycznia 1704 - 24 marca 1754) i Torosa (ur. 8 marca 1710). Razem z rodziną był w Kamieńcu w 1710 roku, gdzie jego brat, ks. Stefan, ochrzcił jego najmłodszego syna, Torosa. W stanisławowskiej księdze zgonów ks. Roszka zapisał:

Roku Pańskiego 17386 października. Pan aga Chaczyk Stefanowicz Roszka - mąż troszczący się o biednych, ceniący dobro i cnotliwy, 77 lat. Przyjął ostatnią Komunię we wspólnocie Świętej Matki Kościoła, oddał duszę Bogu i został pochowany na tutejszym cmentarzu w kierunku północnym obok własnej i mojej matki. Przyjął wszystkie sakramenty Kościoła z rąk wielce czcigodnego der Jakoba Manugiewicza - mojego wikariusza $^{619}$.

371. Grzegorz (Kirkor) Stefanowicz (Stepanowicz) Wilczek - możliwe, że tożsamy z Grzegorzem Stefanowiczem, złotnikiem $(1655)^{620}$. W 1661 roku pojawił się w sądzie jako świadek ${ }^{621}$. W Filibe w 1676 roku był przedstawicielem Rady Czterdziestu Mężów (Dokument nr 11, nr 12); pobrał pieniądze ,,imieniem siostr zony” (Dokument nr 13). Możliwe, że tożsamy z Kirikorem, synem Istefana, który w 1681 roku przebywał w Temeszwar (Timisoara) ${ }^{622}$.

372. Owanko Stefanowicz Wilczek († po 1690) - krawiec, w sądzie pojawiał się od 1654 roku $^{623}$. W 1675 roku w Sozopolu przedstawiciel Rady Czterdziestu Mężów (Dokument nr 3). W 1676 roku w Filibe przedstawiciel Rady Czterdziestu Mężów (Dokument nr 11, nr 12); wziął pieniądze w imieniu Róży Hodowańcówny (zob.) i popadii (żony ks. Michała Dermichałowicza?) (Dokument nr 13).

${ }^{618}$ FKiDOP: sygn. 9/36, Liber defunctorum parochianorum Stanislanoviensium Armenorum [1715-1829], s. 27.

619 Ibidem, s. 37.

${ }^{620}$ ЦДІАУ: f. 39, op. 1, spr. 41, k. 144-144v.

${ }^{621}$ Ibidem, spr. 42, k. 217v.

${ }^{622}$ D. Kołodziejczyk, The Ottoman Survey, s. 89.

623 ЦДІАУ: f. 39, op. 1, spr. 41, k. 91v-92. 
Edylia Stefanowiczowa Roszkowa $\left(1660\right.$ - † 21 września 1719) - siostra Kirkora ${ }^{624}$, pierwsza żona Deodata (zob.), zmarła na dżumę:

21 września. Pani Edił [Edylia], żona agi [rajcy] pana Aswadura z [rodu] Stefana [Uuntıhuiłtıg] z Kamieńca, bardzo pobożna. Miłosiernie odwiedzając wyżej wymienioną Warte Janową [Tumanowiczową] i rozmawiając z nią, zgodnie z istniejącą opinią, zaraziła się od niej. Wyspowiadawszy się w czasie silnej gorączki, po 10 dniach odeszła w Chrystusie. Przed śmiercią zostawiła bractwu Świętego Grzegorza Oświeciciela tysiąc złotych na odprawiania po jej śmierci mszy w każdy wtorek przy ołtarzu głównym w Stanisławowie. Odeszła mając 59 lat ${ }^{625}$.

Owankowa [Stefanowiczowa Wilczkowa] - odebrała pieniądze w 1676 roku w Filibe (Dokument nr 13).

[Stefanowiczowej Wilczkowej siostra] - szwagierka Grzegorza Stefanowicza Wilczka (zob.), który w jej imieniu pobrał pieniądze w Filibe w 1676 roku (Dokument nr 13).

[Stefanowiczowej Wilczkowej siostra] - druga szwagierka Grzegorza, który w jej imieniu pobrał pieniądze w Filibe w 1676 roku (Dokument nr 13).

380. Symonówny (Simonówne) - „rzeźniczanki” (Dokument nr 13).

Allahwirdi [Szahanszah] - syn Szahanszaha (1681) ${ }^{626}$.

Szahin - służący (pomocnik) piekarza Manuga [Matiaszewicza] (zob.) $(1681)^{627}$.

Róża Szapowałowa - odebrała pieniądze w 1676 roku w Filibe (Dokument nr 13) (por. Warte (Róża) Mamuchczy, „Lehahayer”, 6, s. 48).

Baltazar Szymonowicz - syn (zob.) Szymona i Zofii Balewiczów, przyjęty do prawa lwowskiego w 1694 roku ${ }^{628}$.

382. Jakub Szymonowicz - rzeźnik, pojawiał się w księgach sądu ormiańskiego w Kamieńcu już w 1654 roku $^{629}$ i później.

Zachariasz [Szymonowicz] Bekiesz (ur. 12 marca 1682 we Lwowie) - syn Szymona Bogdanowicza Bekiesza ${ }^{630}$ (zob.); w 1723 roku ożenił się w Stanisławowie z Mariam, córką Stefana Bedrosowicza ${ }^{631}$.

190. $=$ 105. = 386. Mikołaj (Nigoł, Mitko) Szymonowicz (Dzerykowicz) Karakasz (Czoban) († przed 1696), prawdopodobnie tożsamy z Mikołajami: Karakaszem, Czobanem, Szymonowiczem - syn Dzeryga, erespochana (1638) ${ }^{632}$, mąż Marianny, ojciec Karakaszów Mikołajewiczów (zob.): Jana, Szymona, Bogdana i Anny Bogdanowiczowej (Stanisławów, 1696) ${ }^{633}$. W sądzie kamienieckim notowany był

${ }^{624}$ B. Czart.: sygn. 3543 IV, k. 105.

${ }^{625}$ FKiDOP: sygn. 9/36, Liber defunctorum parochianorum Stanislanoviensium Armenorum [1715-1829], s. 13.

${ }^{626}$ D. Kołodziejczyk, The Ottoman Survey, s. 89.

627 Ibidem, s. 90.

628 Album civium Leopoliensium, 1, s. 343.

629 ЦДІАУ: f. 39, op. 1, spr. 41, k. 111.

${ }^{630}$ Metryka, s. 484.

631 B. Czart.: sygn. 3543 IV, k. 112 v.

632 А. Н. Гаркавец, Кыпчакское письменное наследие, s. 931.

633 B. Czart.: sygn. 3543 IV, k. 17. 
w 1652 roku ${ }^{634}$; w Sozopolu - w 1675 roku (Dokument nr 3). W 1676 roku w Filibe występował trzykrotnie (Dokument nr 11 - razem z bratem, Grzegorzem; nr 13) i jako przedstawiciel Rady Czterdziestu Mężów (Dokument nr 16). Potem pojawił się w Stanisławowie w sądzie $(1683)^{635}$. Osiedlił się z rodziną w Stanisławowie.

338. Chaczko (Krzysztof) Kirkor [Szymonowicz] Rospopczik - ksiądz, syn Zofii Kirkorówny (1652) ${ }^{636}$ i Szymona Stefanowicza Rospopczika († 1655), brata stryjecznego Szymona Pierzadowicza (zob.).

Marianna Szymonowiczowa Karakaszowa († po 1696) - żona Mikołaja (zob.) ${ }^{637}$.

389. Krzysztof (Krzyśko) Talczyk - ojciec Anny Radeckiej (zob.). W 1676 roku w Filibe był przedstawicielem Rady Czterdziestu Mężów (Dokument nr 12).

K[risto]s [Tanas] - syna Tanasa, przebywał w 1681 roku w Wan ${ }^{638}$.

390. Kirkor Tatułowicz (Tatułczyk) († przed 1695 ${ }^{639}$ ) - syn Tatuła Kirkorowicza, brat: Augustyna, ks. Mikołaja, Warteresa ${ }^{640}$, Rozalii Seferowiczowej (zob.), prawdopodobnie Krzysztofa; przedstawiciel Rady Czterdziestu Mężów (1652) ${ }^{641}$; cechmistrz kramarski $(1654,1656)^{642}$. Po ojcu miał kamienicę w Rynku Ormiańskim blisko Ratusza Ormiańskiego, między kamienicą Bogdana Hankiewicza a pustym gruntem Mikołaja Jakuba Pirumowicza (1660) $)^{643}$.

396. Donowak Theodorowicz (Teodorowicz) - możliwe, że pochodził z Botoszan, skąd trafił do Kamieńca ${ }^{644}$; w sprawach sądowych notowany był od 1653 roku ${ }^{645}$; w 1675 roku przebywał w Sozopolu, także jako przedstawiciel Rady Czterdziestu Mężów (Dokument nr 3, nr 5, nr 6, nr 7), i w Filibe, w 1675 i 1676 roku jako delegat do Adrianopola i do Konstantynopola (Dokument nr 10, nr 11, nr 12), i w 1677 roku (Dokument nr 19).

Iwas (Jan) [Todorowicz] - syn Todorosa $(1681)^{646}$.

Theodorowicz - syn Jakuba z Kamieńca, około 1682 roku „dał zrobić 1 mur koło koscioła" ormiańskiego w Stanisławowie ${ }^{647}$.

Bogdan Torosowicz (1679-1739) - syn Torosa Bogdanowicza (zob.) i Kirkorówny, dwukrotnie żonaty; pierwsza żona - Zofia Kirkorówna (1682-1722), córka Kirkora z Persji (adżama) i Katarzyny (1648-1719) ${ }^{648}$, możliwe, że siostra (bratanica?) Ohana Kirkorowicza ( $†$ ok. 1680; za pozostawione przez niego m.in. 454 talary lewkowe

${ }^{634}$ ЦДІАУ: f. 39, op. 1, spr. 158, k. 125.

635 BZNiO: sygn. 1359/II, Akta sądu [...] w Stanisławowie 1681-1689, s. 189.

${ }^{636}$ ЦДІАУ: f. 39, op. 1, spr. 158, k. 123.

637 B. Czart.: sygn. 3543 IV, Akta zaręczynowe, k. 17.

638 D. Kołodziejczyk, The Ottoman Survey, s. 88.

${ }^{639}$ BZNiO: sygn. 1359/II, Akta sądu [...] w Stanisławowie 1681-1689, s. 435.

${ }^{640}$ ЦДІАУ: f. 39, op. 1, spr. 42, k. 256-256v.

${ }^{641}$ Ibidem, spr. 158, k. 185.

${ }^{642}$ Ibidem, spr. 41, k. 244.

${ }^{643}$ Ibidem, spr. 42, k. 285.

644 Ibidem, spr. 41, k. 41.

${ }^{645}$ Ibidem, spr. 158, k. 191.

${ }^{646}$ D. Kołodziejczyk, The Ottoman Survey, s. 89.

${ }^{647}$ FKiDOP: sygn. 18/226, Inwentarz i księga wydatków, s. 2.

${ }^{648}$ Ibidem, sygn. 9/36, Liber defunctorum parochianorum Stanislanoviensium Armenorum [1715-1829], s. 13. 
wybudowano kościół w Stanisławowie), matka czworga dzieci. Druga żona - Maria (1694-1744), wdowa, z którą ożenił się w Stanisławowie w 1722 roku i miał z nią pięcioro dzieci. Rajca od 1722 roku $^{649}$ do 1734 roku, marszałek. Pochowany w Stanisławowie.

Jakub Torosowicz - syn Torosa Bogdanowicza (zob.) i Kirkorówny, w 1723 roku ożenił się w Stanisławowie z Zofią Owanisowiczówna Karakaszówną (zob.) i miał z nią siedmioro dzieci.

Krzysztof (Chaczko) Torosowicz - możliwe, że syn Torosa Bogdanowicza (zob.) i Kirkorówny, pojawiał się w sądzie stanisławowskim w 1693 roku $^{650}$.

Zachariasz (Zadik) Torosowicz († przed 1739 w Jassach) - syn Torosa Bogdanowicza (zob.) i Kirkorówny, w 1717 roku ożenił się w Stanisławowie z Rozalią (ur. przed 1690, † 1768), córką Sahaga Abrahamowicza, szmuklerza ${ }^{651}$, z którą miał córkę.

Zarug Torosowicz - możliwe, że syn Torosa Bogdanowicza (zob.) i Kirkorówny, kleryk $(1719)^{652}$, ksiądz wikariusz w Stanisławowie (1722-1723).

189. Krzysztof Torosowicz Karakasz (Kierekięszowicz) - wnuk Owanesa Karakasza (Charachasza), jerespochana ${ }^{653}$. Syn Hanusowiczówny (córki Hanusa, siostry Zachariasza Hanusowicza Hrapacza Romaszkiewicza) ${ }^{654}$ i Torosa Iwanisowicza (Owanesowicza) Karakasza (Charachasz, Kierekasz). Krzysztof był bratem Marty Amirowiczowej (żony Jana Takwora) ${ }^{655}$, pojawiał się w sądzie w latach $1653^{656}$ i $1661^{657}$. W Sozopolu reprezentował Radę Czterdziestu Mężów (Dokument nr 3 ) i występował bez funkcji (Dokument nr 5), w Filibe (Dokument nr 11) i ponownie jako przedstawiciel Rady Czterdziestu Mężów (Dokument nr 12).

400. Zachariasz Toszka (Tośka) - w Filibe, w 1676 roku, jako przedstawiciel Rady Czterdziestu Mężów, był świadkiem rozliczania delegatów do Porty (Dokument nr 12).

Jan (Jasko) Tugalbejowicz - w 1654 roku notowany w sądzie ${ }^{658}$, w 1676 roku był w Filibe przy rozliczaniu delegacji do Porty (Dokument nr 12).

401. Tumanicha - w Filibe, w 1676 roku, pieniądze za nią odebrał Megerdycz Kirkorowicz (zob.).

Grzegorz Tumanowicz - możliwe, że syn Tumana Serhiowicza; w 1676 roku w Filibe odebrał pieniądze ,imie[niem] Panię Owakowiczowey [zob.]” (Dokument nr 13). Możliwe, że ten sam mieszkał w Jazłowcu w 1684 roku $^{659}$.

402. Mikołaj (Mitkus) Tumanowicz - możliwe, że syn Tumana Serhiowicza; mąż Katarzyny (Manuszak); w 1708 roku w Horodence urodziły się im bliźniaczki, Anna i Marianna.

${ }^{649}$ B. Czart.: sygn. 3543 IV, k. 107.

${ }^{650}$ BZNiO: sygn. 1590/II, Akta sądu [...] w Stanisławowie z lat 1692-1702, s. 112-113.

${ }^{651}$ FKiDOP: sygn. 9/39, Księga małżeństw 1700-1813, k. 2 v-3.

652 B. Czart.: sygn. 3543 IV, k. 85.

653 А. Н. Гаркавец, Кыпчакское письменное наследие, s. 953.

${ }^{654}$ ЦДІАУ: f. 39, op. 1, spr. 158, k. 37-37v.

655 Ibidem, spr. 41, k. 54.

${ }^{656}$ Ibidem, k. 35v.

${ }^{657}$ Ibidem, spr. 42, k. 217.

658 Ibidem, spr. 41, k. 74-74v.

659 BZNiO: sygn. 1732/II, Protocollum actorum consistorii, k. 68. 
406. Krzysztof Wartanowicz - pasierb Bobryka Iwanisowicza, brat przyrodni Jana Bobrykiewicza (zob.) (1653) ${ }^{660}$ i Augustynowej Isajowiczowej, mąż siostry Zachariasza Krzysztofowicza (zob.) (1662) ${ }^{661}$. W 1676 roku w Filibe - przedstawiciel Rady Czterdziestu Mężów (Dokument nr 11, nr 16).

409. Jakub Warteresiewicz (Warteresowicz) (1655 - 20 października 1732) - jako diakon przebywał we Lwowie w 1677 roku $^{662}$.

Jan Warteresowicz - „kompromisarz” w sprawie z 1650 roku ${ }^{663}$; jako przedstawiciel Rady Czterdziestu Mężów w 1676 roku w Filibe był przy rozliczaniu delegacji do Porty (Dokument nr 12).

Jan Dadumowicz Warteresowicz († po 1739) - możliwe, że syn Warteresa Tatumowicza (Dadumowicza) (zob. „Lehahayer”, 6, s. 62), mieszkaniec Stanisławowa. Mąż Katarzyny, z którą miał dzieci: Marię (ur. 1724), Warteresa Stefana (ur. 1726), Annę Justynę (ur. 1728), Justynę Helenę (ur. 1730). Potem mąż Heleny (1739) ${ }^{664}$.

411. Warteres Warteresowicz († po 1676) ${ }^{665}$ - przyrodni brat Szymona Krzysztofowicza (zob.), w sądzie w różnym charakterze pojawiał się w latach: 1652, 1654-1657, $1660^{666}$.

131. Krzysztof Warteris Warteresowicz Dryngaczowicz (Dryngaczyk) $(\dagger 1676 / 1682)$ prawdopodobnie syn Warteresa Dryngacza Serhiowicza i Gertrudy ${ }^{667}$, pierwszy mąż Zofii / Marianny 2v. Balewiczowej (zob.) (nie Hanesowiczowej, jak podałam w „Lehahayer”, 6), ojciec Bogdana Krzysztofowicza (zob.). W Stanisławowie właściciel domu i gruntów między kamienicą Donowaka a domem Abrahama, zięcia Sośnichy ${ }^{668}$. W 1675 roku w Sozopolu występował jako przedstawiciel Rady Czterdziestu Mężów (Dokument nr 3), oddano mu dług (Dokument nr 4), powierzono mu skrzyneczkę z przedmiotami kościelnymi (Dokument nr 5), był świadkiem rozliczenia delegatów do Adrianopola (Dokument nr 6). W Filibe był przedstawicielem Rady Czterdziestu Mężów (Dokument nr 7) (por. też Krzysztof Warteresowicz, ,Lehahayer", 6, s. 64). Możliwe, że tożsamy z Krzysztofem Warteresowiczem, ojcem Anny Pierzadowiczowej, przysięgłym $\left(1647^{669}, 1651\right)$ i jerespochanem $(1651)^{670}$.

304. Kirkor [Warteresowicz] Nimicki - bardzo dużo spraw z jego udziałem spisanych w języku polskim może świadczyć, że nie znał ormiańskiego (stąd: nimic, tj. Polak, polskojęzyczny), w sądzie notowany był od $1651^{671}$ do 1663 roku. W 1675 roku w Sozopolu był przedstawicielem Rady Czterdziestu Mężów (Dokument nr 3), podobnie - w 1676 roku w Filibe (Dokument nr 11, nr 12).

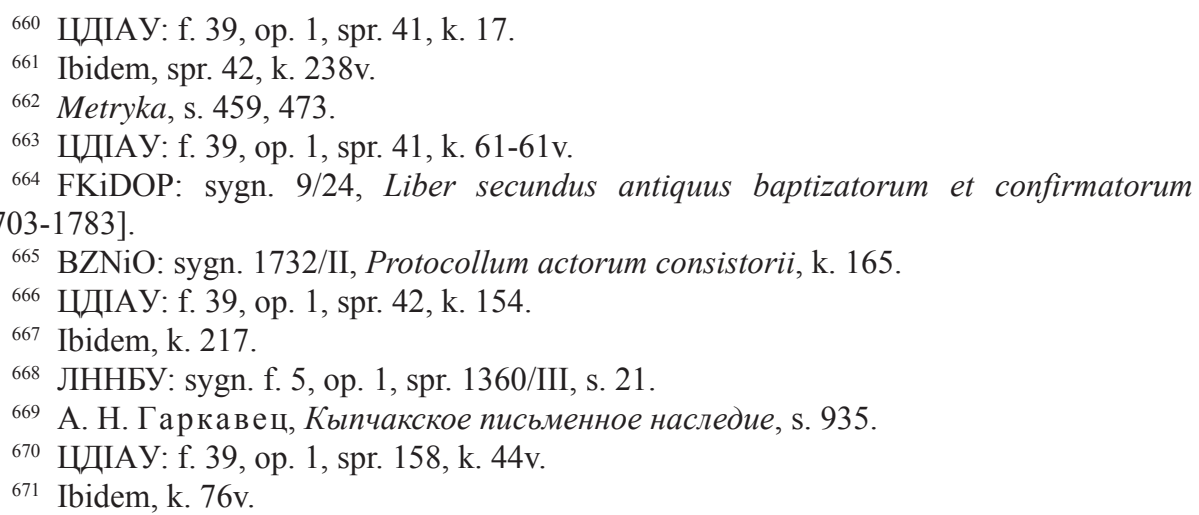


423. Zofia Nigołówna [Mikołajówna] - szpitalna (Dokument nr 13).

420. [Marencja Zachariaszowiczowa? ${ }^{672}$ ] Zachariaszowa Wilczkowa (Dokument nr 13).

Hanna Zadikówna Witelnikówna (ur. 15 września 1678 we Lwowie) - córka Zadika (Zachariasza) Witelnika ${ }^{673}$ (zob. „Lehahayer”, 6, s. 64).

Murad Zachariaszewicz - syn ks. Zachariasza ${ }^{674}$, jego siostra była żoną ks. Nersesa Hołubowicza (zob.), jego drugą żoną była Anastazja Dermichałowiczówna, siostra ks. Michała Dermichałowicza (zob.) $(1655)^{675}$. Był pisarzem $(1629,1632)^{676}$, wójtem (1646-1648 $\left.{ }^{677}\right)$, jerespochanem $\left(1651^{678}\right)$, namiestnikiem ${ }^{679}$, przysięgłym od 1655 do 1666 roku $^{680}$. Miał dom „na cmyntarzu Panny Naswiętszey Religiey Ormiańskiej będącym" (1656) ${ }^{681}$.

419. Zachariasz Zachariaszewicz (Zadykiewicz) Browar - ksiądz, w sądzie jako świadek pojawił się w 1656 roku $^{682}$. Możliwe, że tożsamy z ks. Zachariaszem Owanisem Zadykiewiczem (Owanesowiczem), który był w Sozopolu w 1675 roku (Dokument nr 2, nr 5) i rok później w Filibe (Dokument nr 11, nr 12, nr 16).

Mikołaj Zachariaszewicz Browarczyk - brat Serhija i ks. Zachariasza Zachariaszewiczów (zob. „Lehahayer”, 6, s. 65), mąż Róży (zob.) (1659) ${ }^{683}$, kupiec (1656) ${ }^{684}$, prawdopodobnie tożsamy z kupcem lwowskim, który stawał przed sądem w Stanisławowie $(1683)^{685}$.

418. Serhij Zachariaszewicz Browar (por. „Lehahayer”, 6, s. 65) - brat ks. Zachariasza i Mikołaja Zachariaszewiczów, kupiec w Zamościu, czynny też w Piotrkowie i Lublinie, żonaty z Rozalią Łukasiewiczówną, Ormianką zamojską, ojciec Krzysztofa $\left(†\right.$ 1690/1691), który utonął pod Lwowem ${ }^{686}$, Heleny Kistesterowiczowej († 1680), zamordowanej w Zamościu, i Katarzyny Głowackiej ${ }^{687}$.

Zachariaszewiczowa - wdowa po Der Zachariaszu Zachariaszewiczu (,popadia”) procesowała się w 1702 roku z bratową, wdową po Mikołaju Browarze, o nieruchomości w Kamieńcu Podolskim ${ }^{688}$.

672 Ibidem, spr. 42 , k. 62v-63.

${ }^{673}$ Metryka, s. 477.

674 А. Н. Гаркавец, Кыпчакское письменное наследие, s. 925.

675 ЦДІАУ: f. 39, op. 1, spr. 41, k. 163.

676 А. Н. Гаркавец, Кыпчакское письменное наследие, s. 925-926.

677 Ibidem, s. 934-935, 939.

${ }^{678}$ ЦДІАУ: f. 39, op. 1, spr. 158, k. 19v.

679 Ibidem, spr. 41, k. 111.

${ }^{680}$ S. Krzyżanowski, Pamiatki polskie, s. 41.

681 ЦДІАУ: f. 39, op. 1, spr. 41, k. 215v.

${ }^{682}$ Ibidem, spr. 42, k. 220v.

683 ЦДІАУ: f. 39, op. 1, spr. 42, k. 104.

${ }^{684}$ Ibidem, spr. 41, k. 212v.

685 BZNiO: sygn. 1359/II, Akta sądu [...] w Stanisławowie 1681-1689, s. 211-213.

${ }^{686}$ Metryka, s. 525. Por. artykuł M. Ł. Majewskiego, Karta ze stosunków rodzinnych Ormian zamojskich: morderstwo Heleny Kistesterowiczowej (1680) w niniejszym roczniku „Lehahayer”.

${ }^{687}$ Por. artykuł M. Ł. Majewskiego w niniejszym roczniku „Lehahayer”.

${ }^{688}$ ЦДІАУ: f. 39, op. 1, spr. 46, k. 37- 37v. 
Anastazja Dermichałowiczówna Zachariaszewiczowa - siostra ks. Michała Dermichałowicza (zob.), druga żona Murada (1655).

Róża Mitkówna Zachariaszewiczowa Browarczykowa (por. „Lehahayer”, 6, s. 29, hasło: Browarczykowa) - żona Mikołaja (zob.) $(1659)^{689}$.

\section{Bibliografia}

\section{Źródła archiwalne}

Archiwum Fundacji Kultury i Dziedzictwa Ormian Polskich w Warszawie: sygn. 9/3, Anno D[om]ni 1707 Metrica Ecclesiae Horodecensis Armenae [1707-1793]; sygn. 9/24, Liber secundus antiquus baptizatorum et confirmatorum [1703-1783]; sygn. 9/36, Liber defunctorum Parochianorum Stanislauoviensium Armenorum [1715-1829]; sygn. 9/39, Księga małżeństw 1700-1813 (https://szukajwarchiwach. pl/345\#tabZasoby); sygn. 18/226, Inwentarz i księga wydatków K[ościoła] Pa[arafialnego] Ormiańskiego w Stanisławowie XVIII-XIX

Archiwum Główne Akt Dawnych w Warszawie: Księgi metrykalne i akta parafii i gmin różnych wyznań i obrządków (Ormianie, Autokefaliczna Cerkiew Prawosławna, Baptyści, Mennonici, Ewangeliczni Chrześcijanie) z terenów tzw. zabużańskich; sygn. 456/1, Liber metricarum. Ecclesia Armena Zloczoviensis (http://agadd.home. net.pl/metrykalia/456/sygn.\%201/indeks.htm)

Archiwum Narodowe w Krakowie: Archiwum Sanguszków Podhoreckie II, sygn. Podh II 165, Księga wójtowska z Jazłowca 1648-1669

Biblioteka Książąt Czartoryskich (Muzeum Narodowe) w Krakowie: sygn. 3543 IV, Akta zaręczynowe i małżeńskie parafii obrządku ormiańskokatolickiego w Stanisławowie z lat 1693-1784 (tłumaczenie na język polski: http://www.archiwum.ormianie.pl/archiwuma.php?ida=15\&id=83862\&ik=1)

Biblioteka Narodowa: sygn. Rps Akc. 12904, Wygnańcy ormiańscy Kamieńca Podolskiego w Turcji (1675-1677). (Regestra wywiezionych z Kamieńca aparatów kościelnych i ich stopniowa sprzedaz)

Biblioteka Zakładu Narodowego im. Ossolińskich we Wrocławiu: sygn. 1359/II, Akta sądu prawa uprzywilejowanego ormiańskiego w Stanisławowie 1681-1689; sygn. 1590/II, Akta sądu ormiańskiego w Stanisławowie z lat 1692-1702; sygn. 1732/II, Protocollum actorum consistorii archiep[iscop]atus Leopolien[sis] nationis Armenae tam sub administratione Re[vere]nd[issi]mi D[omi]ni Deodati Nersessovicii episcopi Traianopolitanensis quam sub felici introductione Ilustr[issi]mi ac Re[vere]nd[issi] mi D[omi]ni Vartani Hunaniani Dei et Ap[osto]licae Sedis Gratia archiep[iscop]i Leopoliensis nationis eiusdem Armenae formatum [1684-1699]

[Centralnyj] Центральний державний історичний архів України, м. Київ: księgi sądu ormiańskiego Kamieńca Podolskiego, sygn. f. 39, op. 1, spr. 158, spr. 41, spr. 42

[Centralnyj] Центральний державний історичний архів України, м. Львів: sygn. f. 52, op. 2, spr. 531, Acta iudicii civilis Armenorum, s. 1538-1551, 1556-1563, 1569-1572

[Lwiwśka] Львівська національна наукова бібліотека України імені В. Стефаника: sygn. f. 5, op. 1: spr. 1360/III Księga Akt Orm. No 3ti zaczęto 1703ciego Roku kaczy się 1709; spr. 1485, Akta sądowe Ormian w Jazłowcu (1669-1672)

${ }^{689}$ Ibidem: f. 39, op. 1, spr. 42, k. 104-104v. 
[Nacionalnyj] Национальный исторический архив Беларуси в г. Минске: ф. 1807, оп. 1, од. 1, Akta sądu ormiańskiego w Zamościu 1660-1668

\section{Źródła drukowane}

Album armorum nobilium Regni Poloniae XV-XVIII saec. Herby nobilitacji i indygenatów XV-XVIII w., wstęp, opracowanie i edycja B. Trelińska, Lublin 2001

Album civium Leopoliensium. Rejestry przyjęć do prawa miejskiego we Lwowie 13881783, 1, wyd. A. Janeczek, Poznań 2005

[Garkawec A. N.] Гаркавец А. Н., Кыпчакское письменное наследие, Каталоги и тексты памятников армянским письмом, t. Украина, Алматы 2002, s. 871-954

Kołodziejczyk D., The Ottoman Survey Register of Podolia (ca. 1681). Defter-i Mufassal-i Eyalet-i Kamaniçe, 1, Harvard 2004

Metryka katedry ormiańskiej we Lwowie za lata 1635-1732 w opracowaniu Krzysztofa Stopki (część kipczacka) i Marcina Łukasza Majewskiego (część polska i łacińska), seria: Pomniki dziejowe Ormian polskich, 3, Kraków 2020

Roszka S., Chronologia, czyli roczniki kościelne, seria: Pomniki dziejowe Ormian polskich (w przygotowaniu)

Woliński J., Materjały do rokowań polsko-tureckich r. 1676, „Przegląd Historyczny”, 29, 1930-1931, 2, s. 382-413

Woliński J., Przyczynki źródtowe do kampanii 1674 r., „Przegląd Historyczno-Wojskowy", 6, 1933, s. 81-101

\section{Opracowania}

Agopsowicz M., Ormianie kamienieccy w ostatniej ćwierci XVII wieku - próba rekonstrukcji spisu imiennego, „Lehahayer”, 6, 2019, s. 5-69, https://doi.org/10.12797/ LH.06.2019.06.01

Barącz S., Pamiątki miasta Stanisławowa, Lwów 1858

Barącz S., Pamiętnik dziejów polskich, Lwów 1855

Barącz S., Żywoty sławnych Ormian w Polsce, Lwów 1856

[Grigorian W.] Григорян В., История армянских колоний Украины и Польши (армяне Подолии), Ереван 1980

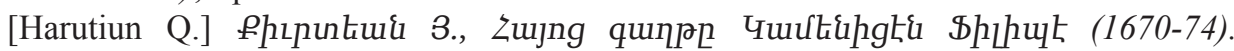

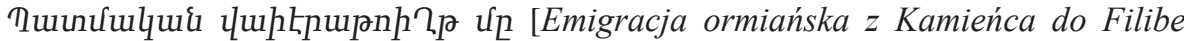
(1670-74). Zabytek historyczny], „Fuquuultuu” [Pazmaveb], 8-9, 1927

Kopczyński J., Struktura i finanse gminy ormiańskiej we Lwowie w świetle rękopisu „Dzieje Ormian lwowskich od r. 1649 aż do r. 1713”, „Lehahayer”, 4, 2017, s. 5-69, https://doi.org/10.12797/LH.04.2017.04.01

Nagielski M., Romaszkiewicz (Romaszkiewic, Romaszkowicz) Jan bądź Piotr, w: Polski słownik biograficzny, 31, Wrocław-Warszawa-Kraków 1988, s. 620-621

Niesiecki K., Herbarz polski, wyd. J. N. Bobrowicz, 1-10, Lipsk 1841

Stopka K., „Jako ojczyc prawdziwy ojczyzne swa miła chcac tym lepiej przyozdobić”. Historia dział Michnowskich niegdyś Kamieniec Podolski broniacych, w: Amicissima. Studia Magdalenae Piwocka oblata, Cracoviae 2010, s. 245-254

Stopka K., Wykaz duchowieństwa ormiańskiego w Polsce (elektroniczna baza danych)

Tomaszewski M., Działalność dyplomatyczna i agenturalna Jana badź Piotra Romaszkiewicza w latach 1648-1655, „Przegląd Orientalistyczny” 2014, 3/4, s. 149-156 
Zaleski T., Stownik biograficzny duchownych ormiańskokatolickich oraz duchownych rzymskokatolickich pochodzenia ormiańskiego w Polsce w latach 1750-2000, Kraków 2001

Monika Agopsowicz, Kamieniec Armenians in the last quarter of the 17th century. Supplementation of the name list on the basis of subsequent sources

Abstract: The author uses subsequent historical sources to supplement the data about Armenians living in Kamieniec Podolski (Kamianets-Podilskyi) before the Turkish invasion in 1672 and soon after regaining the town by Poland in 1700. These sources include: book of the Armenian court of Kamieniec Podolski from 1651-1663; registers of church apparatus taken away from Kamieniec and their gradual sales; Turkish censuses of the people of Kamieniec Podolski, including Armenians, from 1681 .

Keywords: Polish Armenians, Kamieniec Podolski (Kamianets-Podilskyi), Filibe (Płowdiw), Sozopol, Andrzej Modrzejowski, Jan Romaszkiewicz, Polish-Turkish relations, 17 th century

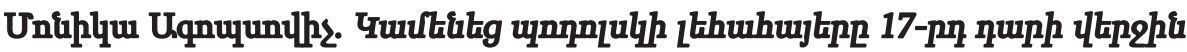

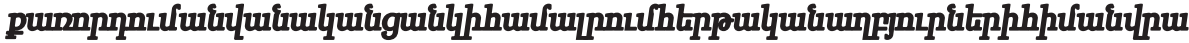

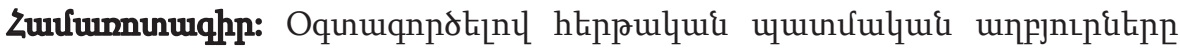

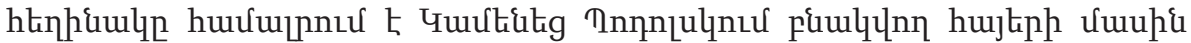

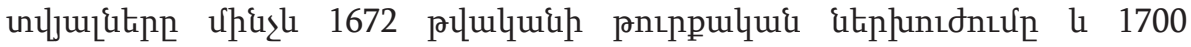

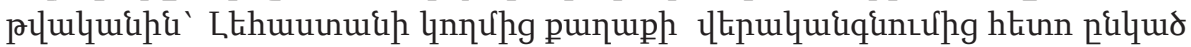

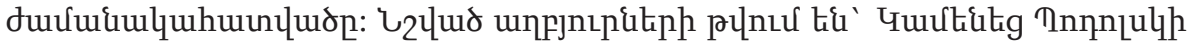

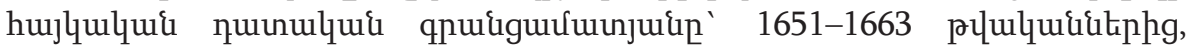

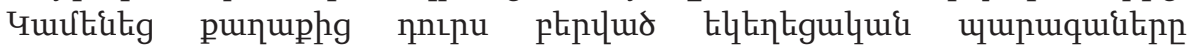

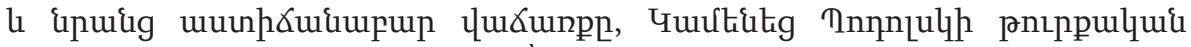

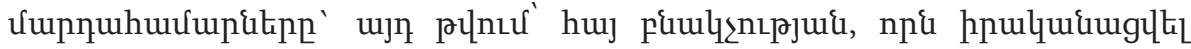
Ł 1681 plulquihi :

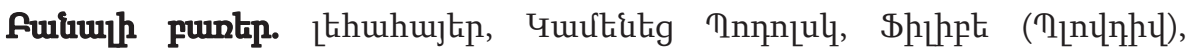

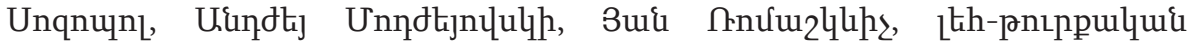

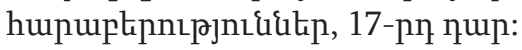

